\title{
A Middle Pennsylvanian (Bolsovian) peat-forming forest preserved in situ in volcanic ash of the Whetstone Horizon in the Radnice Basin, Czech Republic
}

Opluštil, Stanislav; Pšenicka, Josef; Libertín, Milan; Bashforth, Arden Roy; Šimunek, Zbynek; Drábková, Jana; Dašková, Jirina

Published in:

Review of Palaeobotany and Palynology

Publication date:

2009

Document version

Publisher's PDF, also known as Version of record

Citation for published version (APA):

Opluštil, S., Pšenicka, J., Libertín, M., Bashforth, A. R., Šimunek, Z., Drábková, J., \& Dašková, J. (2009). A Middle Pennsylvanian (Bolsovian) peat-forming forest preserved in situ in volcanic ash of the Whetstone Horizon in the Radnice Basin, Czech Republic. Review of Palaeobotany and Palynology, 155(3-4), 234-274. 


\title{
A Middle Pennsylvanian (Bolsovian) peat-forming forest preserved in situ in volcanic ash of the Whetstone Horizon in the Radnice Basin, Czech Republic
}

\author{
Stanislav Opluštil a,* ${ }^{\mathrm{a}}$, Josef Pšenička ${ }^{\mathrm{b}}$, Milan Libertín ${ }^{\mathrm{c}}$, Arden R. Bashforth ${ }^{\mathrm{d}, 1}$, Zbyněk Šimůnek ${ }^{\mathrm{e}}$, \\ Jana Drábková ${ }^{\mathrm{e}}$, Jiřina Dašková ${ }^{\mathrm{f}}$ \\ a Charles University in Prague, Faculty of Sciences, Albertov 6, 12843 Praha 2, Czech Republic \\ ${ }^{\mathrm{b}}$ Palaeontology Department, West Bohemian Museum in Plzeň, Kopeckého sady 2, 30136 Plzeñ, Czech Republic \\ ' National Museum, Václavské náměstí 68, 11579 Praha 1, Czech Republic \\ d Department of Earth Sciences, Dalhousie University, Halifax, Nova Scotia, Canada B3H 3J5 \\ e Czech Geological Survey, Klárov 131/3, 11821 Praha 1, Czech Republic \\ ${ }^{\mathrm{f}}$ Department of Palaeobiology and Palaeoecology, Institute of Geology v.vi.., Academy of Sciences of the Czech Republic, Rozvojová 269, 16500 Praha 6, Czech Republic
}

\section{A R T I C L E I N F O}

\section{Article history:}

Received 18 August 2008

Received in revised form 27 February 2009

Accepted 16 March 2009

Available online 20 March 2009

\section{Keywords}

Pennsylvanian

tuff

in situ

plant taphonomy

palaeoecology

peat-forming mires

\begin{abstract}
A B S T R A C T
The precursory mire of the Middle Pennsylvanian (Bolsovian) Lower Radnice Coal was buried in situ by volcanic ash, preserving the taxonomic composition, spatial distribution, vertical stratification, and synecology of this peat-forming ecosystem in extraordinary detail. Plant fossil remains represent the preeruption vegetation of the swamp, which resulted from accumulation of peat in a high-ash, planar (rheotrophic) mire situated in a narrow palaeovalley containing an active fluvial system. A tuff bed (the Bělka) at the base of the volcaniclastic Whetstone Horizon was exposed in two contiguous excavations over an area of $50 \mathrm{~m}^{2}$ in the Radnice Basin of western Bohemia, Czech Republic. Twenty-seven morphotaxa were identified, representing 20 whole-plant species with a wide variety of growth forms. The canopy of the peatforming community was dominated by Cordaites borassifolius trees together with the arborescent lycopsid "Lepidodendron" (= Paralycopodites), whereas Lepidophloios cf. acerosus was subdominant. Evidence suggests that the laterally extensive "crowns" of these arborescent lycopsids would have overlapped during the final phase of their life cycles, but differences in the height of tree species resulted in a complex and vertically variable canopy interrupted by randomly distributed gaps. The understorey was dominated by medullosan pteridosperms and marattialean tree ferns, whereas zygopterid ferns and sphenophylls comprised the bulk of the ground cover. In comparison with the canopy, understorey and ground cover species were less abundant and patchier in distribution, with almost complete absence beneath the deep shade of $C$. borassifolius trees. Lianas that entwined arborescent trees were an important component of the peat-forming forest. Three lyginopterid pteridosperm species along with a sphenophyll had a lianescent habit based on their close association with upright or prone lycopsid trunks and "canopy" branches. Species richness in the swamp superficially appears low. However, considering the small area of excavation, along with the higher diversity known from the same tuff bed in the adjacent, former opencast Ovčín Mine, it appears that species richness in the forest was comparable to some of the less diverse Westphalian peat-forming swamps in the U.S.A. The Lower Radnice mire vegetation was compositionally homogeneous, but had a heterogeneous distribution with patchiness occurring at a very fine scale. The preserved plant assemblage most resembles mires dominated by medullosan pteridosperms and Paralycopodites described from upper Westphalian coal balls in the U.S.A., which were characterised by high diversity in all storeys and involved plants centred in high-ash peat-forming swamps.
\end{abstract}

(c) 2009 Elsevier B.V. All rights reserved.

\section{Introduction}

The Pennsylvanian is one of the main coal-forming periods in Earth history. During this time, peat-forming forests covered vast

\footnotetext{
* Corresponding author.

E-mail address: oplustil@natur.cuni.cz (S. Opluštil).

1 Current address: Geological Museum, Natural History Museum of Denmark, University of Copenhagen, Øster Voldgade 5-7, 1350 Copenhagen K, Denmark.
}

areas of paralic lowland and intramontane settings along the palaeoequator, resulting in large coalfields scattered through parts of North America, Europe and China. Spore-producing plants dominated these forests, with the arborescent lycopsids contributing the majority of biomass to accumulating peats during the Westphalian (Early and Middle Pennsylvanian), and the filicopsids and sphenopsids rising to prominence in the Stephanian (Late Pennsylvanian) (Phillips and Peppers, 1984; Phillips et al., 1985). Seedbearing plants, represented by the pteridosperms and cordaitaleans, 
were common components of peat-forming mires, but generally contributed little biomass to peats. Nonetheless, the cordaitaleans were an important element in some Middle Pennsylvanian swamps (Phillips and Peppers, 1984; Costanza, 1985; Raymond, 1988).
Although some of these plant groups are extant, their modern representatives are hardly comparable with those of Pennsylvanian times because of differences in their habit, anatomy and ecological demands (Cleal, 1991).

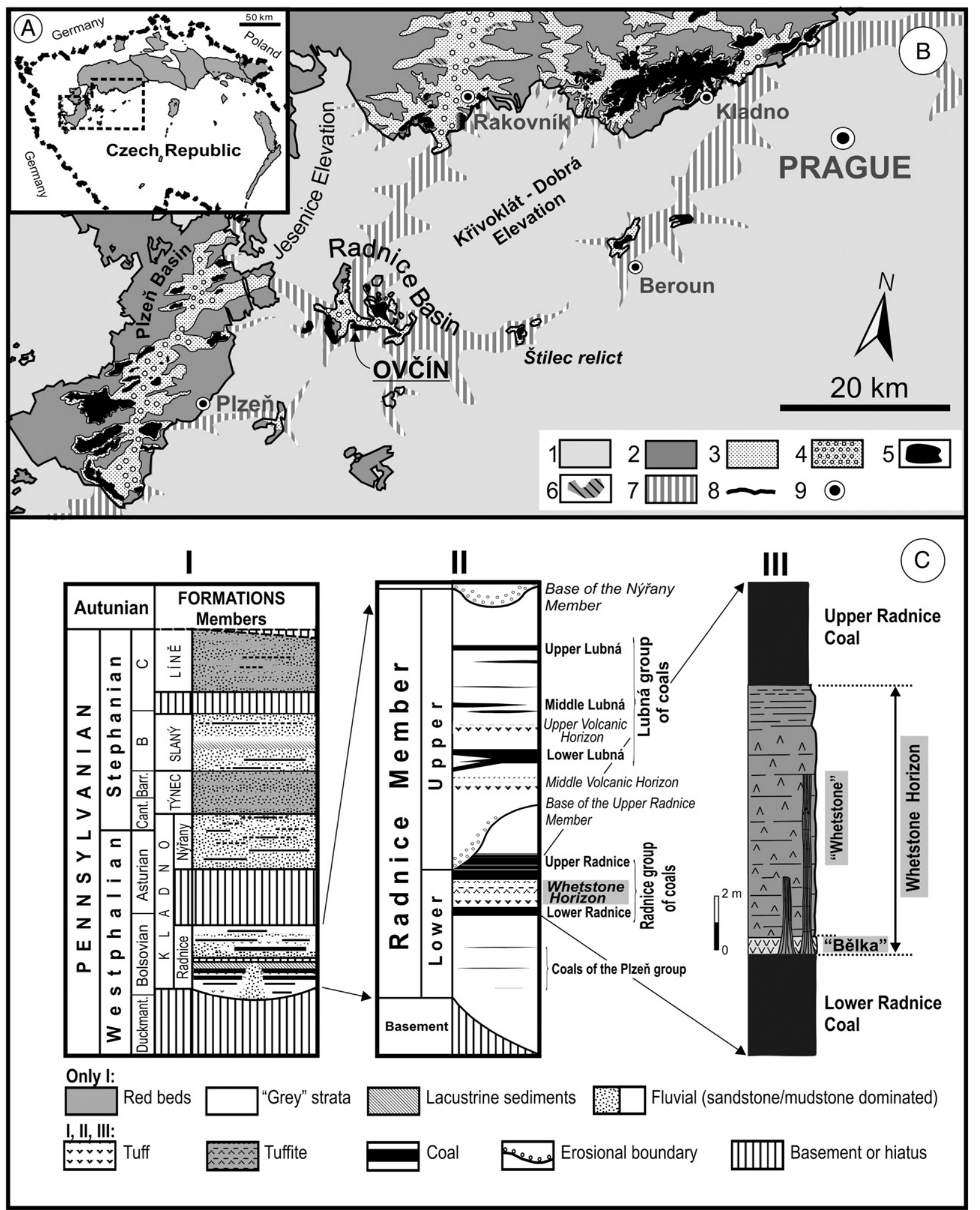

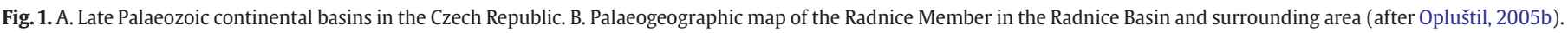

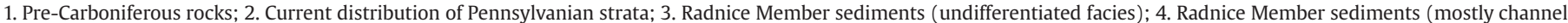

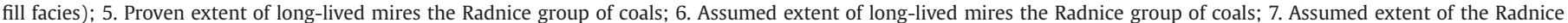

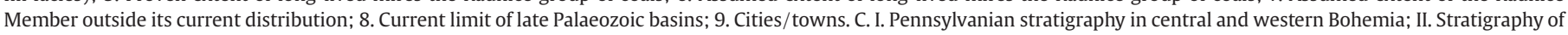
the Radnice Member; III. Radnice group of coals and the Whetstone Horizon in the opencast Ovčín Mine. 
Fossilised floral remains associated with peat-forming environments are almost invariably fragments of isolated plant organs, with disaggregation of the original living plant resulting from a variety of taphonomic processes (Gastaldo, 1988; Spicer, 1989; Bateman, 1991). Finding large, articulate portions of a plant, especially one of tree habit, occurs only under exceptional circumstances (e.g., Thomas and Watson, 1976; Wnuk and Pfefferkorn, 1984; Wnuk, 1985; Rößler, 2001). For this reason, reconstructions of these extinct plants are based on the presumed correlation of isolated organs, although many uncertainties remain despite two centuries of palaeobotanical investigations of Carboniferous floras.

Similar obstacles are met when studying these forests as palaeoecosystems, as their structure and composition are always more or less biased due to these same taphonomic processes. Ecologically, Carboniferous wetland vegetation can be broadly subdivided into that growing on clastic substrates, and that inhabiting peat substrates of mires. The flora of clastic substrates is well known from compressions in sedimentary rocks accompanying coal seams, and their habitat preferences are reasonably well understood (e.g., Scott, 1978, 1979; Gastaldo, 1987). Conversely, peat-forming floras can be studied from various types of fossil records. In some cases, finegrained strata that slowly accumulated above coal seams contain plant remains (i.e., roof-shale floras) that represent the last inhabitants of the mire (Type B assemblage of Gastaldo et al., 1995). Another source of data is coal balls, which are diagenetic concretions that formed within peat prior to its compaction, thus preserving the anatomical details of plant tissues in extraordinary detail by permineralisation
(Scott and Rex, 1985; Scott et al., 1996). Further information on the composition of peat-forming vegetation can be deduced from the spectrum of palynomorphs recovered from low to medium rank coals. However, biases in the absolute abundance of palynomorphs can be introduced by maceration techniques, their transportability over wide areas, and the fact that the quantity of spores or pollen produced by different taxa varied greatly (Willard, 1993). Although each of these areas of expertise has made significant contributions to a broader understanding of Pennsylvanian peat-forming ecosystems, they sometimes rely on data gathered from samples that may be both time-averaged and taphonomically filtered (Behrensmeyer et al., 2000). For example, several generations of swamp-dwelling plants may be represented in a single coal ball or a coal sample macerated for palynomorphs, whereas even a thin roof-shale interval can contain plant matter derived from both the underlying mire and plant communities that recolonised the area after its demise. Accordingly, these data do not necessarily record an instantaneous snapshot of the mire vegetation.

Greater fidelity in the spatial and compositional structure of Pennsylvanian mires can be achieved when these ecosystems are buried in a geological instant (a $T^{0}$ deposit), effectively fixing the plant relationships in both space and time and removing many of the taphonomic variables. One of the primary mechanisms for producing a $T^{0}$ deposit is a coseismic event, such as an earthquake, that catastrophically drops the swamp surface below the water table or sea level (Type A roof-shale assemblage of Gastaldo et al., 1995). Informative examples of such deposits have

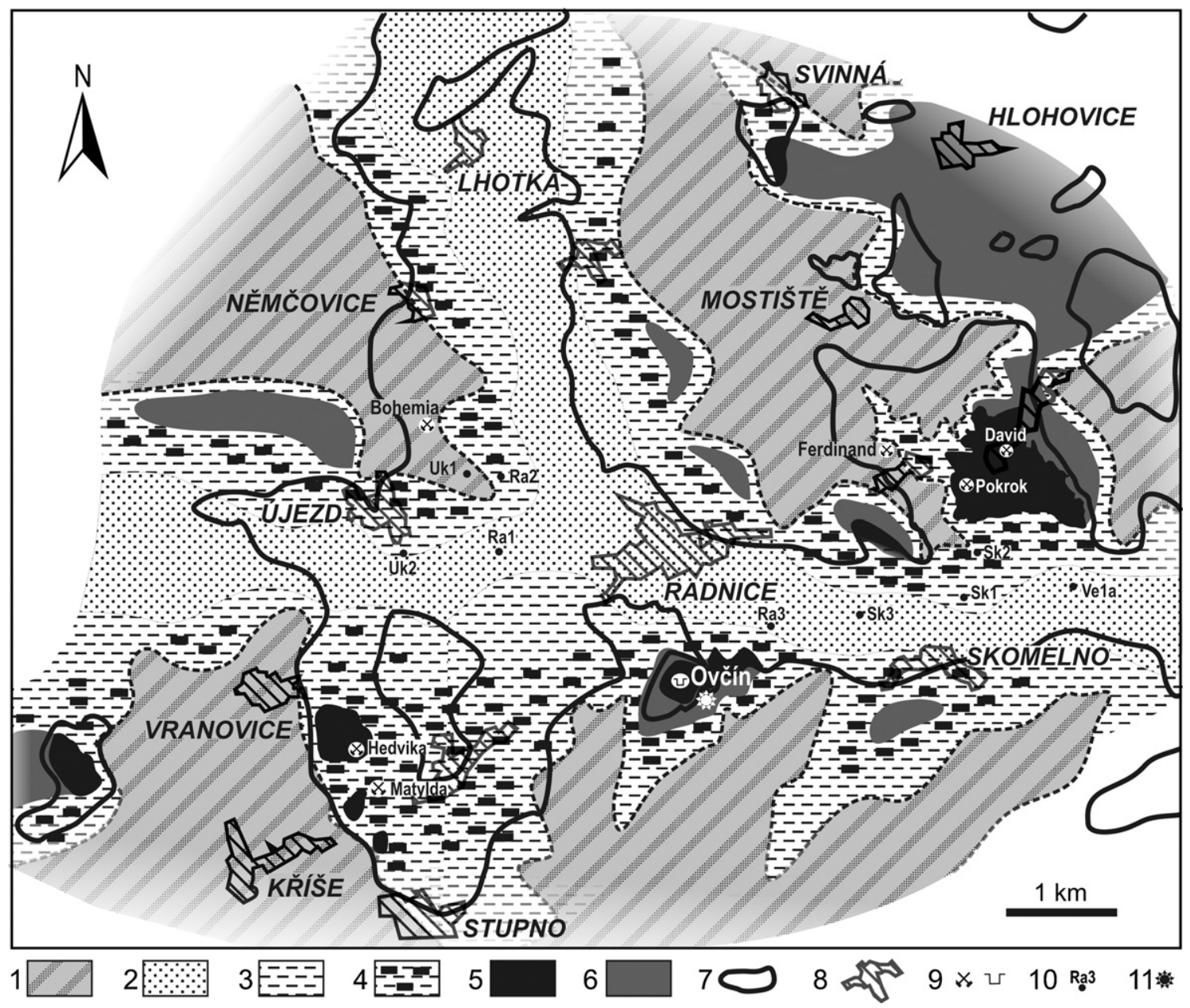

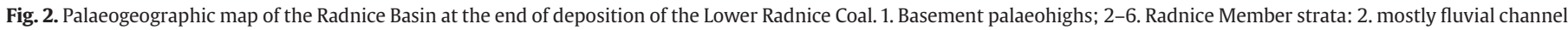

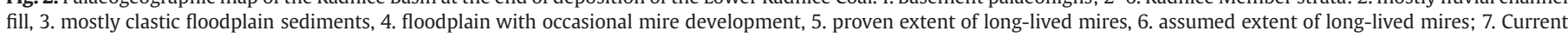
basin margins; 8. Urbanised area; 9. Abandoned underground and opencast mines; 10. Boreholes to the basement; 11. Excavation location. 
recently been documented from Lower Pennsylvanian (Gastaldo et al., 2004a,b) and Middle Pennsylvanian (DiMichele et al., 2007) strata in the U.S.A.

Another excellent opportunity for studying the composition and spatial relationship of different plant types in a peat-forming swamp is presented by fossiliferous tuff beds that directly overlie a coal seam. In such a scenario, volcanic ash falls onto and kills the vegetation in a geological instant, resulting in burial and preservation of the swamp community in its original spatial context. Although volcaniclastic rocks are quite common in many coal basins of North America and Europe, very few of them actually contain identifiable plant remains buried in situ. The absence of fossils could be related to two main factors. Firstly, a minimum thickness of volcanic ash (ca. $10 \mathrm{~cm}$ after compaction, Opluštil et al., 2007) would be required to completely bury small plants near the forest floor, and to damage large, arborescent vegetation due to overloading by ash. Secondly, plant remains within thin ash beds would be prone to penetration and destruction by the dense roots of post-eruption floras.

A spectacular example of a fossil forest buried in a volcanic ash is the early Permian Chemnitz Petrified Forest in Germany (Rößler and Barthel, 1998; Rößler, 2001), where a diversity of plant remains was buried and later permineralized in the volcanic ash of hyperconcentrated pyroclastic flows. Another $T^{0}$ assemblage was recorded by Wagner (1989) from the Puertollano Basin of Spain, where an Upper Pennsylvanian peat-forming ecosystem was preserved in volcanic ash that repeatedly fell on mires dominated by the unusual lycopsid Omphalophloios (Brousmiche-Delcambre et al., 1995). More recently, Pfefferkorn and Wang (2007) briefly documented early Permian plant remains from a tuff bed overlying a coal seam in Inner Mongolia. Finally, a number of fossiliferous tuff beds are associated with Middle Pennsylvanian coal seams in the Czech Republic, and ongoing research continues to strengthen our knowledge of the progression, diversity, density, and synecology of vegetation within these mires (Opluštil et al., 2007; Libertín et al., 2009-this volume).

In this paper, we document a well-preserved Middle Pennsylvanian (Bolsovian) peat-forming plant assemblage from the base of the Whetstone Horizon in the Radnice Basin of western Bohemia, Czech Republic. This volcanic ash deposit buried a rheotropic, high-ash mire - the precursor of the Lower Radnice Coal. The tuff was excavated in an archaeological-style pit down to the level of the underlying coal seam, allowing for a plan (pre-eruption) view of the mire. The fossil flora is preserved in situ $\left(T^{0}\right)$, and provides an exceptional opportunity to reconstruct not only the species composition of the community, but also the structure, distribution, density, and synecological associations of the peat-forming vegetation in detail. Although only $50 \mathrm{~m}^{2}$ of the forest surface was exposed, this paleoecological study represents one of the most detailed descriptions of a Pennsylvanian mire to date, based on a unique data set that could only be obtained in exceptional circumstances from other palaeobotanical sources.

\section{Geological background}

\subsection{Geology and stratigraphy of the Radnice Basin}

The Radnice Basin represents only a small part of a much larger complex of continental basins ranging from western and central to northeastern Bohemia (Fig. 1A, B). The basin-fill of this complex is largely Carboniferous, although Permian and Triassic strata occur locally. In central and western Bohemia, deposits spanning the interval from middle Westphalian (Bolsovian) to upper Stephanian $C$ are divided into four formations based on alternating grey, coalbearing and red, coal-barren strata (Fig. 1C; Weithofer, 1896, 1902; Pešek, 1994). In the Radnice Basin, which is a ca. $20 \mathrm{~km}^{2}$ erosional relict of Carboniferous sediments located south of the main basin complex (Fig. 1B), only the lower part of the Kladno Formation (the Radnice Member) is present. Approximately $200 \mathrm{~m}$ of the Radnice
Member is preserved, and the variable thickness and irregular distribution of the strata reflect deposition in a system of fluvial palaeovalleys (Opluštil, 2005a). Long-lasting mires developed during periods of increased subsidence rate in areas of reduced clastic input (Opluštil, 2005b). Coal seams are concentrated into three groups the Plzeň, Radnice and Lubná (Fig. 1C) - although only the Radnice group of coals occurs in the Radnice Basin. This group comprises the Lower and Upper Radnice coals, which are separated by the widespread volcanogenic Whetstone Horizon (Mašek, 1973). These mires developed in areas protected against high clastic input, either in minor palaeovalleys or along the margins of the main palaeovalley between the active fluvial channel and flanking ridges (Figs. 1B, 2). The Lower Radnice Coal is typically high in ash and contains thin but common sedimentary partings. It was only mined locally due to its poor quality, but where exploited it is between 2 and $5 \mathrm{~m}$ thick. The Upper Radnice Coal is generally more extensive, thicker and of better quality, and in the Radnice Basin reaches up to $14 \mathrm{~m}$ thick with few sedimentary or volcaniclastic partings.

\subsection{The Whetstone Horizon}

In its typical development, the Whetstone Horizon represents a complex of primary volcaniclastics and reworked volcaniclastics mixed with siliciclastic material. This horizon is known from all of the coalfields in central and western Bohemia where the Radnice group of coals was mined, spread over a distance of about $90 \mathrm{~km}$ in a west-east direction (Fig. 1C). The source area is not precisely known, but a northward

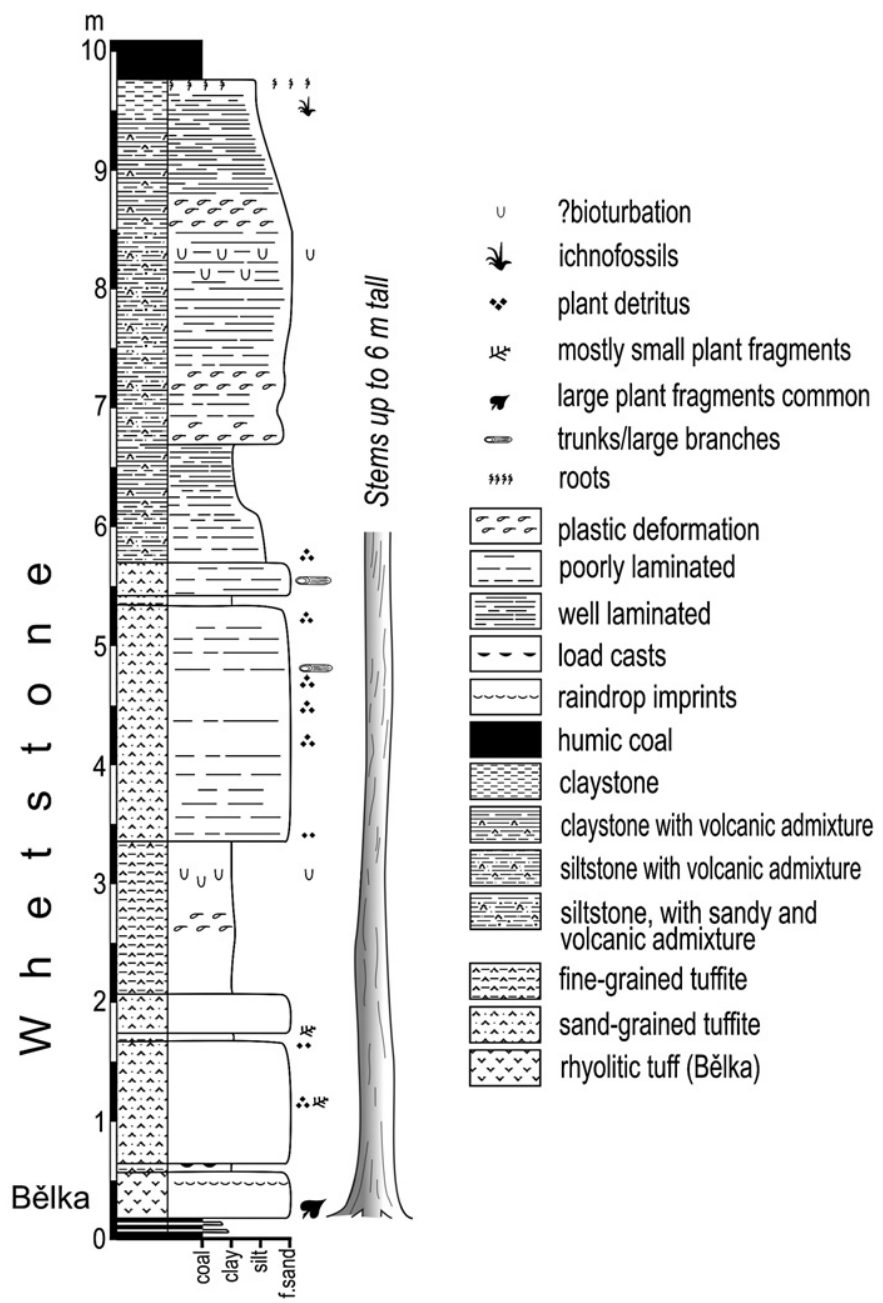

Fig. 3. Architecture of the Whetstone Horizon in the opencast Ovčín Mine (after Drábková, 1986). 
increase in thickness of the basal tuff bed infers a location somewhere in northern Bohemia or in proximity to the Altenberg Caldera around the Czech and German border about $100 \mathrm{~km}$ north of the Radnice Basin (Mašek, 1973; unpublished data). In the Radnice Basin, the Whetstone Horizon is between 2 and $10 \mathrm{~m}$ thick. It consists of ca. 40 to $60 \mathrm{~cm}$ of massive, pale yellow to whitish tuff with sand-sized grains at the base, overlain by a laminated tuffite to tuffaceous mudstone up to $10 \mathrm{~m}$ thick (Fig. 3). The tuff bed at the base, called "Bělka" by miners (translating as "whitish rock"), is dominated by a kaolinite matrix with dispersed entire or fragmentary sanidine and quartz crystals. Vermicular kaolinite crystals are also common, possibly representing biotite pseudomorphs (Mašek, 1973). A thin (few mm) horizon exhibiting raindrop imprints accompanied by poorly developed lapilli occurs in the middle part of the Bělka bed (unpublished data). Radiometric dating of sanidines from the tuff using the ${ }^{40} \mathrm{Ar} /{ }^{39} \mathrm{Ar}$ method yielded results of $309.0 \pm 3.7 \mathrm{Ma}$ (plateau) and 306.9 $\pm 1.5 \mathrm{Ma}$ (total gas) (Hess et al., 1985). The rocks above the Bělka are called "Brousek" (translating as "whetstone") due to the quarrying of these rocks in the past for use as an abrasive. They consist of parallel laminated and locally even ripple cross-laminated tuffites and tuffaceous mudstones with minor silty sandstone, with the volcanic component of the admixture irregularly decreasing in abundance upwards. The Brousek unit reaches over $10 \mathrm{~m}$ thick in some areas, but varies between 8 and $10 \mathrm{~m}$ in the study area, and rooting at the top reflects soil development beneath the overlying Upper Radnice Coal (Fig. 3).

From a genetic point of view, the basal Bělka bed is interpreted as a single volcanic ash fall that buried the entire landscape over an extensive area (Mašek, 1973). Ongoing, unpublished studies of the tuff bed throughout central and western Bohemia suggest that it represents the distal deposits of a high-energy volcanic eruption,

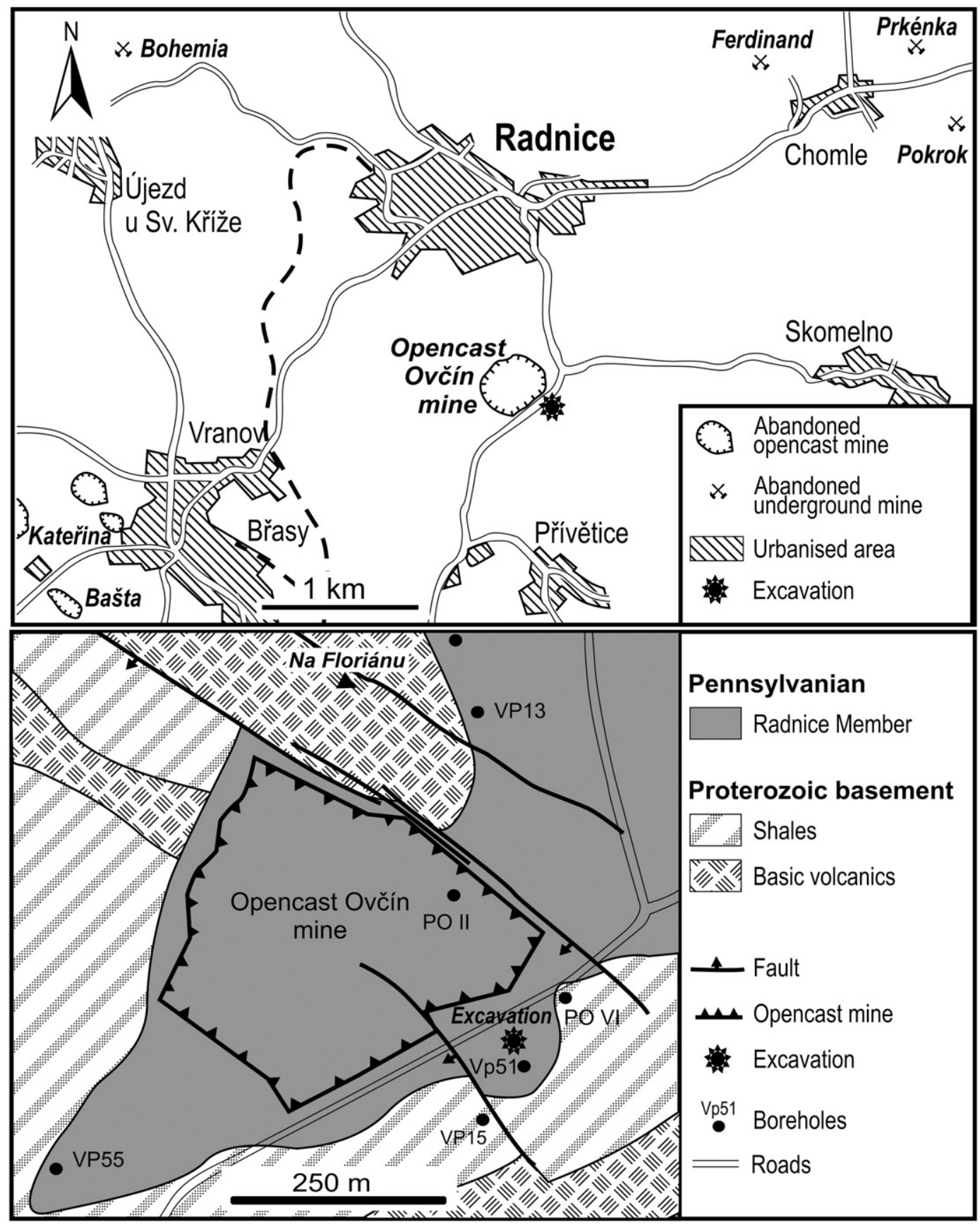

Fig. 4. Geographic location of the opencast Ovčín Mine. Detail of the geographic location of the Sternberg excavations. 


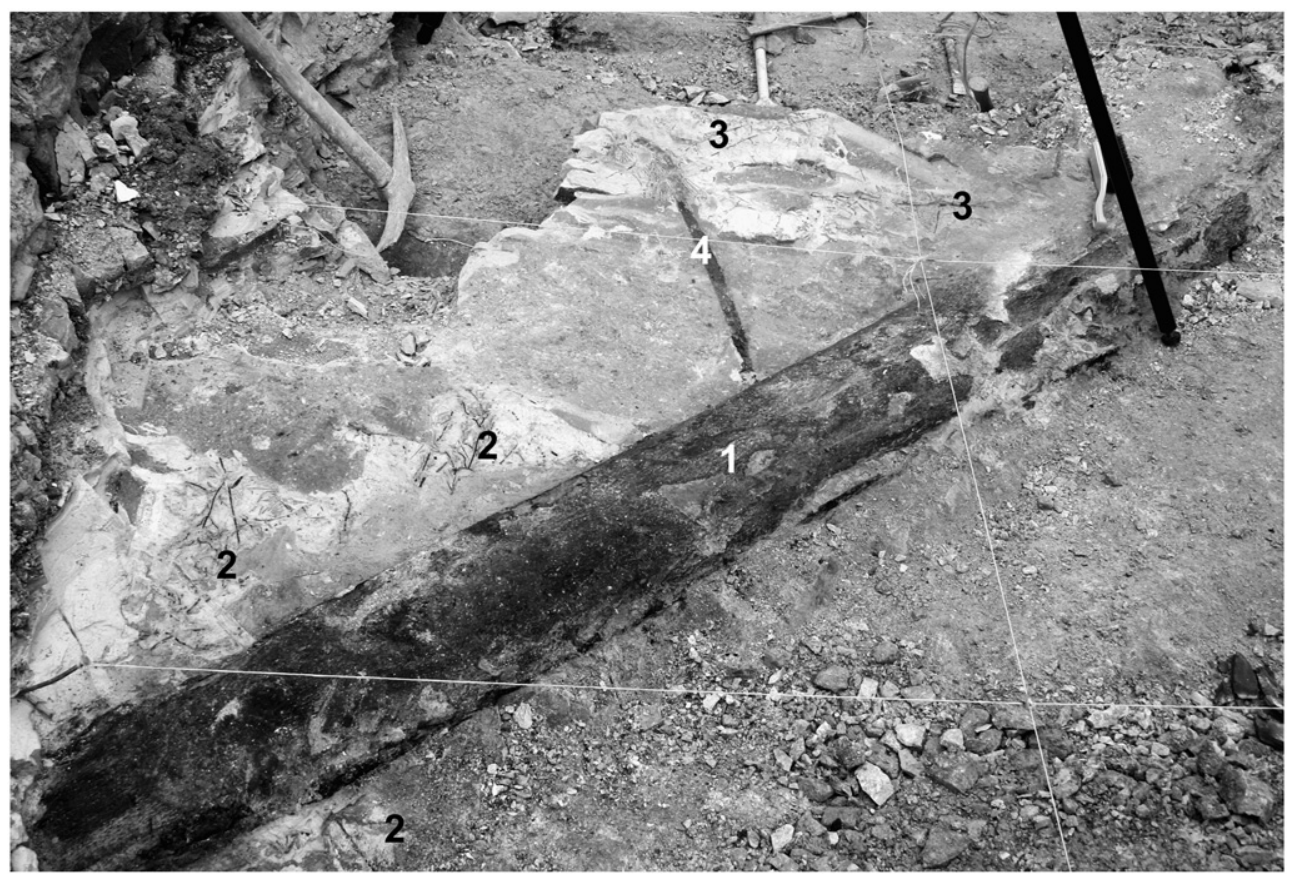

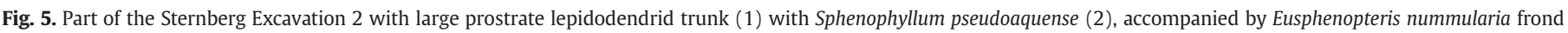
fragments (3) and Lepidophloios cf. acerosus (4) branch in upper part of the Bělka bed. Excavated area is divided with string into $1 \mathrm{~m}^{2}$ units.

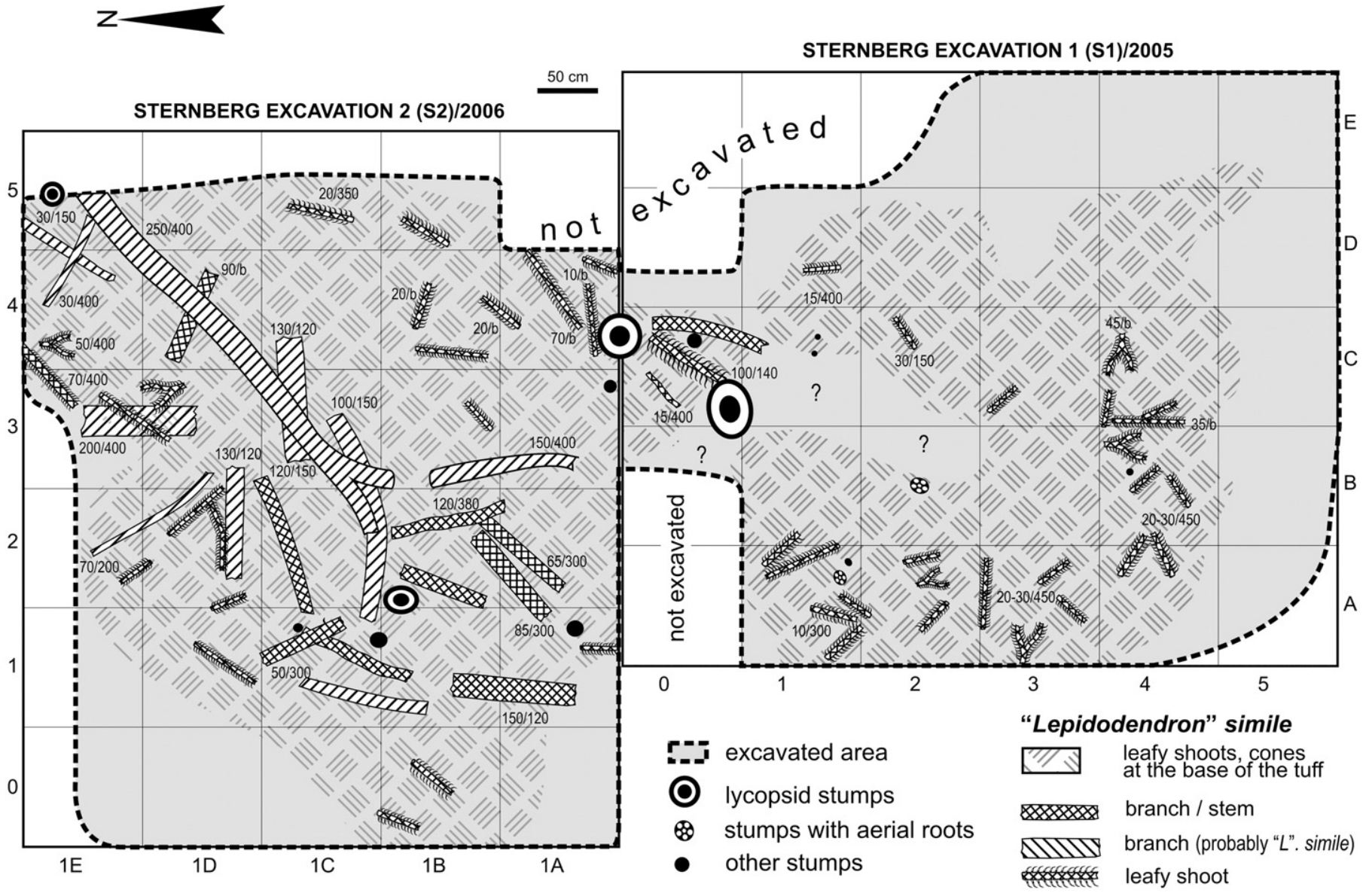

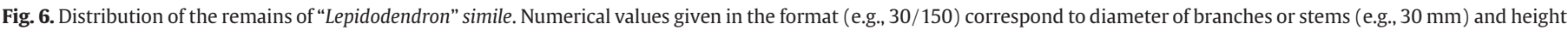

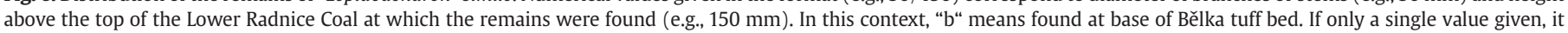
relates to the distance above the Lower Radnice Coal. 
possibly of Vulcanian or Plinian type (sensu Newhall and Self, 1982). The load of ash initiated compaction of the thick peat that became the Lower Radnice Coal, which forced large quantities of water to escape from the mire and flooded the overlying volcanic ash. Valley bottoms changed into shallow lakes, into which reworked, unconsolidated ash from the surrounding basement ridges was deposited (the Brousek unit). Rapid accumulation of this volcaniclastic and siliciclastic admixture further enhanced peat compaction, but eventually the lakes shallowed and ultimately formed the surface upon which the mire that became the Upper Radnice Coal was established.

\subsection{Fossil record, taphonomy and burial history of the Whetstone Horizon}

Opluštil et al. (2007) provided an overview of the fossils found in the Whetstone Horizon from various locations in the Czech Republic. Plant and invertebrate fossils are present in both the Bělka tuff bed at the base of the horizon and the overlying tuffite and tuffaceous mudstones of the Brousek unit (Fig. 3). However, the concentration, distribution and completeness of fossil remains differ markedly in both parts. A manuscript detailing the taphonomy and burial history of these peat-forming forests is in preparation, but a summary of this information is provided here.

The Bělka bed contains an assortment of plant fragments of various sizes, including large axial fragments and nearly complete aerial plant parts. Upright casts of trees of several botanical affinities, enveloped by coalified plant tissues, are very common. These are unequivocally and exclusively rooted at the top of the underlying Lower Radnice Coal, with no indication of rooting at any level in the Bělka itself. The diameter of individual vertical stems varies from only a few millimetres to about $1 \mathrm{~m}$, and their height similarly ranges from a few decimetres to several metres. The tallest stem described from this horizon in the study locality was more than $6 \mathrm{~m}$ tall (Drábková, 1986), however, the average height is between 2 and $4 \mathrm{~m}$. The stems are filled by the same lithology that surrounds them. The quality of their preservation is usually higher in the Bělka bed and generally poorer in the mudstone complex above it, where some stems contain hollows. Lycopsid stems are usually decorticated near their base. Leaves remain attached to some upright axes, particularly in the sub-arborescent lycopsids and sphenopsids.

The distribution of plant fossils in the Bělka bed is laterally and vertically irregular. Locally the tuff bed is quite poor in fossils, especially in its upper and middle parts, but in other areas the fossils are densely packed throughout most of the bed thickness. Lateral changes in distribution reflect the structure and density of the former vegetation cover, whereas the vertical distribution is probably related to the plant growth habits. Their highest concentration is in the lowermost centimetres of the unit, where the well-preserved litter of canopy and understorey plants is represented by trunks, branches, foliage and fructifications, mixed together with some herbaceous ground cover species. The smaller stature plants were likely buried in place, whereas fragments of arborescent species likely were broken off the trees due to overloading by volcanic ash, with fragmentation occurring almost immediately after inundation. Plant remains are more or less randomly disposed, although within a small area they can be oriented in similar directions, probably as a consequence of the "domino effect" produced

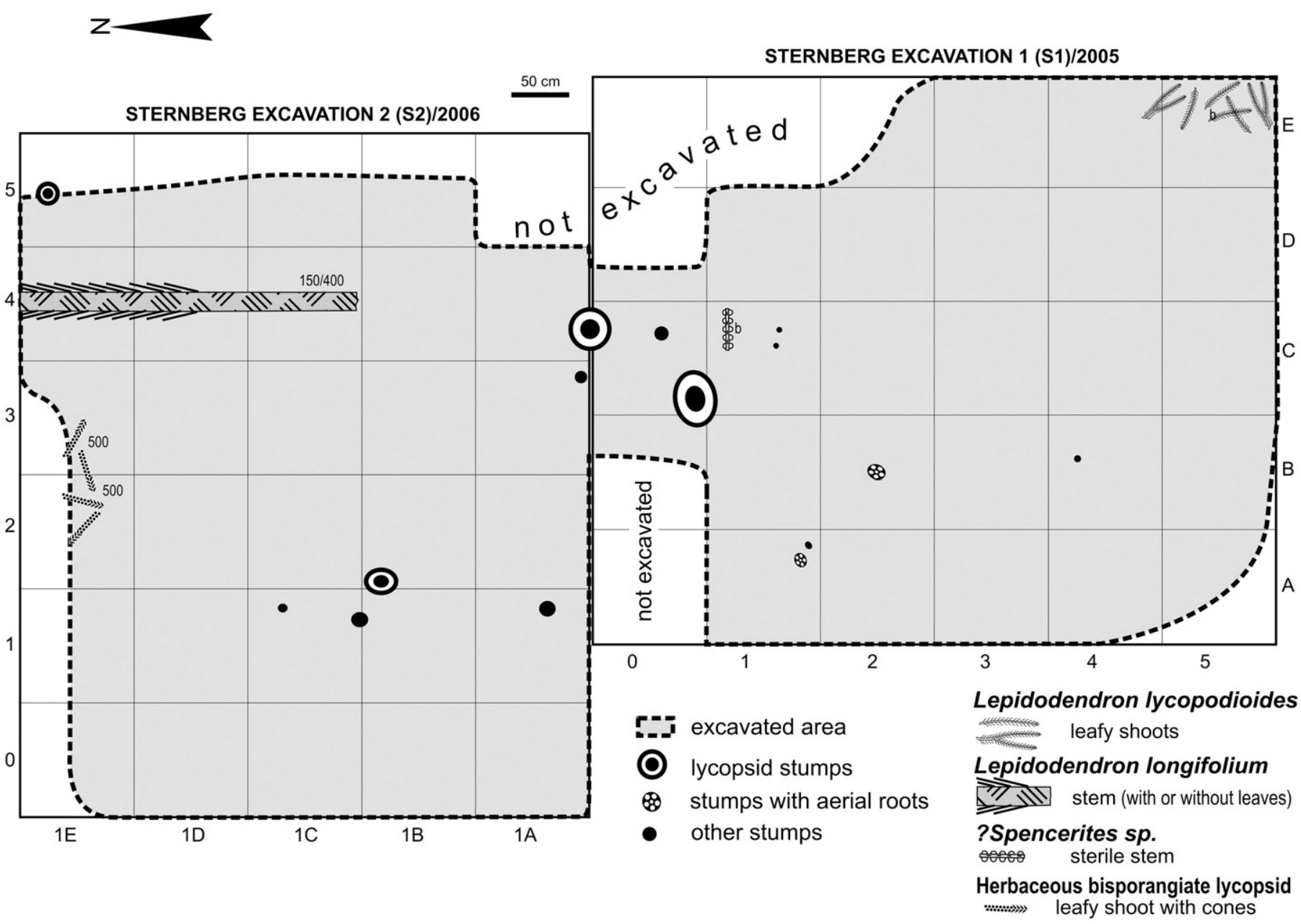

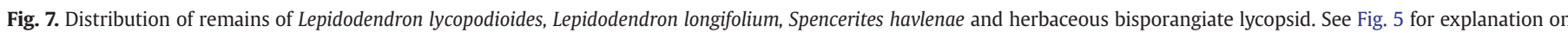
numerical values. 
by a falling tree. A notable characteristic of the assemblages is the clustering of branches, foliage and fructifications belonging to the same parent plant, some of which are in organic connection. Such close associations of various organs from the same species suggest that they were broken from a tree together under the weight of volcanic ash. The fact that leaves often remain connected to the branches indicates that these plants were very much alive when covered by the volcanic ash.

Plant remains at the contact with the underlying coal are usually comparatively poorly preserved. A logical interpretation is that this vegetation was already dead at the time of the eruption, with subaerial exposure and rapid microbial decay (Gastaldo, 1994; Gastaldo and Staub, 1999, and references therein) of this litter occurring on the floor of the peat-forming forest prior to being covered by ash. Irregularly distributed tree branches and the fronds of understorey plants are the dominant components of the middle and upper parts of the Bělka bed, whereas ground cover species are generally absent except in the vicinity of erect stems.

The fossil record of the overlying Brousek complex, which records lacustrine deposition, differs substantially from that of the Bělka bed. The unit is characterised by rare, fragmentary plant remains that preferentially occur in the lowermost 3 to $5 \mathrm{~m}$ of the horizon. The detritus is either indiscriminately scattered throughout the horizon, or concentrated along discrete bedding planes. Together with the conspicuous absence of roots, these features clearly indicate an allochthonous origin for the flora. The size of the fragments is more or less constant within any particular horizon, implying sorting due to water transport, and some of the largest phytoclasts are concentrated in the basal few centimetres of the unit. In the uppermost levels of the Whetstone Horizon, ichnofossils resulting from biological activities of insect larvae, amphibians and fish are common (Turek, 1989, 1996).
From a palaeoecological point of view, the flora preserved in the Bělka tuff bed represents an instantaneous snapshot (an autochthonous $T^{0}$ assemblage) of the peat-forming vegetation of the mire that ultimately became the Lower Radnice Coal. The flora of the overlying Brousek mudstone complex was contemporaneous with that of the Bělka, but in contrast these plant remains were transported prior to deposition. Plant associations from the Brousek were derived from vegetation that colonised the mire and adjacent areas of clastic deposition, as indicated by the similar species composition of the Bělka and Brousek floras. However, a few pteridosperm and rare progymnosperm species found only in the Brousek unit indicate that some plants might also have been transported from the adjacent slopes of basement palaeohighs along the palaeovalley margins. This scenario is plausible since the palaeovalleys were narrow and upland areas were locally within a few 100s of metres of the mires (Opluštil, 2005b).

\section{Locality details and study methods}

Data gathered and interpreted in this paper were obtained from two adjacent excavations located about $100 \mathrm{~m}$ east of the former opencast Ovčín Mine in the southern part of the Radnice Basin (Figs. 1B, 4). The Lower and Upper Radnice coals were exploited between 1979 and 1986 in the mine, where they are separated by a 9.5 to $12 \mathrm{~m}$ thick Whetstone Horizon. The Bělka tuff bed is seen at a depth of 1 to $8 \mathrm{~m}$ in the mine surroundings, but in areas close to the surface it is strongly weathered and fossils are poorly preserved. Therefore, sites where the Bělka is between 5 and $7 \mathrm{~m}$ deep were chosen for study. Our excavations were done in consecutive field seasons, with "Sternberg Excavation 1" (hereafter S1) completed in 2005 and "Sternberg Excavation 2" (hereafter S2) in 2006. A total surface area of $50 \mathrm{~m}^{2}$ of the Whetstone Horizon was exposed in these two excavations.

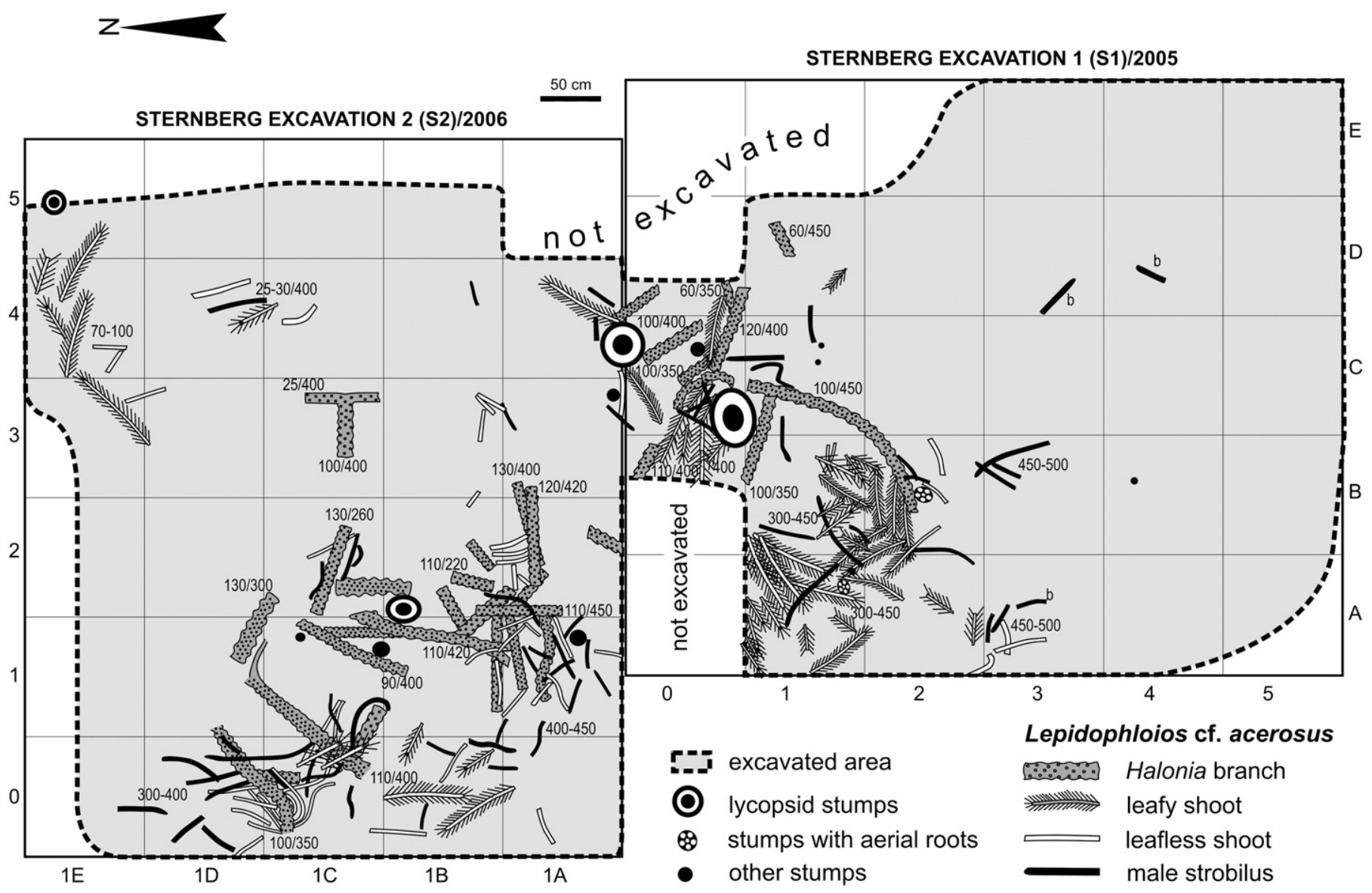

Fig. 8. Distribution of remains of Lepidophloios cf. acerosus. See Fig. 5 for explanation on numerical values. 
The first step was to have an excavator remove the Brousek down to a level just above the Bělka tuff bed. During this process we were on the lookout for casts of upright stems, although identification at this stage was difficult and in reality only a single lycopsid stem was found penetrating about $3 \mathrm{~m}$ above the Lower Radnice Coal (Plate III, Fig. 4). The exposed surface of the Bělka bed was divided with string into $1 \mathrm{~m}^{2}$ units that formed an $X Y$-coordinate system (Fig. 5). When it was necessary to achieve accurate coordinates for smaller plant remains, a $1 \mathrm{~m}^{2}$ wooden frame containing a $1 \mathrm{dm}^{2}$ grid was placed over the original $1 \mathrm{~m}^{2}$ unit. Since most of the vegetation was buried subhorizontally, each square unit was gradually quarried in about $10 \mathrm{~cm}$ thick slabs. This allowed for more complete recovery of the fossils, but also meant that $Z$-coordinates were obtained for each fragment by measuring its height above the contact with the underlying Lower Radnice Coal. As excavation progressed, the orientation and location of the fossils were accurately drawn onto a sheet of graph paper prepared for each square unit. The most noteworthy discoveries, such as large and well-preserved remains or plant fossil associations, were photographed as evidence for later interpretation. As a result of this process, the following information was recovered for each fossil, or group of fossils of the same taxon if found in a cluster: (i) taxonomic identity; (ii) size and shape of the organ, or diameter if an axis; and (iii) accurate $X Y Z$ coordinates and orientation in the excavation. In effect, the methods were analogous to those employed in an archaeological dig.

The identification of fossils during excavation was typically straightforward, particularly in the case of foliage, leafy shoots and fructifications, but was more difficult when attempting to determine the affinity of isolated axes of pteridosperms, cordaitaleans and decorticated branches or stems of lycopsids. The most problematic findings were therefore determined later in the West Bohemian
Museum in Plzeň (WBMP), where all of the palaeobotanical material from the excavations is now stored. Where plant remains were densely packed in the Bělka bed, it was often impossible to excavate some fragments without destroying others. Furthermore, many fossils could easily be overlooked, especially in the basal 1 to $3 \mathrm{~cm}$ of the unit where they were concentrated. Although time constraints did not allow for detailed documentation of each fossil within these densely packed horizons, we recognised the value of the data they held. In such situations, large blocks of fossiliferous tuff were given accurate coordinates prior to excavation and transportation to the WBMP. Once in the laboratory, fossils within the blocks were gradually uncovered before identification and reassignment to their appropriate coordinates. We estimate that 30 to $50 \%$ of the lowermost Bělka bed was documented in this way. Similarly, when large specimens were encountered in the excavation, they were cut from the tuff bed with a rock saw and removed to the WBMP as an entire block or series of blocks. Although this enabled us to preserve the largest specimens intact, a small part of the fossil record was unavoidably lost in the process because the ca. $10 \mathrm{~cm}$ thick tuff surrounding the extracted fossil could not be analysed for its fossil content. However, we estimate that less than $3 \mathrm{~m}^{2}$ of the Bělka bed was undocumented for this reason.

After further examination and revision of all specimens stored in the WBMP, the individual sheets of graph paper - each containing the localised graphical representation of fossil remains for a $1 \mathrm{~m}^{2}$ unit of excavation - were scanned and digitised. A template representing the excavation surface was created in CorelDRAW, and separate layers were constructed for each species (see Figs. 6-17). Thus, the exact $X Y$ coordinates for each taxon are faithfully represented in plan view over the entire excavation surface, and the height of each fragment (or cluster of fragments) above the base of the Bělka is given numerically

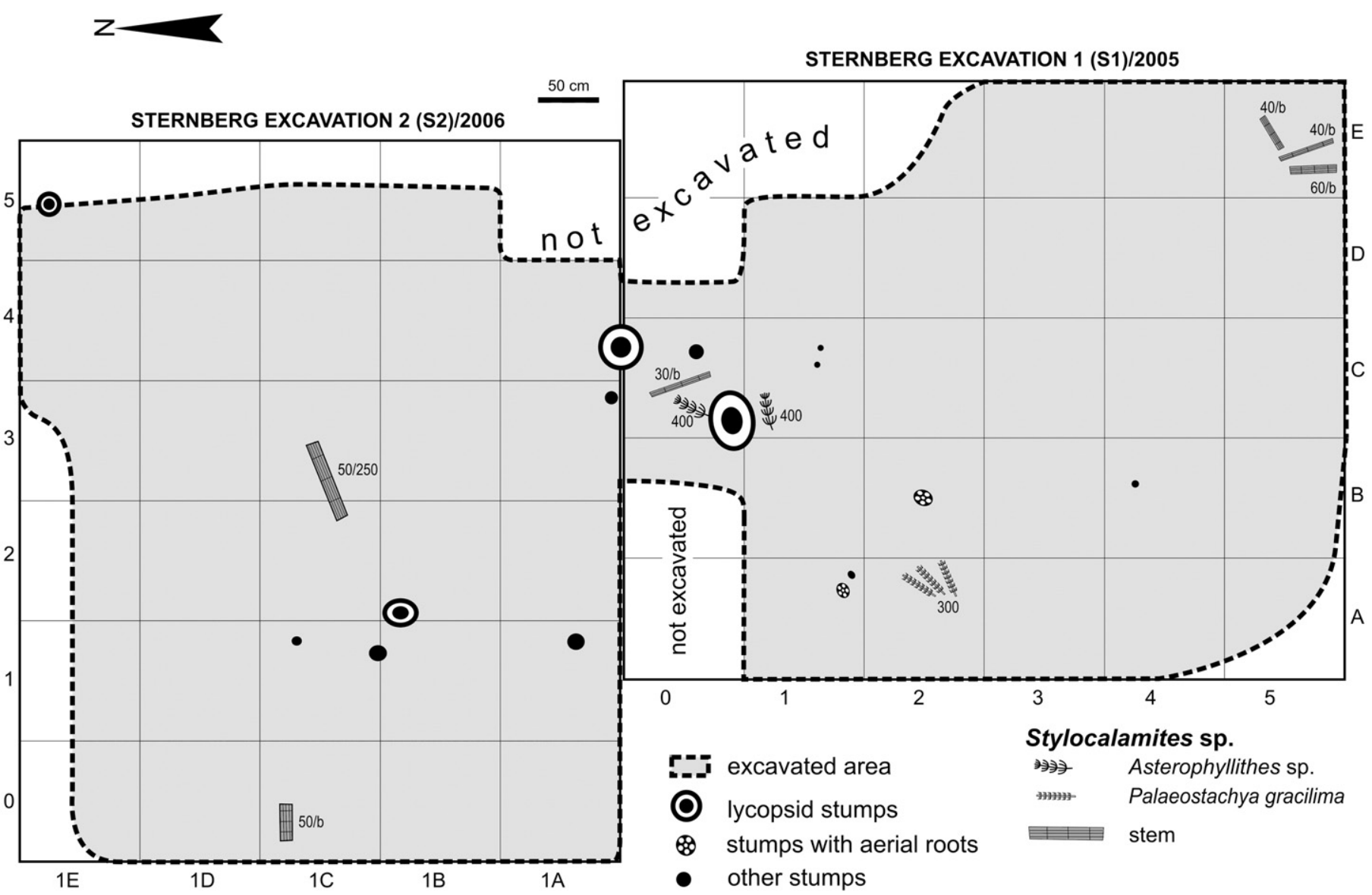

Fig. 9. Distribution of stems of Stylocalamites sp., foliage of Asterophyllites sp. and cones Palaeostachya gracilima. See Fig. 5 for explanation on numerical values. 


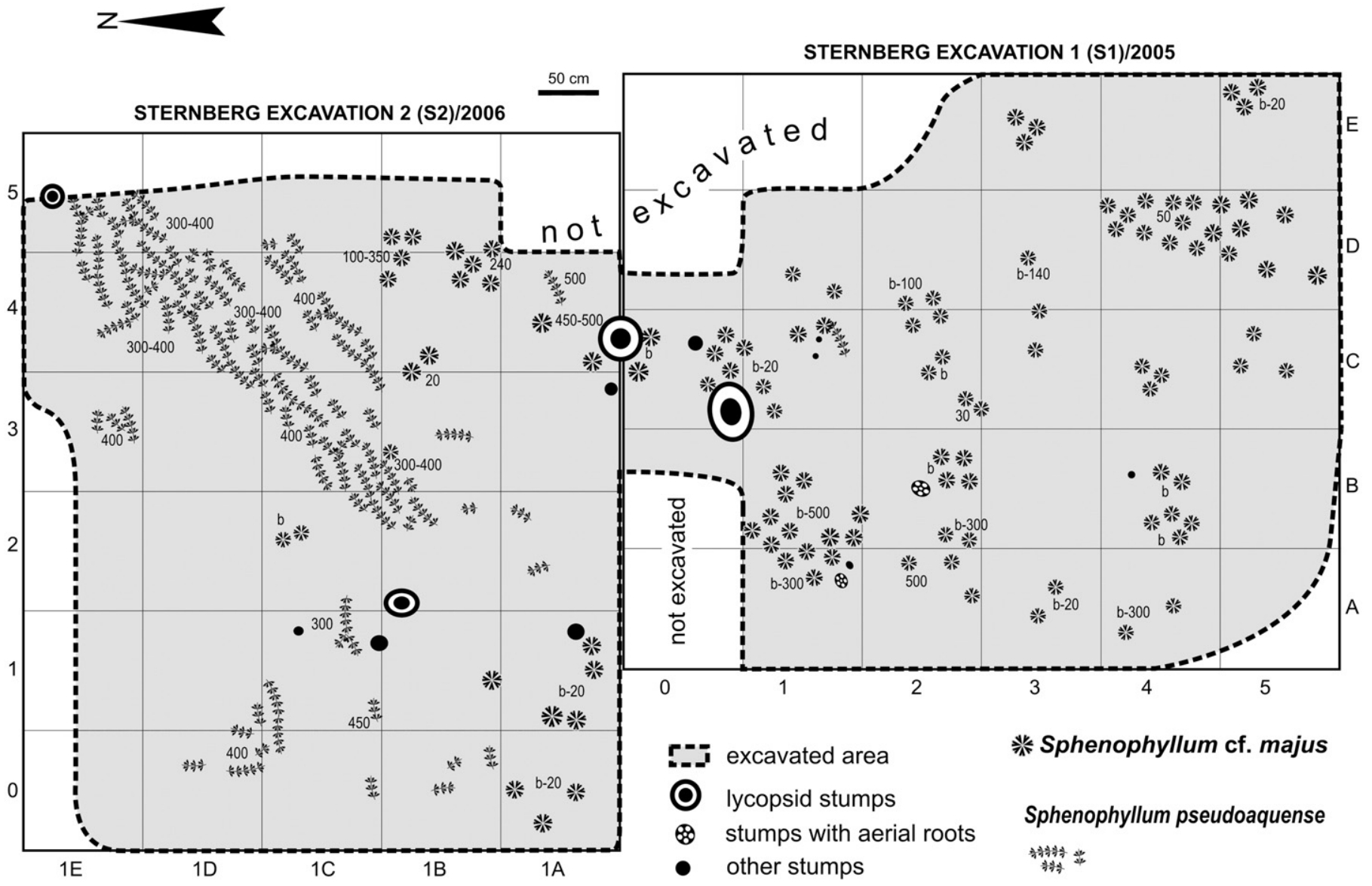

Fig. 10. Distribution of remains of Sphenophyllum cf. majus and Sphenophyllum pseudoaquense. See Fig. 5 for explanation on numerical values.

in millimetres. Construction of these layers enabled us to depict each species separately, or to show the combined spatial distribution of selected taxa (e.g., those of the same growth habit), simply by selecting or deselecting layers to be viewed in the software program. In the process of digitising the distribution of fossil remains, two main methods were used: (i) the outline of the vegetation was traced in the exact position it was found (typically the case for stems, large branches or Cordaites leaves); or (ii) representative icons were used (typically the case for herbaceous plants, small ferns or leafy shoots of lycopsids). In order to depict the distribution of plant litter preserved at the base of the Bělka tuff bed, an appropriate pattern was used for the arborescent species "Lepidodendron" simile (Fig. 6) and Cordaites borassifolius (Fig. 17). These patterns indicate the presence of a mixture of leafy shoots, leaves and/or fructifications that belong to the same parent plant species.

The graphical distribution for each taxon (Figs. 6-17) gives the impression that most plant axes are broken into small fragments that typically are not longer than a few $10 \mathrm{~s}$ of centimetres. This is in fact incorrect, and represents a negative artefact of the collection process. In reality, most of these "fragments" were originally longer or more complete, but for various reasons it was not possible to excavate them in their entirety. This artificial fragmentation of plant axes, however, has not significantly affected our ability to make sound taphonomic or palaeoecological interpretations in the process of reconstructing the entombed forest. It was much more difficult to identify whether prostrate stems and branches belonged to vegetation that was already dead prior to the eruption, or whether they were living and uprooted or broken due to overloading by volcanic ash.

Palaeoecological interpretation of the data was supported by calculating the "percentage cover" of each taxon, or group of taxa with similar growth habits. Percentage cover is simply the total surface area covered by a species, or group of species, divided by the total surface area of the excavation, and is thought by some authors to be a proxy for the original biomass of the forest (e.g., Scott, 1977; Pryor and Gastaldo, 2000). Estimates of tree heights were calculated using the formulae introduced by Niklas (1994), who described the allometric relationship between the diameter (Diameter Breast Height - DBH) and extrapolated height of stems from several types of growth forms of extant plants. The vagaries of excavation often precluded measurement of stumps at $\mathrm{DBH}$, which has resulted in overestimation and underestimation of some tree heights - such occasions are noted in the text. Although lycopsid axes comprised little true wood, their thick rind of bark (periderm) was very wood-like (DiMichele and Phillips, 1994). For this reason, we have used the allometric equation for "woody" species given by Niklas (1994) for estimating lycopsid heights.

\section{Results}

\subsection{Composition of the plant taphocoenoses and distribution of species}

Within the $50 \mathrm{~m}^{2}$ area of excavation, a total of 27 morphotaxa were distinguished, which we estimate to represent 20 biological species (Table 1). Even within this small area, there were minor differences in diversity and proportions of individual species between the excavation sites (S1 and S2). For example, S1 contained 24 morphotaxa assignable to 18 biological species, whereas in S2 only 17 morphotaxa representing 13 biological species occurred (Table 1). In all, 6 lycopsids, 3 sphenopsids, 5 filicopsids, 5 pteridosperms, and 1 cordaitalean species were recovered. The arborescent plants "Lepidodendron" simile, Lepidophloios cf. acerosus and Cordaites borassifolius dominated in both excavations, and understorey and ground cover species were locally 


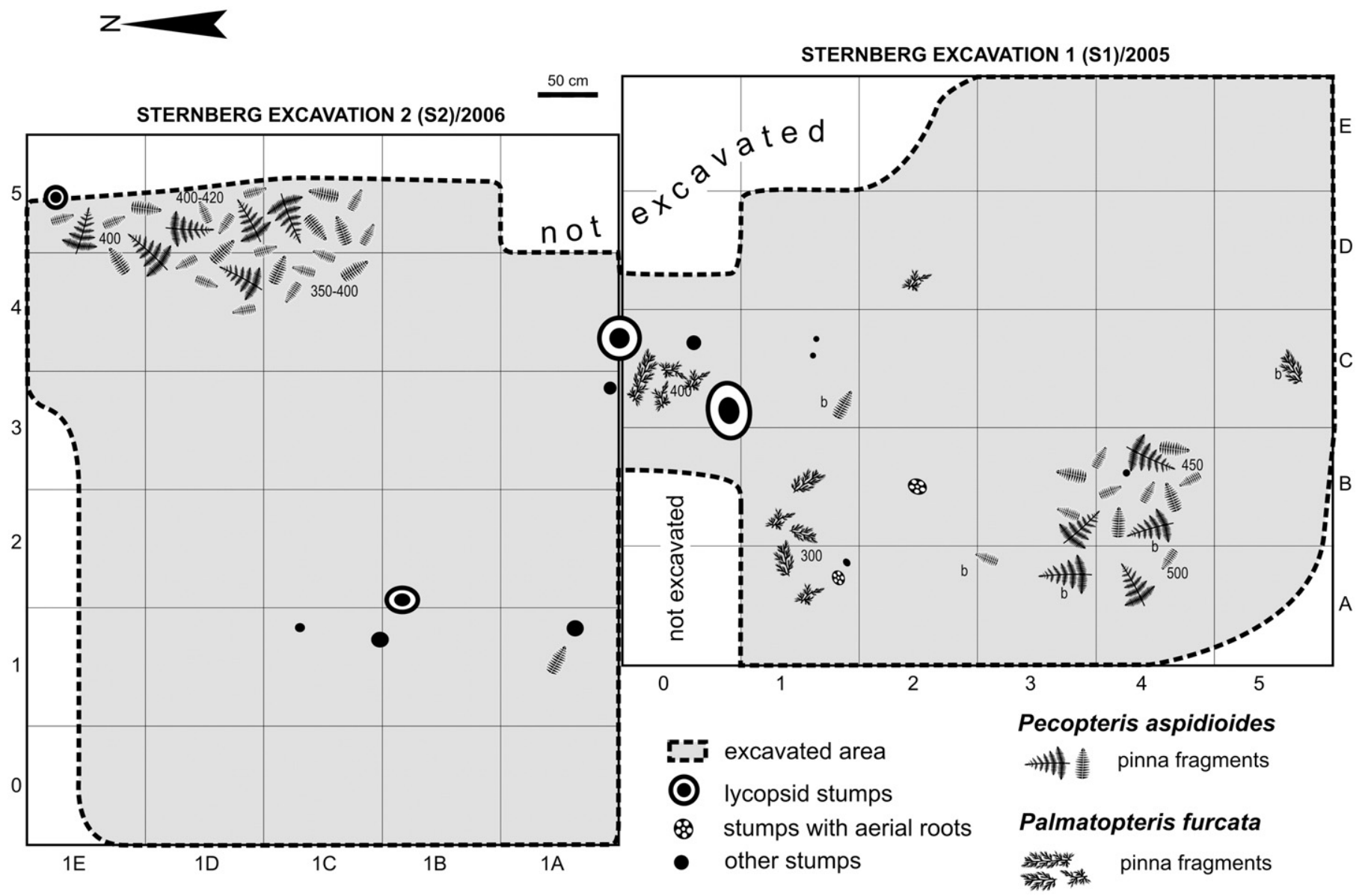

Fig. 11. Distribution of remains of Pecopteris aspidioides and Palmatopteris furcata. See Fig. 5 for explanation on numerical values.

important elements. In the following text, the distribution, abundance, and characteristics of each species are described separately in order to provide support for our palaeoecological interpretations. These are described as biological species, meaning that some involve several morphotaxa.

"Lepidodendron" (= Paralycopodites) simile sensu Němejc (1947), non Kidston (1909).

Under this name we include branches and prostrate or upright axes of various sizes, and leafy shoots that were often in organic connection with Flemingites-type fructifications (Plate I). Although no cones from these excavations were macerated for spores, Bek (1998) has shown them to be bisporangiate based on several specimens from identical stratigraphic levels in central and western Bohemia. The remains of this species covered $35.0 \mathrm{~m}^{2}$ (or $70.0 \%$ ) of the excavation area (Fig. 6; Table 2), and were often associated with ground cover and some understorey species. The highest concentration of "Lepidodendron" simile occurred in the basal 1 to $5 \mathrm{~cm}$ of the Bělka bed, where leafy shoots, $10 \mathrm{~s}$ of fructifications, and locally branches $10 \mathrm{~s}$ of millimetres wide were densely packed together without any preferred orientation (patterned area in Fig. 6). Higher in the Bělka bed, "L." simile became less common and more scattered in distribution. In the upper part of the tuff bed, large branch fragments reaching $150 \mathrm{~mm}$ in diameter were common, especially in S2 and adjacent parts of S1. A branching axis over $3 \mathrm{~m}$ long and about $250 \mathrm{~mm}$ wide, with leaf cushions resembling "L." simile (Plate I, Figs. 1-3), was found in S2, with the main dichotomy pointing towards the southwest at an azimuth of $270^{\circ}$ (Fig. 6). The dichotomising part was situated about $250 \mathrm{~mm}$ above the top of the coal seam, and the two branches produced by forking were about $150 \mathrm{~mm}$ in diameter. Another branch of similar width ran from the stem to the coal below. In the opposite direction, the axis gradually approached the base of the tuff bed, and continued beyond the northeastern margin of S2 where it presumably was rooted in the coal seam. Remains of "L." simile occurred in association with Lepidophloios cf. acerosus and Cordaites borassifolius, and the area of overlap in the distribution of these arborescent species was between 2 and $3 \mathrm{~m}$ wide.

Interpretation: Given that the area of distribution of "Lepidodendron" simile remains was about $10 \mathrm{~m}$ long and 4 to $5 \mathrm{~m}$ wide, it is assumed that several fully matured trees bearing fertile organs grew either directly in, or proximal to, the excavated area. Within the excavations there were only two possible candidates among preserved upright stems. One of these was at the northeastern edge of S2 in unit 1E5 (200 mm diameter), and the other in the central part of S2 in unit 1B2 (250 mm diameter) (Fig. 6). These decorticated upright stems are interpreted as belonging to lycopsids based on their swollen bases and a surface ornamentation typical of lepidodendrid casts. No upright stems that could be assigned to this species were found in S1. However, the absence of remains along the southern margin and an increasing concentration in the western part of the excavation indicates the presence of one or two trees just to the west of S1. Furthermore, the concentration of "L." simile remains, particularly leafy shoots, along the southeastern margin of S2 and northern margin of S1 suggests that one or two other trees were located just to the east of the excavated area. The prostrate, branched stem in S2 likely was rooted several metres beyond the northeastern corner of this excavation. It was almost certainly alive at the time of eruption, as indicated by its well-preserved leaf cushions and the presence of Sphenophyllum pseudoaquense wrapped entirely around the axis (Fig. 5), and probably fell down under the load of volcanic ash. 


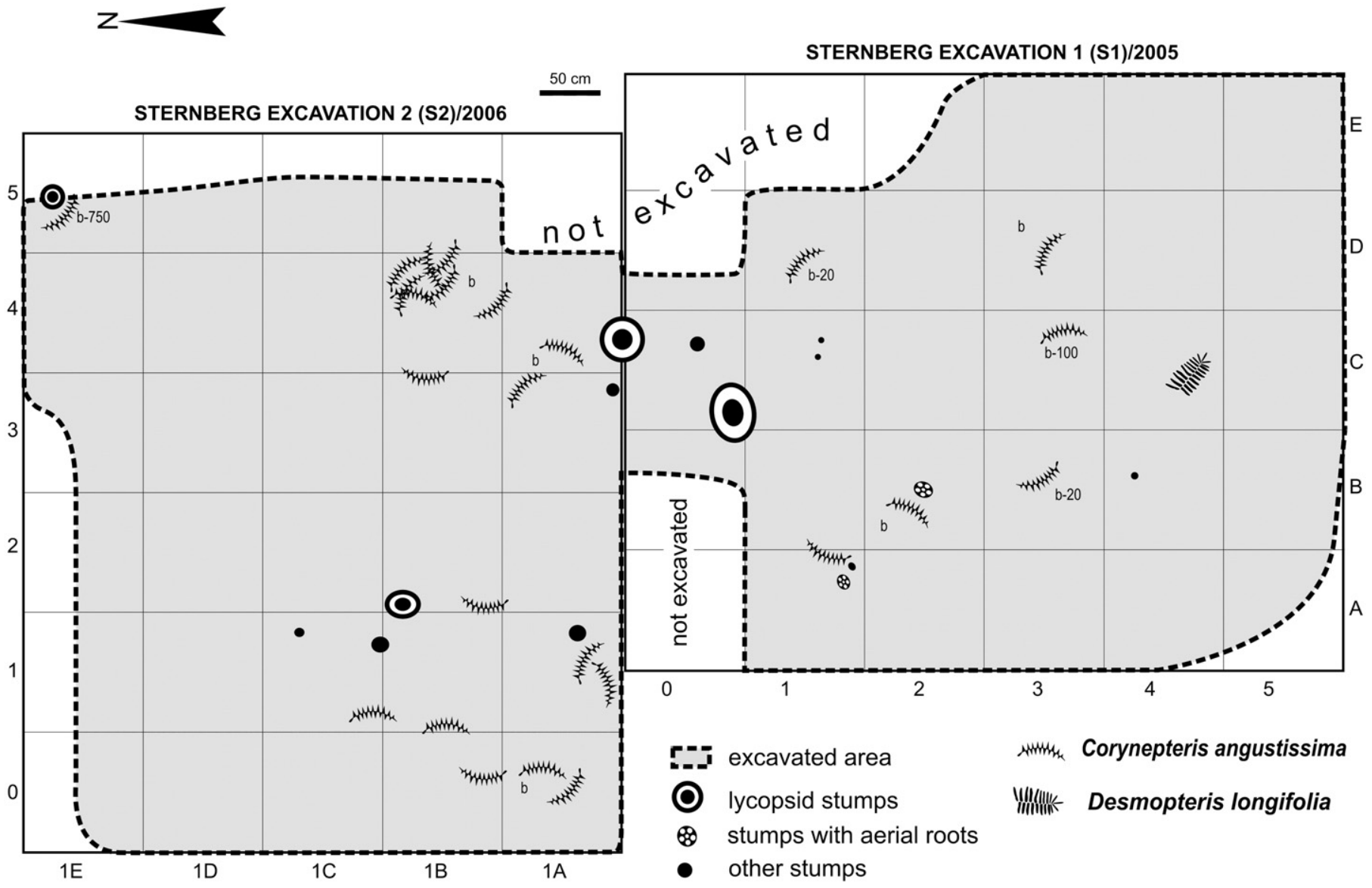

Fig. 12. Distribution of remains of Corynepteris angustissima and Desmopteris longifolia. See Fig. 5 for explanation on numerical values.

The presence of bisporangiate Flemingites-type cones indicates that this species belongs to the genus Paralycopodites, rather than true Lepidodendron. The latter genus name is accordingly placed in quotation marks in this paper, and formal taxonomic reassignment of this plant will be detailed in an upcoming paper. Members of the genus Paralycopodites were polycarpic, with opposite rows of short, deciduous lateral branches arising from a pole-like trunk (DiMichele, 1980; Phillips and DiMichele, 1992). Cones were borne on these lateral branches and produced in abundance, and the top of the trunk only dichotomised in the late stages of determinate growth (DiMichele and Phillips, 1985). Based on the diameters measured for stumps presumed to belong to "Lepidodendron" simile (200 and $250 \mathrm{~mm}$ ), the trees ranged in height from 17.0 to $19.5 \mathrm{~m}$. These are rough approximations, and given that the diameters were taken from slightly flared bases rather than from DBH, they should be considered maximum heights. The abundance of leafy shoots, narrow branches, and Flemingites-type cones, together with the presence of the large, dichotomising axis in S2, indicates that the mire was buried at a time when several "L." simile trees had reached the final stage of their life cycles. Paralycopodites species growing in peat-forming habitats preferred mires that had exposed peat surfaces and developed adjacent to rivers, resulting in intermittent flooding and clastic input (DiMichele and Phillips, 1988, 1994, 1996). This assertion fits well with observations that the Lower Radnice Coal has a high ash content and thin but abundant clastic partings, leading to the interpretation that it was a rheotrophic mire that developed adjacent to an active fluvial system (Opluštil, 2005b).

Lepidodendron lycopodioides Sternberg (1821).

Only leafy shoots and narrow leafy branches (Plate II, Figs. 4, 5) were discovered at the southeastern corner of $\mathrm{S} 1$, where these remains covered an area of about $0.6 \mathrm{~m}^{2}$ (1.2\% of the excavated area) (Table 2; Fig. 7).
Interpretation: The absence of wide branches and limited percentage cover of remains of this species strongly suggests that the parent plant was rooted outside of the excavated area, probably a few metres beyond the southeastern corner of S1. No stumps attributed to this species were preserved, and we are thus unable to estimate the height of the tree. It is believed to be an arborescent lycopsid, although it is not known to what genus the plant belonged. The absence of infrafoliar parichnos scars indicates that it is not a true Lepidodendron, but more palynological work is required on the reproductive organs (preserved elsewhere) to determine if it has affinities with Paralycopodites, Diaphorodendron, Synchysidendron, or even Bothrodendron (see Němejc, 1947). Regardless, the fact that leafy shoots and branches are present suggests that this tree was also alive and may have been in its terminal, reproductive phase at the time of the eruption.

Lepidodendron longifolium Brongniart (1828).

In the eastern part of S2, a straight, unbranched, column-like axis approximately $3 \mathrm{~m}$ long and $150 \mathrm{~mm}$ wide was found about $400 \mathrm{~mm}$ above the top of the coal seam (Fig. 7). The bottom $1.5 \mathrm{~m}$ was leafless and displayed leaf cushions typical of Lepidodendron longifolium, whereas the upper part bore grass-like leaves over $200 \mathrm{~mm}$ long (Fig. 7; Plate II, Figs. 1-3). No branches, leafy shoots or fructifications belonging to this species were found.

Interpretation: The presence of a single, straight, unbranched stem, combined with an absence of fructifications, branches or leafy shoots, suggests that this specimen represents a juvenile plant with a polelike habit. This interpretation is supported by the fact that leaves are still attached in upper parts of the stem and that the outer bark surface has well-preserved leaf cushions - both of these features typically are absent in mature specimens. Furthermore, the presence of leaves in organic connection and the position of the axis in the upper part of the 


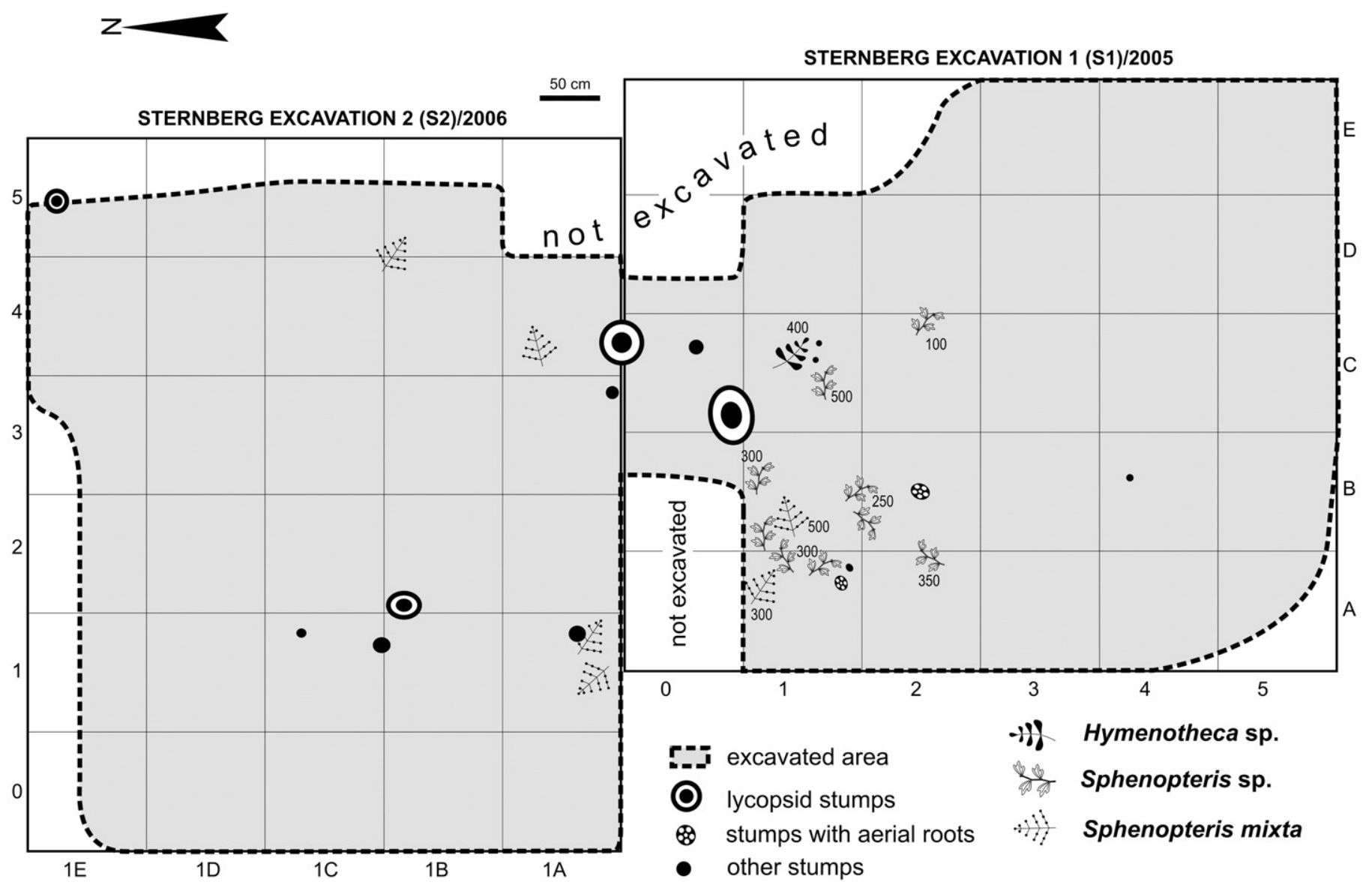

Fig. 13. Distribution of remains of Hymenotheca sp., Sphenopteris sp. and Sphenopteris mixta. See Fig. 5 for explanation on numerical values.

tuff bed indicate that the tree was alive at the time of eruption. It may have fallen over due to the weight of ash, or more likely was uprooted or broken by a branch falling from a higher tree in the vicinity. The base of the Lepidodendron longifolium plant may have been rooted; somewhere near the border of the two excavations.

This juvenile plant reached a minimum height of $14.0 \mathrm{~m}$ above the forest floor, based on a maximum preserved stem diameter of $150 \mathrm{~mm}$ (i.e., the point at which DBH could be measured is not preserved in the excavated area, but DBH would be wider than $150 \mathrm{~mm}$ ). According to Němejc (1947), this species does not have infrafoliar parichnos scars, and thus it probably belongs to either the genus Diaphorodendron sensu DiMichele (1985) or the genus Synchysidendron sensu DiMichele and Bateman (1992), rather than to true Lepidodendron. This is also supported by findings (in another part of the Radnice Basin) of branches of this species in organic connection with Lepidostrobus cermuus, a lepidocarpalean cone that produced Cappasporites microspores (Bek, 1998). At this time, the generic affinity of Lepidodendron longifolium remains uncertain. Members of Synchysidendron were monocarpic with tall, straight columns throughout most of their life, and a branching, cone-bearing "crown" was only produced in the terminal, reproductive phase of growth (DiMichele, 1979a; Wnuk, 1985; DiMichele and Bateman, 1992; Phillips and DiMichele, 1992). When occurring in mires, these plants apparently had a diffuse distribution, preferred stable, exposed to partially submerged peat substrates, and were associated with diverse plant assemblages (DiMichele and Phillips, 1985, 1994). In contrast, the genus Diaphorodendron was characterised by an unbranched columnar trunk, from which deciduous or retained lateral branches arose. Cones were borne from the tips of these branches, and the trees were long-lived with continuous or repeated (polycarpic) reproduction (Wnuk, 1985; DiMichele and Phillips, 1985; Phillips and
DiMichele, 1992). Members of the genus could apparently tolerate varying edaphic conditions, but those centred in mires were associated with a diversity of vegetation and preferred saturated but only occasionally flooded peat (DiMichele and Phillips, 1994).

Lepidophloios cf. acerosus Lindley et Hutton (1831).

A $3 \mathrm{~m}$ tall upright stump (320 $\mathrm{mm}$ diameter) with Lepidophloios leaf cushions (Plate III, Fig. 1) was found in the centre of the excavation area (units C0 and 1A4), around which leafy and leafless shoots and narrow male cones reaching $800 \mathrm{~mm}$ long were scattered (Fig. 8). The cones were either isolated or in organic connection to Halonia-type branches (Plate III, Figs. 2-4), some of which reached $2 \mathrm{~m}$ long. Other shoots and Halonia-type branches occurred along the western margin of S2, as well as in its northeastern corner. A wider (550 mm diameter) but shorter stump with a flared base was also found in unit C0 of S1, and it may also belong to this species (Plate IV, Figs. 1, 2). The remains of this plant covered $18.5 \mathrm{~m}^{2}$ (37.0\%) of the excavated area (Table 2).

The Halonia-type branches are between 60 and $130 \mathrm{~mm}$ wide, and some of them reached a length of $2 \mathrm{~m}$ despite being incomplete. Branching was either T-shaped (unit 1C3 in S2) or at a wide, open angle of about $150^{\circ}$ (Plate IV, Figs. 3, 4). The best specimens with shoots and cones attached to Halonia-type branches were collected as single blocks for further study (Plate III, Fig. 3). Shoots and male cones are both approximately of the same diameter and length (ca. $800 \mathrm{~mm}$ ). Cones, which yielded miospores similar to Lycospora rotunda (J. Bek - pers. comm.), were attached directly to branches without any peduncle or stalk and alternate with leafy shoots. Although there was no clear pattern of alternation, the number of cones and shoots preserved in the tuff bed was roughly comparable. Shoots were either leafy or leafless, and although often found together, there were areas where one predominated. It may be that 


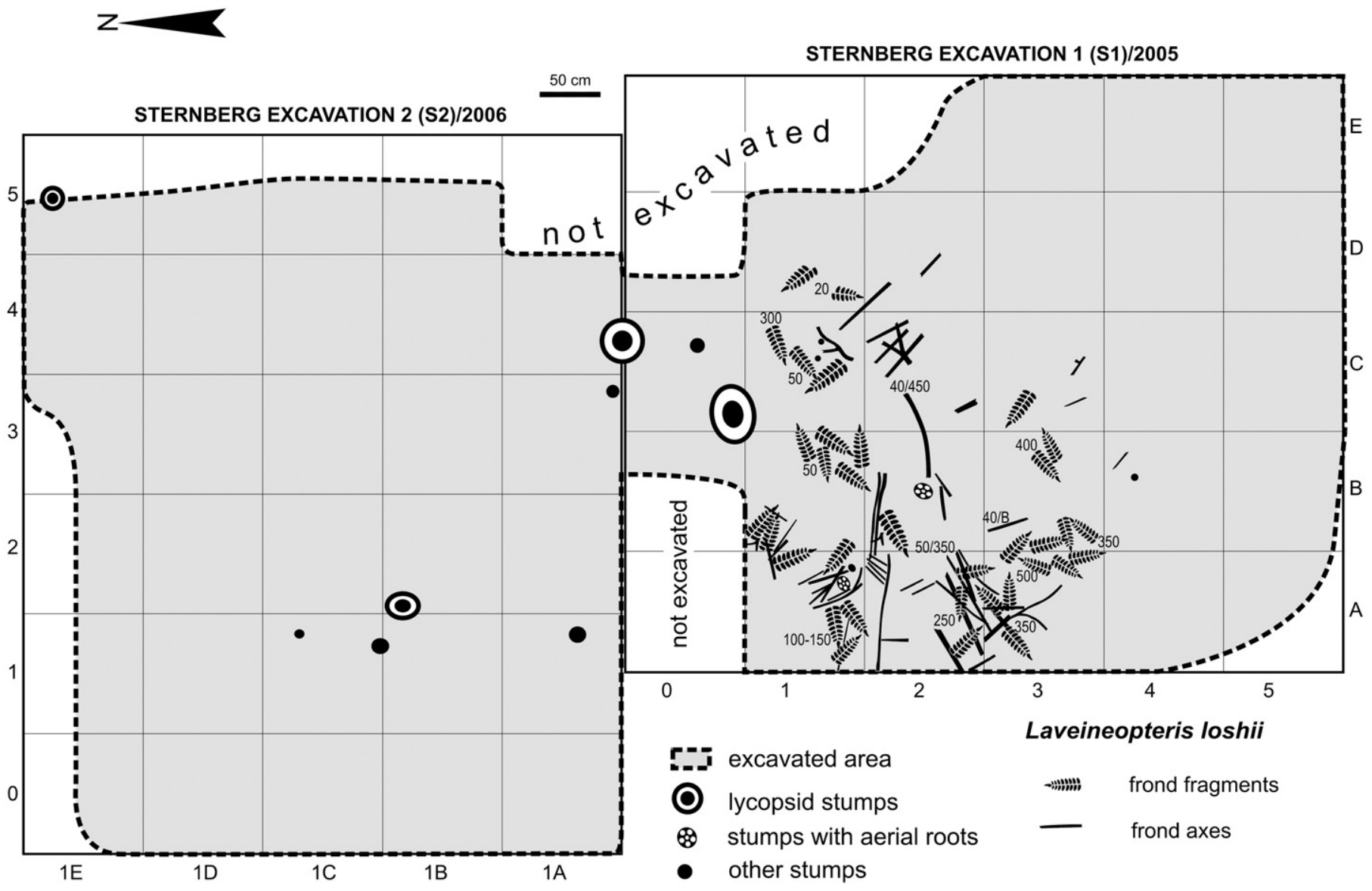

Fig. 14. Distribution of remains of Laveineopteris loshii. See Fig. 5 for explanation on numerical values.

leafless shoots were more mature, being located closer to the main axis.

Interpretation: The distribution pattern of Lepidophloios remains points to the existence of at least one, and probably two or even three, male trees that had reached sexual maturity within the study area and its proximity. The tall, erect axis in the central part of the excavation probably was the parent plant of all organs found in S1 and the adjacent part of S2, which indicates a "crown" diameter of 6 to $7 \mathrm{~m}$. The irregular distribution of the Halonia-type branches, shoots and cones around this stem can be explained by the fact that not all of the branches were broken from the tree at the same time. We suggest that the tree slowly disaggregated after the ash fall, and therefore some parts of the "crown" were absent from the Bělka bed. The accumulation of large Halonia-type branch fragments, leafless shoots and cones along the western margin of S2 suggests the presence of another fertile, male tree to the west of this excavation. Furthermore, several shoots and a single cone in the northeastern corner of S2 may be derived from one of the aforementioned trees, or may have fallen from another plant rooted to the north or northeast of S2. Finally, it is presumed that the widest lycopsid stump preserved in S1also belongs to this species, but the poor quality of preservation precludes confident assignment.

The genus Lepidophloios is characterised by tall, column-like poles that exhibited determinate terminal branching only in the final phase of growth, with the crown containing cones borne laterally from peduncles (DiMichele, 1979b; DiMichele and Phillips, 1985; Phillips and DiMichele, 1992). The trees were monocarpic, with massive cone production prior to death. The diameter $(\mathrm{DBH}=320 \mathrm{~mm})$ of the tall stump with Lepidophloios leaf scars in the excavation indicates that this tree reached $22.5 \mathrm{~m}$ high, making it the tallest species present. The large number of Halonia-type branch fragments, shoots and male cones indicates that most of these trees were alive and fertile when the swamp was covered in volcanic ash. However, the poor quality of preservation of the largest stump $(\mathrm{DBH}=550 \mathrm{~mm}$ wide) suggests that it may have already been dead at the time of the eruption - this tree would have reached $30.0 \mathrm{~m}$ in height. From a palaeoecological standpoint, Lepidophloios was centred in peat-forming swamps and could withstand long intervals of standing water (DiMichele and Phillips, 1994). Although this genus often dominates in low diversity coal ball assemblages in mires that were principally flooded, it is also known from more nutrient-rich peats that developed proximate to contemporaneous channels (DiMichele and Phillips, 1988), a situation comparable to that of the Lower Radnice Coal.

Spencerites havlenae Drábková, Bek et Opluštil (2004).

Only a single, ca. $150 \mathrm{~mm}$ long fragment (Plate II, Fig. 6) of this subarborescent lycopsid species was found in unit C1 (S1), and it represents a sterile part of an axis (Fig. 7). A similar specimen was uncovered from the same unit during laboratory examination. Both remains occurred near the base of the tuff bed, and consist of leafless axes with leaf scars. Spencerites havlenae covered an area of $0.4 \mathrm{~m}^{2}$, or $0.8 \%$ of the excavation surface (Table 2 ).

Interpretation: The fact that only two sterile axial fragments were found in the same unit points to the existence of a single plant. Drábková et al. (2004) reconstructed this plant as a primitive, dichotomously branching, sub-arborescent lycopsid that reached between 1.5 and $3.5 \mathrm{~m}$ in height, based on numerous exceptional specimens preserved in volcanic ash. It formed part of the understorey component of the forest, and evidence suggests that most lycopsids within this clade generally preferred more open mire conditions (Thomas, 1997). Spencerites seems to have grown exclusively in peatforming swamps, which explains its lack of preservation in associated roof-shales (Drábková et al., 2004). 


\section{Herbaceous bisporangiate lycopsid}

Fertile remains of this new taxon were found along the northern margin of S2 (Fig. 7; Plate II, Fig. 7), where they were associated with a sub-horizontally lying cordaitalean trunk that was entombed in both the upper Bělka and basal Brousek beds. Most of the remains were found in the Brousek bed, but a few specimens also occurred in the Bělka bed. This taxon covered $0.6 \mathrm{~m}^{2}$, or $1.2 \%$ of the excavation surface (Table 2).

Interpretation: Only one or few plants apparently grew in the northern part of the excavated area. The close association with a cordaitalean stem indicates that this species might have been a climber or epiphyte. The quality of preservation and presence of fertile remains suggest that it was alive and in a reproductive phase at the time of burial.

Stylocalamites Weiss (1884).

Calamiteans were represented by fragments of Stylocalamites stem compressions, pith casts (Plate V, Figs. 1, 2), leafy shoots bearing Asterophyllites foliage, and cones of Palaeostachya gracilima. Their remnants were, however, quite rare in both excavations (Fig. 9). Organs were found scattered in various but mostly marginal parts of S1, but leafy shoots and cones were very rare. In S2, only two widely separated stem fragments $50 \mathrm{~mm}$ in diameter were found in the central and western parts of the excavation. Stems were mostly found in the basal few centimeters of the tuff bed, whereas leafy shoots and cones generally occurred separately about 300 to $400 \mathrm{~mm}$ above the base. All of the organs covered $0.4 \mathrm{~m}^{2}$, or $0.8 \%$ of the excavation surface. Nodes were not always visible on the stem surfaces, and all of them lacked attached leafy shoots. For this reason, they have been included in Stylocalamites, a subgenus that Weiss (1884) introduced for calamiteans without branches, or that are only irregularly branching. We note that a few
Stylocalamites stems may have been overlooked during excavation, particularly if closely associated with other plant axes.

Interpretation: The scarcity and wide distribution of calamitean remains indicates that these plants grew in several small clusters, or possibly as individual plants, but their site of growth is uncertain. The rare occurrence of cones indicates that most of them were either sterile, juvenile plants, or that they were not fertile at the time of burial. The vertical separation of axes from leafy shoots and cones in the Bělka bed indicates that the components did not belong to the same individuals. Calamiteans typically were of short stature and common but diffuse components of Westphalian mires, and apparently preferred parts of peat bodies that were enriched in nutrients (DiMichele and Phillips, 1994), a situation similar to that interpreted for the Lower Radnice Coal. We assume that these calamiteans comprised part of the understorey of the forest.

Sphenophyllum cf. majus (Bronn) Bronn (1835).

Isolated verticils, single leaves, and naked or leaf-bearing axes, rarely with cones attached (Plate V, Figs. 3-6), were locally common throughout S1 and the adjacent southern part of S2 (Fig. 10). In the remaining parts of S2, it was found only exceptionally. This species covers $6.5 \mathrm{~m}^{2}$ (13\%) of the excavated area (Table 2), and displays a patchy distribution. Most of the remains occurred at or near the base of the Bělka bed, but locally they occurred throughout the entire thickness of the tuff or in its upper part, especially in the vicinity of erect stems.

Interpretation: The patchy distribution of this sphenophyll indicates the presence of several randomly placed plants growing close to one another. There is no evidence, such as spiny axes or climber hooks on leaves, that this species was capable of climbing arborescent vegetation, and likely formed a ground cover beneath other mire

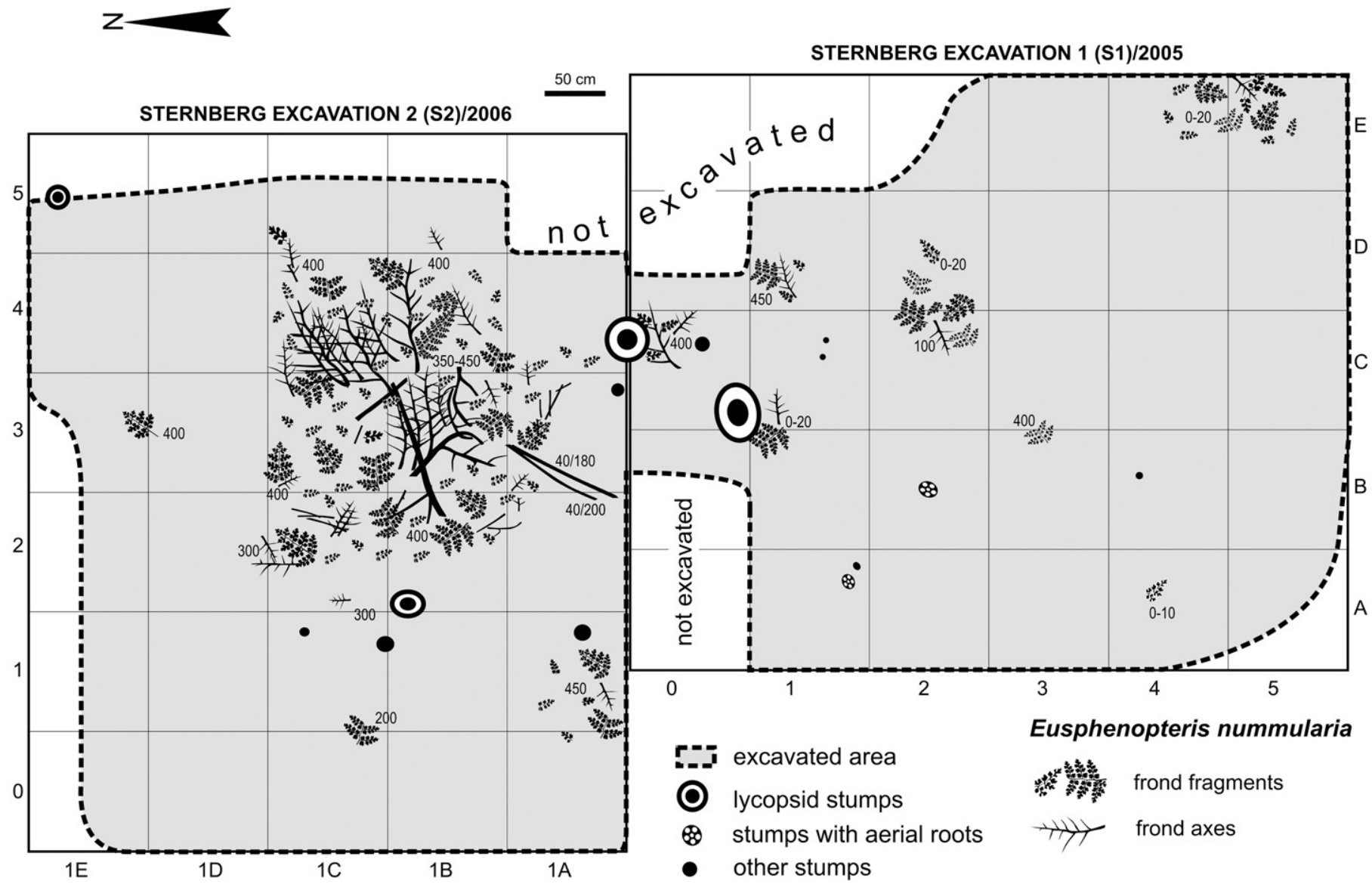

Fig. 15. Distribution of remains of Eusphenopteris nummularia. See Fig. 5 for explanation on numerical values. 


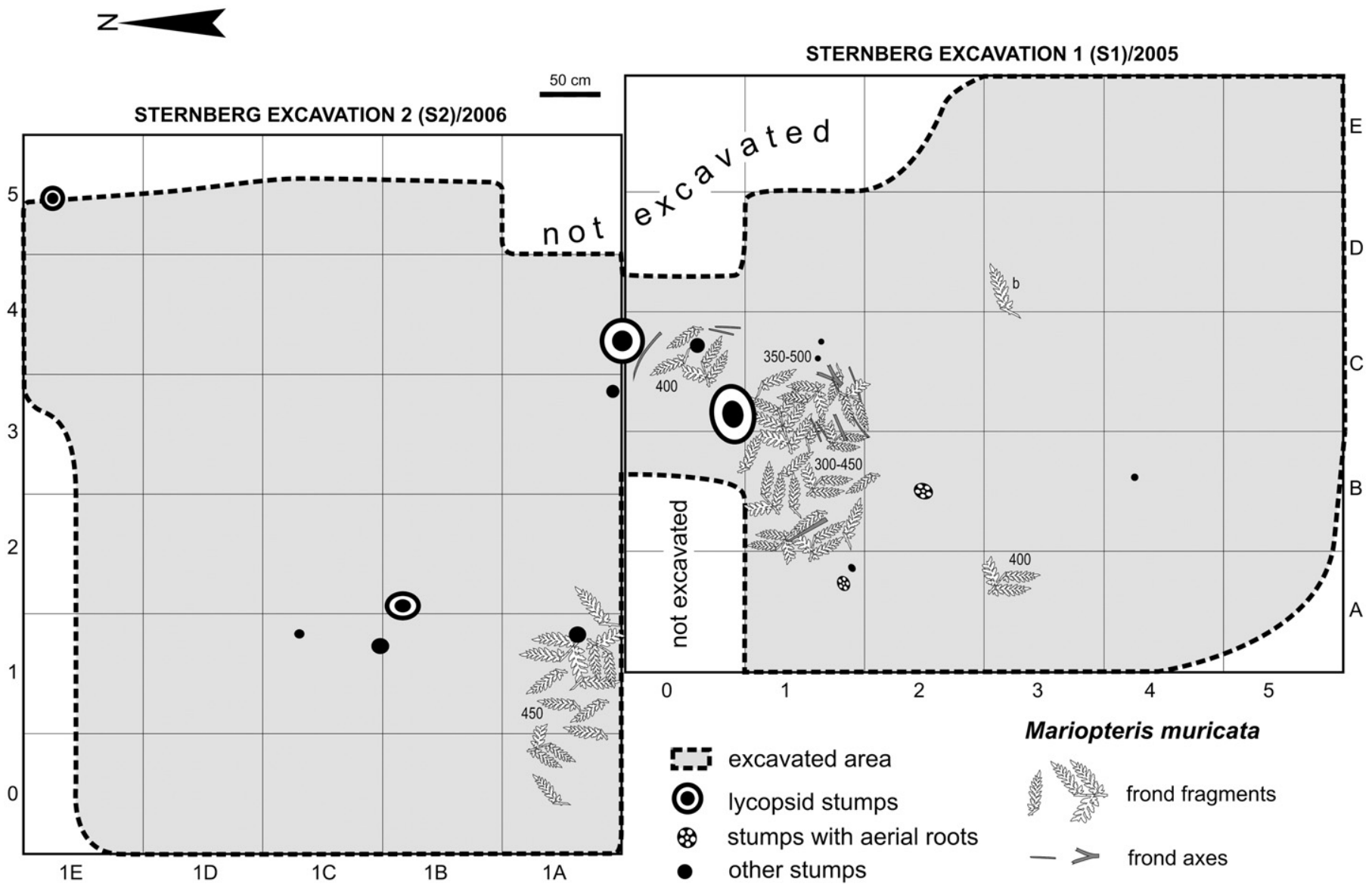

Fig. 16. Distribution of remains of Mariopteris muricata. See Fig. 5 for explanation on numerical values.

plants. According to Batenburg (1982), most sphenophylls from peatforming habitats had abundant adventitious roots and aerial branch systems, which were often leafless, arising from prostrate, rooting main axes. It is interesting to note that Sphenophyllum cf. majus is associated with nearly all other species found, but is markedly absent in the northern part of $\mathrm{S} 2$ where the remains of a cordaitalean tree that was living at the time of the eruption (see below) were concentrated. Although admittedly speculative, this observation suggests that $S$. cf. majus could not tolerate the heavily shaded areas beneath the leafy cordaitalean canopy, but instead preferred open, or at least diffusely shaded, areas where more sunlight reached the forest floor.

Sphenophyllum pseudoaquense Libertín, Bek and Drábková (2008).

Libertín et al. (2008) has formally described this new species, has foliage that strongly resembles Sphenophyllum aquense but very different cones. With the exception of a few scattered fragments in $\mathrm{S} 1$, the remains of this taxon were almost exclusively associated with the prostrate, dichotomising "Lepidodendron" simile trunk found in S2 (compare Figs. 6 and 10). Well-preserved, foliage-bearing axes of $S$. pseudoaquense were found encircling the entire length of the lycopsid, even its underside, and some sphenophyll axes sub-paralleled the lycopsid stem (Fig. 10; Plate VI). Both the lycopsid and the sphenophyll occurred about 350 to $400 \mathrm{~mm}$ above the base of the Bělka bed. Leafy axes of S. pseudoaquense were also common in the western part of S2, where they were similarly associated with branches of "L." simile. Several $10 \mathrm{~s}$ of cones were found, mostly attached to leafy axes. This species covered $6.5 \mathrm{~m}^{2}$, or $13 \%$ of the excavation area.

Interpretation: The distribution of Sphenophyllum pseudoaquense and its close association with the trunk and branches of "Lepidodendron" simile clearly indicates that this sphenophyll was a liana that climbed and covered arborescent vegetation. Such a relationship is most evident from the outline of distribution of S. pseudoaquense and the dichotomising lycopsid in the northeastern corner of S2. If this sphenophyll was a ground cover element, we logically assume that its distribution would be patchier and completely independent of the "L." simile remains. This species resembles modern bole climbers that adhere to trunks with specialized roots, although this has not been observed in the excavation. Instead, axes were covered by hook-like trichomes, and climber hooks also terminated the leaves on central and distal axes (Plate VI, Figs. 5-7). In modern tropical rain forests, bole climbers are especially common in humid climates that do not experience pronounced dry seasons (Whitmore, 2006).

The presence of a liana entwining the "Lepidodendron" simile trunk in S2 supports the interpretation that both plants were alive at the time of ash deposition. Furthermore, the fact that Sphenophyllum pseudoaquense covered the branching "crown" of this fertile tree indicates that the terminal growth phase of "L." simile, during which it dichtomised at its top, lasted at least long enough to be enveloped by the sphenophyll.

Pecopteris aspidioides Sternberg (1825).

This foliage belongs to a marattialean tree fern with a Psaronius trunk, and comprises sterile frond fragments and axes of various orders (Plate VII, Fig. 1). Most pinnate remains were less than 100 to $200 \mathrm{~mm}$ in size. Nearly all of the specimens were found in two separate concentrations; the first in the southwestern part of S1, and the second in a $1 \mathrm{~m}$ wide belt along the eastern margin of S2 (Fig. 11). Remains of this species covered $4.8 \mathrm{~m}^{2}$ (9.6\%) of the excavated area, and most pinnate fragments occurred between 400 and $500 \mathrm{~mm}$ above the top of the coal in the upper part of the Berlka bed. No stems with the adventitious, aerial roots typical of Psaronius were found in association with frond remains. 


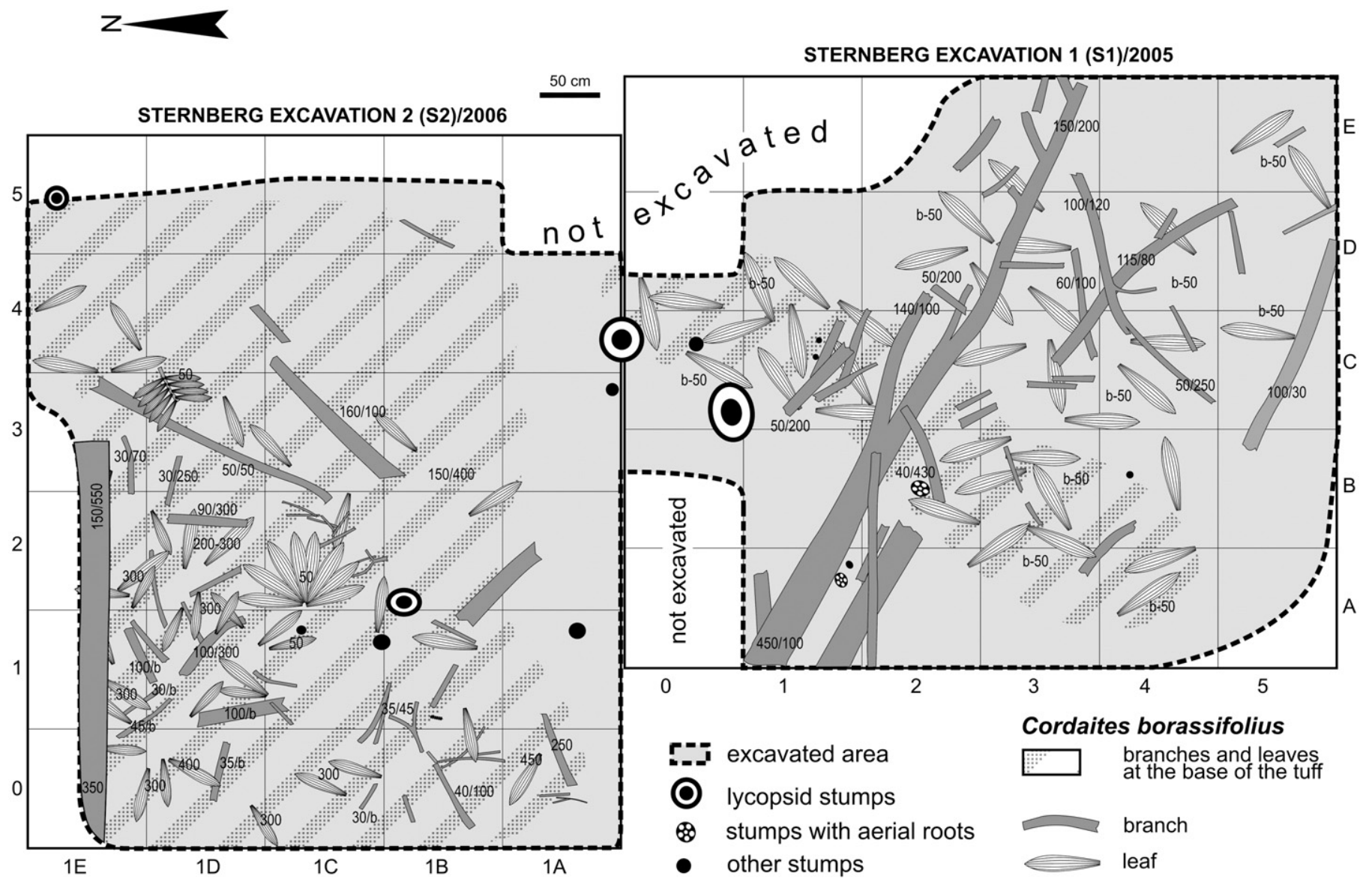

Fig. 17. Distribution of remains of Cordaites borassifolius. See Fig. 5 for explanation on numerical values.

Interpretation: The clustered distribution of this fern clearly indicates the presence of two plants rooted just beyond the excavated area. In S1, a tree fern was probably rooted just outside the southwestern margin, whereas another plant grew not more than $2 \mathrm{~m}$ east of S2. The fact that the pinnate remains are well preserved indicates that these plants were living at the time of the eruption, and were removed from the tree while still "fresh". The discovery of the foliage in the upper levels of the Bělka bed suggests that they fell from the crown of the tree fern a short time after the initial layer of volcanic ash was deposited (i.e., they were not part of the forest-floor litter), and probably broke off due to overloading by the weight of the volcaniclastics.

Arborescent tree ferns that occupied peat-forming mires during the Westphalian had a crown of large fronds, but probably only achieved heights of 3 to $4 \mathrm{~m}$ (Morgan, 1959; Lesnikowska, 1989). We thus consider the parent plant of Pecopteris aspidioides to be a component of the understorey in the Lower Radnice mire. Such plants were "cheaply" constructed and had a massive reproductive output, which allowed for widespread dispersal and rapid colonisation of available habitats. Psaronius tree ferns apparently occupied peat that was periodically or completely exposed during the early stages of growth, but were probably able to tolerate fluctuations in the water table once the root mantle had fully developed (DiMichele and Phillips, 2002).

Corynepteris angustissima (Sternberg) Němejc (1938).

The remains of this zygopterid fern were represented by small pinnate frond fragments, thorny phyllophores ranging from a few to $20 \mathrm{~mm}$ in diameter, and fertile organs that were scattered across much of the central part of the excavation (Fig. 12; Plate VII, Figs. 2, 2a; Plate VIII). They covered $5.3 \mathrm{~m}^{2}(10.6 \%)$ of the surface (Table 2 ), and most of the remains occurred at or very near the base of the Bělka bed. A particularly informative find was in unit 1E5 in the northeastern corner of S2, where phyllophores with attached pinnate foliage were discovered in life position climbing an upright "Lepidodendron" simile trunk (Plate VIII, Figs. 1, 2). This was observed ca. $750 \mathrm{~mm}$ above the base of the coal seam, and thus was in the Brousek part of the Whetstone Horizon.

Interpretation: The randomly scattered clusters of this fern indicates that several plants may have existed as understorey or ground cover elements, although it is not possible to specify the number of plants or where they lived. They may have grown in small patches, and shared more open (less shaded) portions of the mire surface with other ground cover species, particularly Sphenophyllum cf. majus (Opluštil et al., 2007). This interpretation is consistent with the almost complete absence of remains of Corynepteris angustissima (and S. cf. majus) in the northern part of S2, where the lower levels of the forest were strongly shaded by the canopy of a cordaitalean tree.

The habit, reproductive strategy and a reconstruction of Corynepteris angustissima are currently being studied, based in part on specimens gathered from these excavations (Pšenička, 2006). It may have been similar in habit to many other zygopterid ferns, which are characterised by slender, erect fronds borne on rhizomes that crept along the forest floor (DiMichele and Phillips, 2002; Galtier, 2004; Phillips and Galtier, 2005). Although the fronds of $C$. angustissima apparently were small and only reached a few 100s of $\mathrm{mm}$ in size, the spiny phyllophore is comparatively robust (up to $20 \mathrm{~mm}$ ), which indicates that it was rather tall and had evolved adaptations for clinging to or climbing adjacent vegetation. 
Desmopteris longifolia (Sternberg in Göppert) Stur (1885).

This zygopterid fern was represented by a few isolated ultimate pinnae, not longer than $100 \mathrm{~mm}$, in unit C4 of S1 (Fig. 12; Plate VII, Fig. 3). They cover only $0.2 \mathrm{~m}^{2}$, or $0.4 \%$ of the excavation area.

Interpretation: A solitary plant was probably growing in the area of excavation, and it most likely represents a ground cover or understorey plant. The presence of only a few small, pinnate remains indicates that the parent plant was either a juvenile, or that the species was of small stature. Libertín et al. (2009-this volume) considered Desmopteris alethopteroides (a similar if not conspecific taxon) to be a creeping plant, with erect, foliage-bearing phyllophores borne from procumbent rhizomes.

Hymenotheca sp. Potonié (1892).

A few, tiny ultimate pinnae from fronds of this small fern were found in unit C1 of S1 (Fig. 13; Plate VII, Figs. 4, 5), covering only $0.2 \mathrm{~m}^{2}$ $(0.4 \%)$ of the excavation surface.

Interpretation: It is probable that a single, small plant grew in the study area. The pinnae fragments were found close to two upright stems with small diameters, which indicates that this poorly understood plant may have been a climber or part of the ground cover.

Sphenopteris sp. (Brongniart) Sternberg (1825).

A number of isolated frond fragments of this species were found in S1, but most were clustered in units A1-2 and adjacent B1-2 (Fig. 13; Plate VII, Fig. 6). The remains of this species covered $1.6 \mathrm{~m}^{2}$, or $3.2 \%$ of the excavation surface (Table 2), and occurred between 100 and $350 \mathrm{~mm}$ above the base of the Bělka bed.

Interpretation: The clustered distribution of pinnate foliage of this taxon suggests that a single plant was growing in the northwestern corner of S1. Although members of the morphotaxon Sphenopteris belong to several groups of plants, including true ferns and pteridosperms, this particular species is thought to be the foliage of a pteridosperm based on its similarity to Palmatopteris. Unfortunately, nothing of its growth habit is known. However, the fact that it has a fairly wide although clustered distribution, both vertically and laterally, suggests that this plant was part of the ground cover component of the forest.

Sphenopteris mixta Schimper (1869).

Several small fragments of penultimate and ultimate pinnae were found scattered on either side of the border between S1 and S2. They were concentrated near the non-excavated promontory in the northwestern corner of S1 (Fig. 13; Plate IX, Fig. 2). Several other remains appeared about 2.5 to $3 \mathrm{~m}$ to the northeast. This species had a low representation, covering only $1.2 \mathrm{~m}^{2}$ or $2.4 \%$ of the excavation.

Interpretation: A solitary or small group of plants evidently grew in the northwestern corner of S1. The fragments outside of this cluster in the eastern part of S2 may also have been derived from this plant(s), although they may indicate the presence of another individual just beyond the eastern margin of S2. As with the previous taxon, we lack evidence on the growth habit of this pteridosperm, but believe that it was a ground cover element.

Laveineopteris loshii (Brongniart) Cleal, Shute \& Zodrow, (1990).

This species was represented by ultimate and penultimate pinnae fragments, some of which were still attached to smooth rachises reaching over $1 \mathrm{~m}$ in length. All of the remains were found in the northwestern part of S1, where they surrounded a $150 \mathrm{~mm}$ wide upright stem with aerial roots (Fig. 14; Plate VII, Figs. 7, 8). Another smaller stump (50 $\mathrm{mm}$ in diameter) with aerial roots was also found in the vicinity in unit A1. No seeds or pollen organs were found. Most of the frond fragments occurred from 350 to $500 \mathrm{~mm}$ above the base of the tuff bed, however, some were found at, or a few $10 \mathrm{~s}$ of $\mathrm{mm}$ above, the base. The remains of Laveineopteris loshii covered an oval area about $4 \times 3 \mathrm{~m}$ in size $\left(8.0 \mathrm{~m}^{2}\right.$ or $16 \%$ of the excavation), with the largest parent stem in the centre (unit B2).

Interpretation: The distribution of foliar and axial remains of this species indicates that two adjacent plants were rooted about $1.2 \mathrm{~m}$ apart. The erect axes are interpreted as the monoaxial stems of $\mathrm{Me}$ - dullosa, which bore a crown of large fronds. The oval area of dispersion of foliage around the largest upright stem suggests that this plant had ca. $2 \mathrm{~m}$ long fronds. Fronds of the smaller erect axis presumably overlapped those of the larger plant. The absence of seeds or pollen organs suggests that both plants had yet to reach sexual maturity, or were not in a reproductive phase. The smaller specimen may have been a juvenile. The quality of preservation, together with the organic connection of foliage and rachises in some cases, points to these plants being alive at the time of the eruption, with branches simply broken from the crown and scattered around their stems due to overloading.

Westphalian medullosan pteridosperms centered in peat-forming swamps likely were of shorter stature than those growing on clastic substrates (DiMichele and Phillips, 1994; DiMichele et al., 2006), and probably reached heights ranging from 3 to $5 \mathrm{~m}$ (Steward and Delevoryas, 1956). Laveineopteris loshii thus probably formed part of the understorey component of the Lower Radnice Coal. Medullosans bore large seeds and had a low reproductive output, features that suggest a reproductive phase extending several seasons and relatively long life spans (DiMichele et al., 2006). Furthermore, the large seed size resulted in germination of new saplings close to the parent plant, causing thickets to form (Shute and Cleal, 2002), which may explain the observation of two plants in close proximity in the excavation. Medullosan remains from mires are most commonly associated with mineral partings in coal seams, and tend to be part of high diversity assemblages that include ground cover species, such as small ferns (DiMichele and Phillips, 1988, 1994). These previous observations are all in accord with the swamp conditions and taxonomic spectrum interpreted for the Lower Radnice Coal.

Eusphenopteris nummularia (Gutbier) Novik (1947).

This was the most common plant in the excavation with a known liana habit. Its remains had their highest concentration in several units of S2 (1B3-4 and 1C3-4 and parts of adjacent units) (Fig. 15). Here, ultimate pinnae fragments and several $10 \mathrm{~s}$ of rachises with or without attached pinnules were discovered 180 to $450 \mathrm{~mm}$ above the tuff base (Plate IX, Figs. 5-7). The largest axis was about $1 \mathrm{~m}$ long, and most rachises pointed towards the eastern margin of the excavation at an azimuth of $80^{\circ}$, although several were perpendicular to this direction. Outside of this largest concentration, the remains of E. nummularia were found in small clusters scattered throughout the excavation, although they accounted for less than $1 \mathrm{~m}^{2}$ of the total area covered by this species $\left(9.2 \mathrm{~m}^{2}\right.$ or $\left.18.4 \%\right)$ (Table 2). The distance between neighboring occurrences varied between 1.2 and $2.5 \mathrm{~m}$.

Interpretation: Eusphenopteris nummularia was a lyginopterid pteridosperm with a facultative climbing habit, and fronds arose from a stem that may not have been self-supporting (DiMichele et al., 2006). The distribution of this species in the excavation signifies the existence of at least one individual plant near the centre of S2, and the size and number of rachises indicates that its fronds reached up to $2 \mathrm{~m}$ in length. The nearest upright stems of arborescent plants, to which this liana could have entwined or clung to for support, are located just outside the main concentration of frond fragments - the "Lepidodendron" simile stump in unit 1B2 (S2) and the tall Lepidophloios cf. acerosus trunk in unit 1A4 (S2) are the most likely candidates. Key to this interpretation is the presence of narrow $(<100 \mathrm{~mm})$ diameter stems immediately beside both of these lycopsid stumps, and it is plausible that one of these actually represents the bottom, rooted portion of the liana. Gastaldo et al. (2004b) stated that some lyginopterid pteridosperms first began as a prostrate stem that crept along the forest floor, only to become lianas once a suitable supporting agent was encountered. Accordingly, the small clusters of $E$. nummularia foliage that were found close to the base of the tuff bed may have been creepers that formed part of the ground cover component of the mire, and which were immediately buried when the ash fell (e.g., occurrences in units E4-5 (S1); C2 and D2 (S1); B1 and C1 (S1)). In contrast, the foliar remains discovered in higher levels of 
Table 1

\begin{tabular}{|c|c|c|c|c|c|c|}
\hline & Plant groups & & & Species & $\mathrm{S} 1$ & $\mathrm{~S} 2$ \\
\hline 1 & Lycopsida & Arborescent & Cone & Flemingites sp. & + & + \\
\hline 2 & & forms & & Lepidostrobus sp. & + & + \\
\hline 3 & & & Stems & Lepidodendron simile & + & + \\
\hline 4 & & & & $\begin{array}{l}\text { Lepidodendron } \\
\text { lycopodioides }\end{array}$ & + & \\
\hline 5 & & & & Lepidophloios cf. acerosus & + & + \\
\hline 6 & & & & Lepidodendron longifolium & & + \\
\hline 7 & & Sub-arborescer & t forms & Spencerites havlenae & + & \\
\hline 8 & & Herbaceous for & & $\begin{array}{l}\text { Herbaceous bisporangiate } \\
\text { lycopsid }\end{array}$ & & + \\
\hline 9 & Sphenopsida & Calamites & $\begin{array}{l}\text { Leafy } \\
\text { shoots }\end{array}$ & Asterophyllites sp. & + & \\
\hline 10 & & & Cones & Palaeostachya gracilima & + & \\
\hline 11 & & & Stems & Stylocalamites sp. & + & + \\
\hline 12 & & Sphenophylls & & Sphenophyllum cf. majus & + & + \\
\hline 13 & & & & $\begin{array}{l}\text { Sphenophyllum } \\
\text { pseudoaquense }\end{array}$ & + & + \\
\hline 14 & Filicopsida & Marattialean $\mathrm{fe}$ & rns & Pecopteris aspidioides & + & + \\
\hline 15 & & Zygopterid ferr & & Corynepteris angustissima & + & + \\
\hline 16 & & & & Desmopteris longifolia & + & \\
\hline 17 & & Other ferns & & Hymenotheca sp. & + & \\
\hline 18 & $\begin{array}{l}\text { Pterido- } \\
\text { spermopsida }\end{array}$ & $\begin{array}{l}\text { Medullosalean } \\
\text { pteridosperms }\end{array}$ & & Laveineopteris loshii & + & \\
\hline 19 & & Lyginopterid & & Sphenopteris mixta & + & + \\
\hline 20 & & pteridosperms & & Mariopteris muricata & + & + \\
\hline 21 & & & & Palmatopteris furcata & + & \\
\hline 22 & & & & $\begin{array}{l}\text { Eusphenopteris } \\
\text { nummularia }\end{array}$ & + & + \\
\hline 23 & & & & Sphenopteris sp. & + & \\
\hline 24 & Cordaitopsida & Cordaitaleans & Cones & Cordaianthus sp. & & + \\
\hline 25 & & & Seeds & Cardiocarpus sp. & + & \\
\hline 26 & & & Leaves & Cordaites borassifolius & + & + \\
\hline 27 & & & $\begin{array}{l}\text { Stem } \\
\text { casts }\end{array}$ & Artisia sp. & + & + \\
\hline \multicolumn{4}{|c|}{ Number of morphotaxa } & $\begin{array}{l}\text { Excavations separately } \\
\text { S1 and S2 }\end{array}$ & $\begin{array}{l}24 \\
27\end{array}$ & 17 \\
\hline \multirow{2}{*}{\multicolumn{4}{|c|}{ Estimated number of biological species }} & Excavations separately & 18 & 13 \\
\hline & & & & S1 and S2 & 20 & \\
\hline \multirow{2}{*}{\multicolumn{4}{|c|}{ Area of sampling $\left(\mathrm{m}^{2}\right)$}} & Excavations separately & 25 & 25 \\
\hline & & & & $\mathrm{S} 1$ and S2 & 50 & \\
\hline
\end{tabular}

the ash represent litter that was broken from lianescent plants occupying the forest canopy. The very consistent orientation of rachises in the largest cluster of $E$. nummularia remains strongly supports the interpretation that much of this litter fell together as a single clump under the weight of volcanic ash.

Mariopteris muricata (Brongniart) Zeiller (1879).

Ultimate and penultimate frond fragments (Plate IX, Figs. 3, 4) and naked rachises of this pteridosperm species were concentrated in two adjacent areas near the border of both excavations, and are separated by an unexcavated promontory in the northwestern corner of S1 (Fig. 16). A few other scattered remains occur within $1.5 \mathrm{~m}$ of these two clusters. This species is found in the upper parts of the Bělka bed ( 300 to $450 \mathrm{~mm}$ above the base), and covers $3.3 \mathrm{~m}^{2}$ (6.6\%) of the excavated area (Table 2).

Interpretation: Many mariopterid pteridosperms had scrambling or climbing habits, with small fronds that were equipped with terminal extensions of pinnae axes (Boersma, 1972) or specialised recurved hooks on the abaxial side of pinnules (Krings et al., 2001). These fronds arose from narrow axes that required the support of adjacent vegetation to rise above the forest floor (Krings et al., 2003). In keeping with this theme, the discovery of numerous hairs on the upper surface of Mariopteris muricata pinnules by Barthel (1962) could be considered as evidence for a xeromorphic, climbing habit for this species (DiMichele et al., 2006). Accordingly, it is not surprising that frond elements in the excavation tended to occur in proximity to erect stems, such as the unidentified axis in $1 \mathrm{~A} 1$ (S2), and the unidentified axis and adjacent Lepidophloios cf. acerosus stump in CO (S1). These two unidentifiable stems, which are situated about $2 \mathrm{~m}$ apart, may have been the parent axes of separate $M$. muricata plants. However, given the fact that such stems were probably not selfsupporting, it may be that the unidentifiable axis in C0 (S1), which was directly adjacent to a $L$. cf. acerosus stump, was the rooted vine to which both clusters of foliar remains belonged. This scenario is plausible since all of the $M$. muricata remains were closely associated with Halonia-type branches of $L$. cf. acerosus, and may have fallen together from this lycopsid under the weight of volcanic ash. If so, this interpretation infers that $L$. cf. acerosus remained in its terminal, reproductive phase at least long enough that vines already entwining the main stem were able to reach parts of its dichotomising "crown".

Palmatopteris furcata (Brongniart) Potonié (1891).

This pteridosperm species was represented by small frond fragments (Plate IX, Fig. 1) that displayed a distribution similar to that of Mariopteris muricata, although it only covered $1.8 \mathrm{~m}^{2}$ (3.6\%) of the excavation surface (Fig. 11). There were two adjacent occurrences separated by $1.5 \mathrm{~m}$ in the northern part of $\mathrm{S} 1$, where several erect stems were also located. Nearly all the remains occurred between 300 and $400 \mathrm{~mm}$ above the roof of the coal seam. Only very few isolated fragments were discovered at the base of the Bělka bed in unit C5 along the southern margin of S1.

Interpretation: It is probable that one or two plants grew in the central part of the excavation. Co-occurrence in the upper part of the Bělka bed with Mariopteris muricata may indicate a similar lianescent growth habit and burial history, with both species possibly vines on the same Lepidophloios cf. acerosus tree. Stidd and Phillips (1982) documented anatomically preserved foliage similar to Palmatopteris attached to the small pteridosperm Johnhallia, a possible relative of Callistophyton, but the habit of this plant is unknown.

Cordaites borassifolius (Sternberg) Unger (1850).

Isolated leaves, leaf-bearing and leafless branches, male and possibly female cones, seeds, and Artisia pith casts were irregularly distributed over $38.0 \mathrm{~m}^{2}$ (76.0\%) of the excavated area (Fig. 17; Plate X). Remains of this species were the most common fossils in the tuff bed in S2, where isolated leaves and branches $10 \mathrm{~s}$ of $\mathrm{mm}$ wide were profuse in the basal $50 \mathrm{~mm}$ everywhere but along the southern margin (patterned area in Fig. 17). The concentration of $C$. borassifolius organs in this layer increased towards the northern part of S2, where a large axis at least $150 \mathrm{~mm}$ wide (true diameter not known) was preserved. In S1, cordaitalean remains were much less common in the corresponding basal part of the Bělka bed. Here, isolated or groups of leaves and branch fragments reaching over $2 \mathrm{~m}$ long were more common in the middle and upper levels of the Bělka bed. A $5.7 \mathrm{~m}$ long prostrate trunk that was $450 \mathrm{~mm}$ in diameter near its base crossed S1 from its northwestern corner towards the east-southeast. This tree bore several branches, which were always narrower than the main stem. Unfortunately, the stem was leafless, which makes its determination less reliable, although its size, surface texture, the

\section{Plate I.}

Fig. 1.

Fig. 2.

Fig. 3.

Fig. 4.

Fig. 5.

Fig. 6.
Prostrate lepidodendrid ("Lepidodendron" simile) stem in S2 showing dichotomous branching (branches indicated by arrows). View of the stem in Fig. 1 showing another branch pointing down to the coal seam (indicated by arrow).

Detail of the surface of the prostrate stem from Figs. 1 and 2. The sample from the lower part of the stem is decorticated and only shows an outline of the leaf cushions.

Exposed surface of the tuff bed with fragments of "Lepidodendron" simile leafy shoots and cones (c) associated with a Sphenophyllum cf. majus axis (Sm). Detail of the leaf cushions of "Lepidodendron" simile with false leaf scars. Infrafoliar parichnos traces are absent.

Branch of "Lepidodendron" simile. 

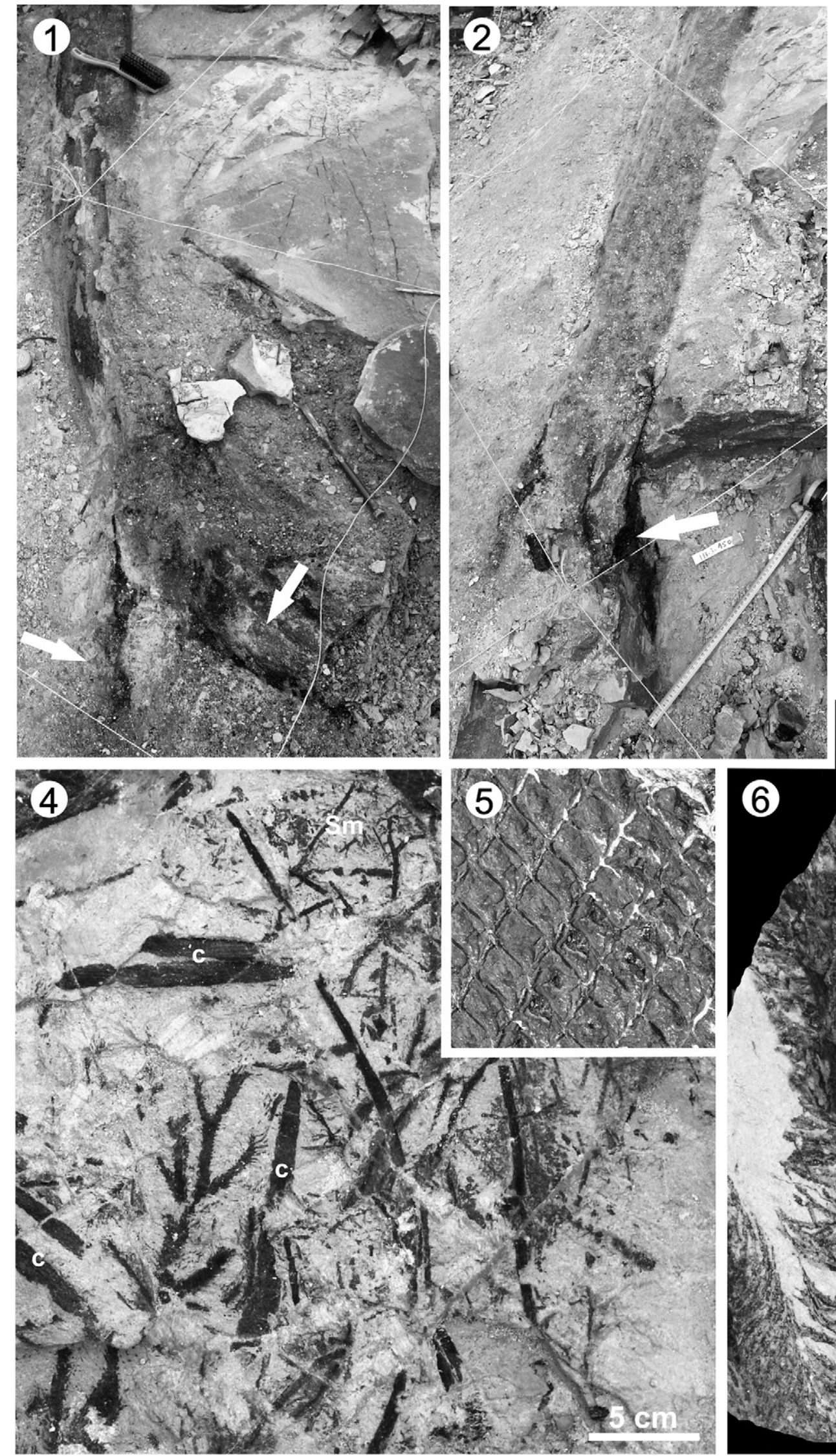

$3 /$ hind

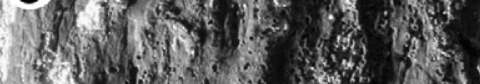
3) 130 by

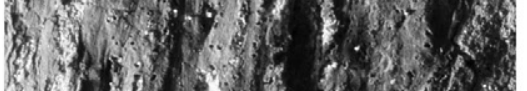

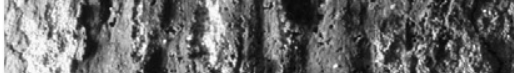
b) In 3 \% $19 \%$. (1) in

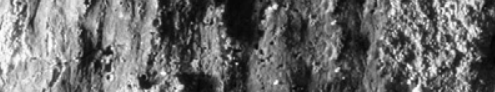

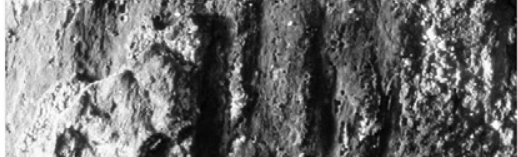

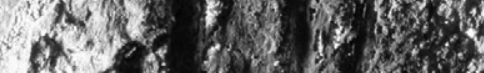
370,1
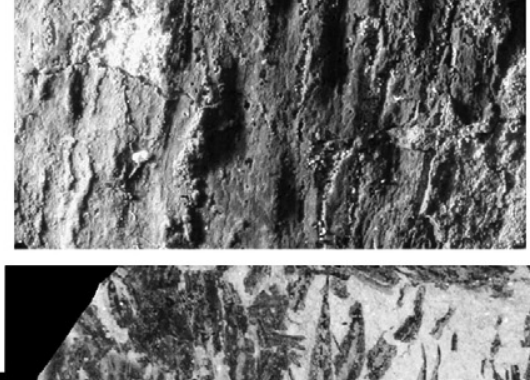
(1)

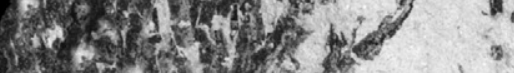
Atiogers 1 of - I.

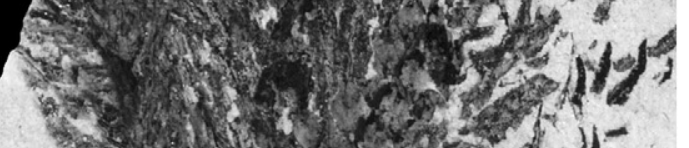
5. (1)

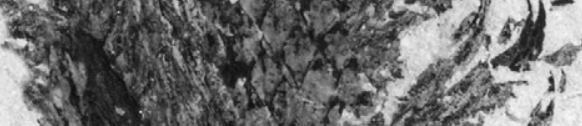

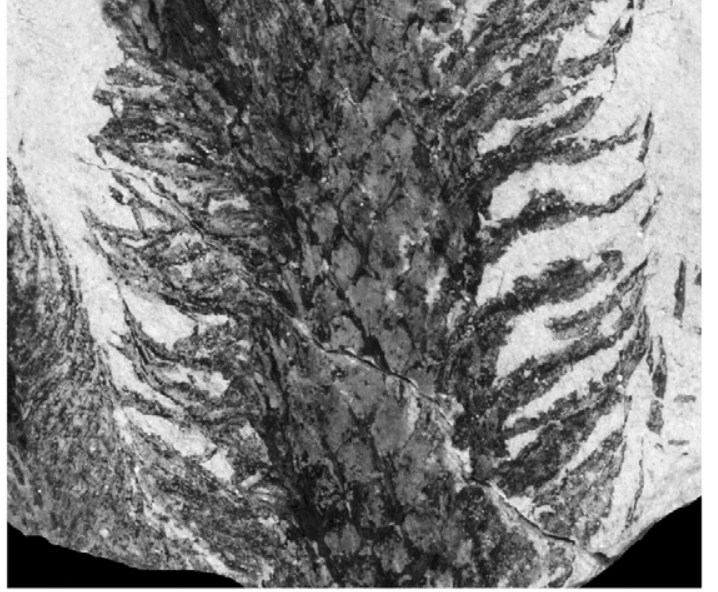


Table 2

\begin{tabular}{|c|c|c|c|c|}
\hline Species & Habit & $\begin{array}{l}\text { Area } \\
\left(\mathrm{m}^{2}\right)\end{array}$ & $\begin{array}{l}\text { Percentage } \\
\text { cover }(\%)\end{array}$ & $\begin{array}{l}\text { Normalised } \\
\text { contribution (\%) }\end{array}$ \\
\hline Cordaites borassifolius & Canopy & 38.0 & 76.0 & 26.7 \\
\hline "Lepidodendron" simile & Canopy & 35.0 & 70.0 & 24.6 \\
\hline $\begin{array}{l}\text { Lepidophloios } \mathrm{cf} . \\
\text { acerosus }\end{array}$ & Canopy & 18.5 & 37.0 & 13.0 \\
\hline $\begin{array}{l}\text { Eusphenopteris } \\
\text { nummularia }\end{array}$ & Liana & 9.2 & 18.4 & 6.5 \\
\hline Laveineopteris loshii & Understorey & 8.0 & 16.0 & 5.6 \\
\hline Sphenophyllum cf. majus & Ground cover & 6.5 & 13.0 & 4.6 \\
\hline $\begin{array}{l}\text { Sphenophyllum } \\
\text { pseudoaquense }\end{array}$ & Liana & 6.5 & 13.0 & 4.6 \\
\hline $\begin{array}{l}\text { Corynepteris } \\
\text { angustissima }\end{array}$ & Ground cover & 5.3 & 10.6 & 3.7 \\
\hline Pecopteris aspidioides & Understorey & 4.8 & 9.6 & 3.4 \\
\hline Mariopteris muricata & Liana & 3.3 & 6.6 & 2.3 \\
\hline Palmatopteris furcata & Liana & 1.8 & 3.6 & 1.3 \\
\hline Sphenopteris sp. & Ground cover & 1.6 & 3.2 & 1.1 \\
\hline Sphenopteris mixta & Ground cover & 1.2 & 2.4 & 0.8 \\
\hline $\begin{array}{l}\text { Herbaceous } \\
\text { bisporangiate lycopsid }\end{array}$ & Ground cover & 0.6 & 1.2 & 0.4 \\
\hline $\begin{array}{l}\text { Lepidodendron } \\
\text { lycopodioides }\end{array}$ & Canopy & 0.6 & 1.2 & 0.4 \\
\hline $\begin{array}{l}\text { Lepidodendron } \\
\text { longifolium }\end{array}$ & Canopy & 0.4 & 0.8 & 0.3 \\
\hline Spencerites havlenae & Understorey & 0.4 & 0.8 & 0.3 \\
\hline Stylocalamites sp. & Understorey & 0.4 & 0.8 & 0.3 \\
\hline Hymenotheca sp. & Ground cover & 0.2 & 0.4 & 0.1 \\
\hline Desmopteris longifolia & Ground cover & 0.2 & 0.4 & $\begin{array}{l}0.1 \\
\text { Total }=100.0 \%\end{array}$ \\
\hline
\end{tabular}

character of branching, and accompanying leaves of $C$. borassifolius point to the conclusion that it represented a tree of this species. In the northwestern corner of S1, the stem was about $100 \mathrm{~m}$ above the top of the coal seam, but it gradually inclined towards its distal end such that on the opposite side of S1 it was $200 \mathrm{~mm}$ above the coal seam and only $150 \mathrm{~mm}$ in diameter. The stem is evidently incomplete, and it undoubtedly continued some metres beyond the northwestern and eastern margins of the excavation. It was likely rooted in the coal seam towards the northwest, where a nearly $2 \mathrm{~m}$ long apical branch was found next to the main stem (Plate X).

Interpretation: The distribution of Cordaites borassifolius remains indicates the presence of at least two plants situated in proximity to the study area. The individual preserved in the northern part of S2 was probably a large mature (?male) tree situated beyond the presumed northern margin of the excavation. The tree in S1 was also large, and according to the formula of Niklas (1994), the predicted height would have been at least $27.1 \mathrm{~m}$ ( $\mathrm{DBH}>450 \mathrm{~mm})$. However, a height of this magnitude seems unlikely. What is exposed of the main axis exhibits a rapid decrease in girth distally (from 450 to $150 \mathrm{~mm}$ over a length of just $5.7 \mathrm{~m}$ ) due to sympodial branching. Accordingly, we speculate that the tree was on the order of 15 to $20 \mathrm{~m}$ in height. Sympodial branching apparently began only a few metres from the base of the tree, resulting in a plant that probably had a laterally and vertically wide crown with a dense covering of leaves. Although some C. borassifolius leaves were associated with this tree, they were sparse in comparison with the individual in S2. This observation, in combination with the fact that all of the branches were leafless, points to the conclusion that this tree had already fallen prior the eruption. The few remaining attached leaves would have abscised after the volcanic ash fell.

Cordaitalean plants in Westphalian mires had a variety of growth forms and ecological preferences, including scrambling ground cover and trees occupying a variety of peat substrates (Raymond, 1988). These plants had the slowest growth and longest lives of all arborescent peat-forming vegetation, and thus probably preferred mires where disturbance was limited (DiMichele and Phillips, 1994).

\section{Plate II.}

Fig. 1. Lepidodendron longifolium. Upper part of excavated stem with grass-like leaves still attached. For scale see $1 \mathrm{~m}^{2}$ units indicated by string.

Fig. 2. Bark of Lepidodendron longifolium from more basal part of the exposed stem. Leaves are absent. For scale see $1 \mathrm{~m}^{2}$ units indicated by string.

Fig. 3. Detail of leaf cushions of Lepidodendron longifolium from Fig. 2. 3x.

Fig. $4 . \quad$ Leafy shoot of Lepidodendron lycopodioides.

Fig. $5 . \quad$ Detail of leafy shoot of Lepidodendron lycopodioides. $3 \times$.

Fig. 6. Spencerites havlenae. Fragment of sterile axes.

Fig. 7. Herbaceous bisporangiate lycopsid. Sterile leafy axes in organic connection with bisporangiate cone.

Plate III. (see on page 256)

Fig. 1. Upright stem of Lepidophloios cf. acerosus in unit C0 of S1.

Fig. 2. Halonia-type branch with two attached male cones (c). Arrows indicate the site of cone attachment. Unit 1A1 (S2).

Fig. 3. Two large specimens of Halonia-type branches (h) with attached shoots and cones (c). Units 1C0-1 and 1D0-1 (S2).

Fig. $4 . \quad$ Detail of male cone of Lepidophloios cf. acerosus.

Fig. $5 . \quad$ Detail of bark of branch of Lepidophloios cf. acerosus.

Plate IV. (see on page 257)

Fig. 1. Large Lepidophloios cf. acerosus stump in unit C0 (S1). Arrows indicate Halonia-type branches scattered in the upper part of the Bělka bed.

Fig. 2. The same stump as in Fig. 1.

Fig. 3. Halonia-type branch (h) with "Y" shaped branching associated with a "Lepidodendron" simile branch. Units 1A1 and 1B1 (S2).

Fig. 4. Halonia-type branch (h) with "T" shaped branching. Unit 1C3 (S2).

Plate V. (see on page 258)

Fig. 1. Stylocalamites stem with branch scars.

Fig. 2. Calamitean pith cast.

Fig. 3. Sphenophyllum cf. majus leafy axes in organic connection with a cone.

Fig. $4 . \quad$ Leafy axis of Sphenophyllum $\mathrm{cf}$. majus

Fig. 4a. Detail of leaves from Fig. $4.2 \times$

Fig. 5. Sphenophyllum cf. majus leafy axes with cone in association with Corynepteris angustissima frond fragments.

Fig. $6 . \quad$ Sphenophyllum cf. majus leafy axes in organic connection with cone. 

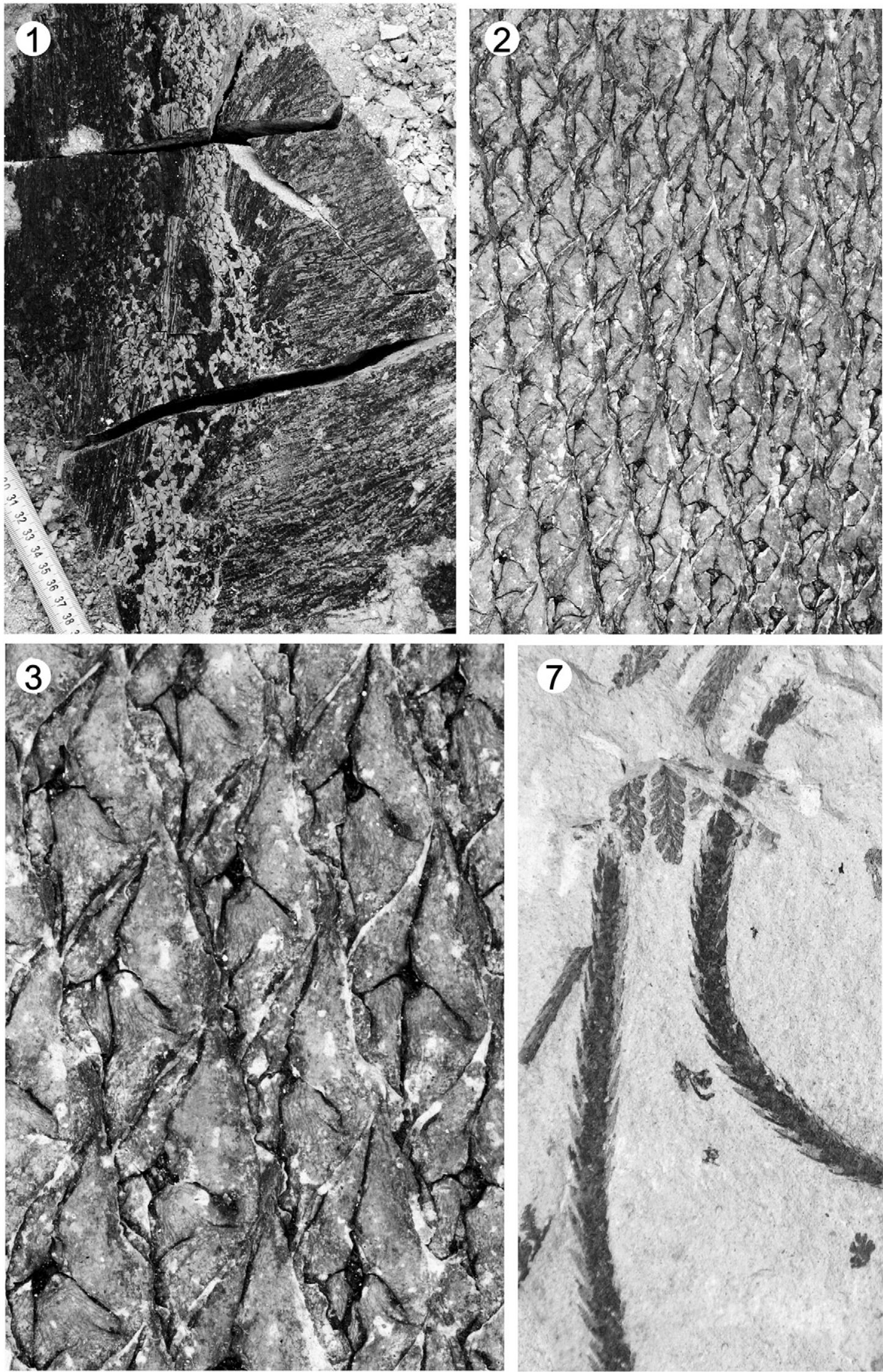

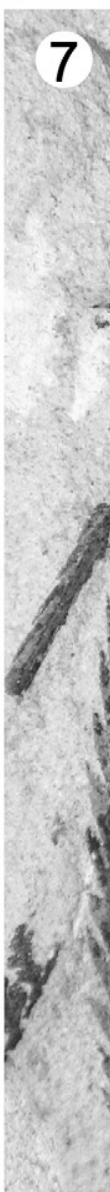

$-3) 3$ and
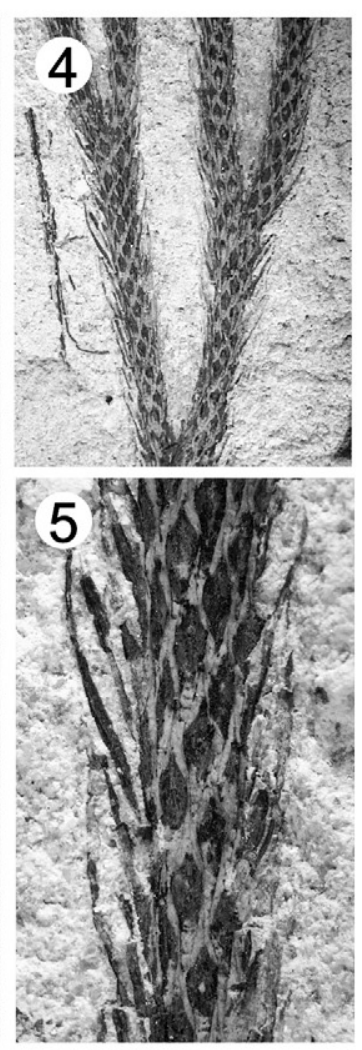

Acen of:

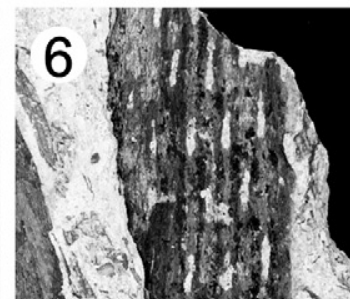

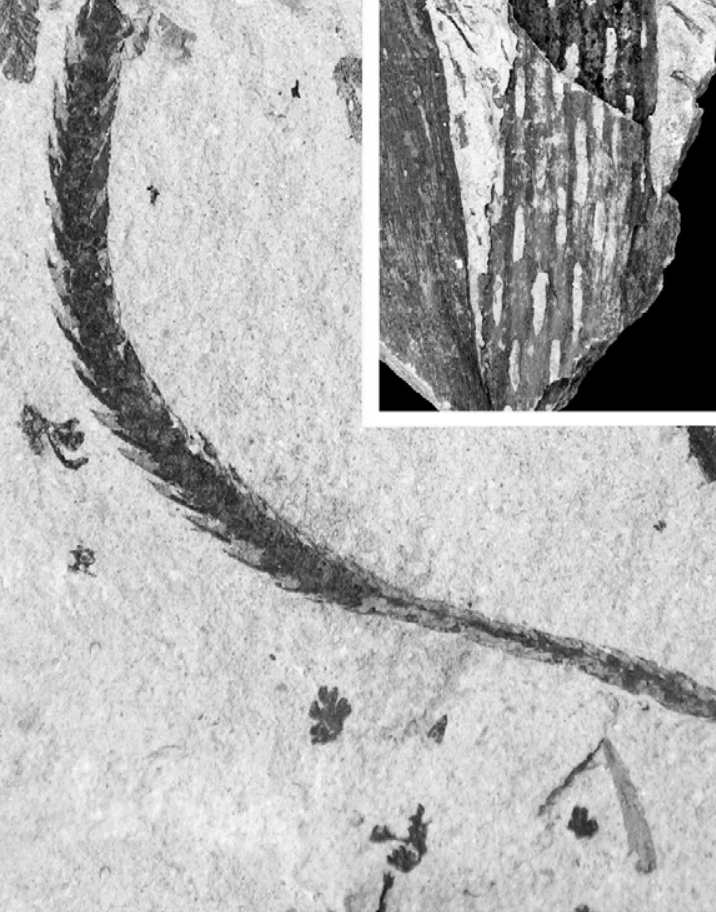




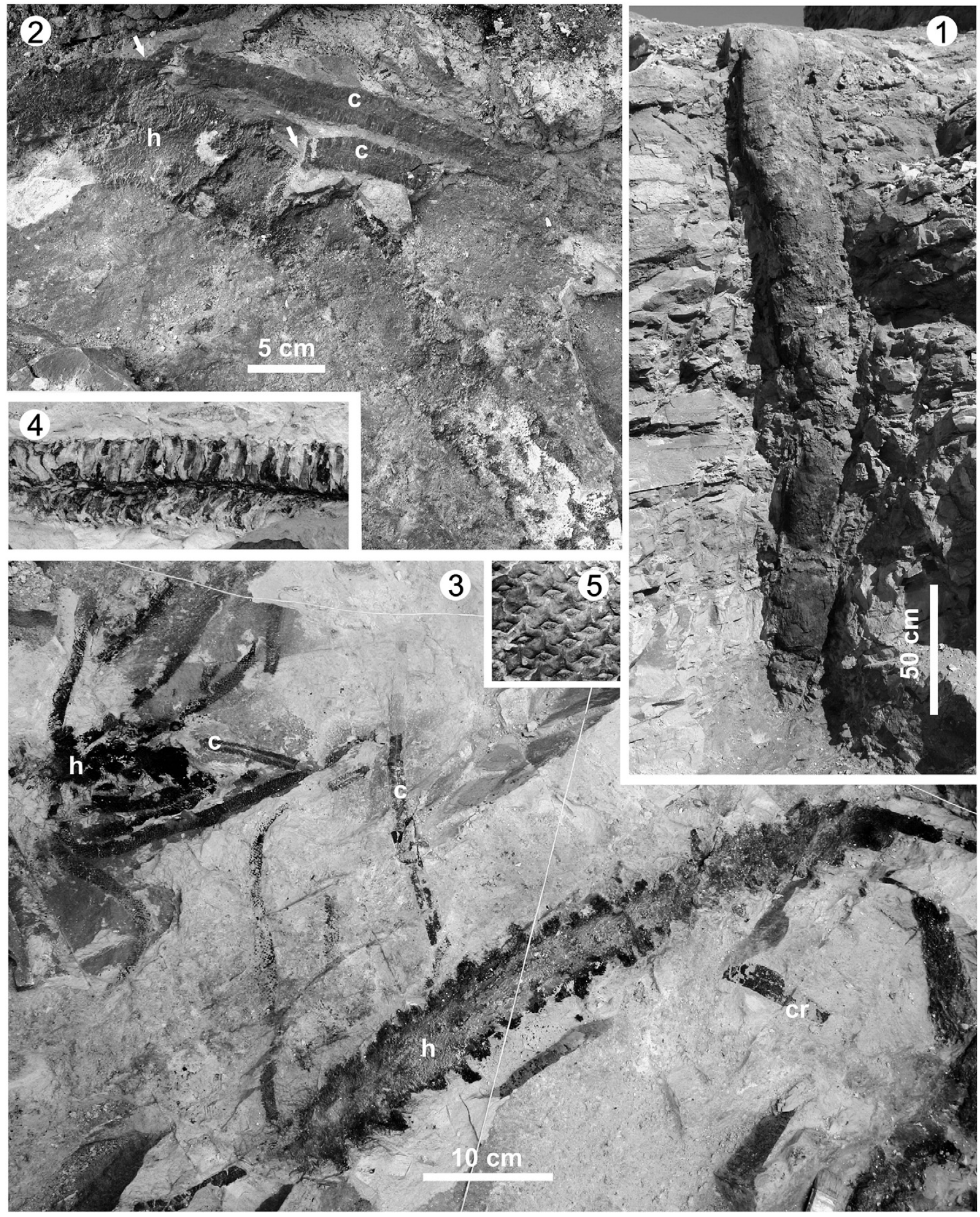



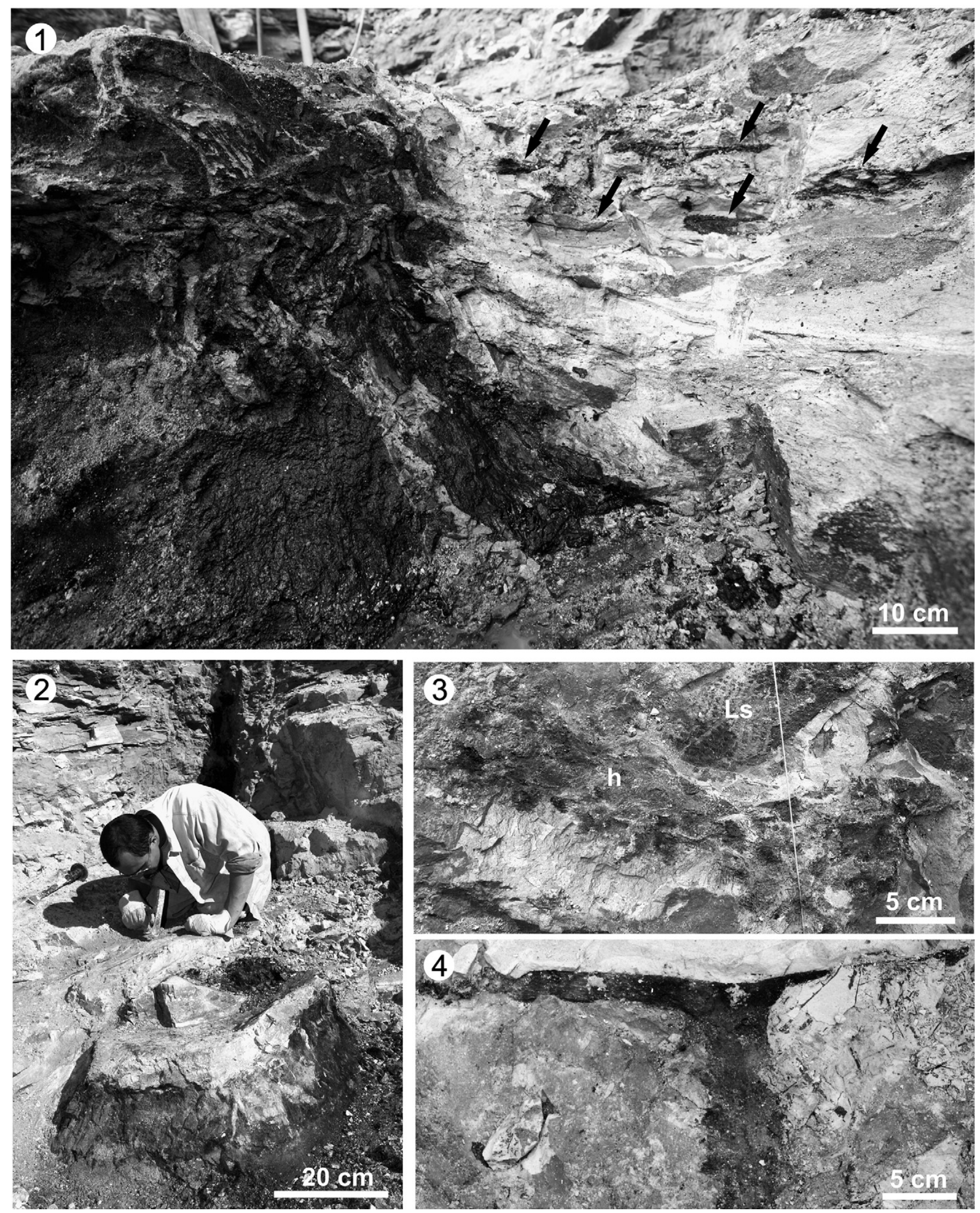


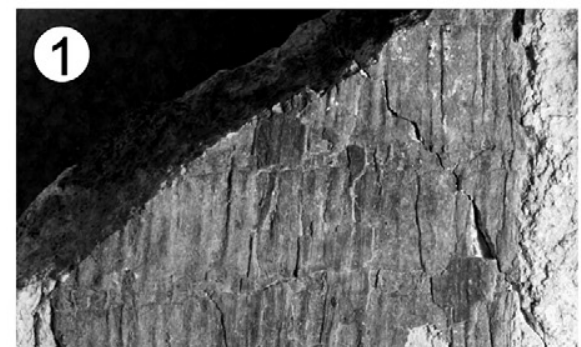

15u 1 vilut
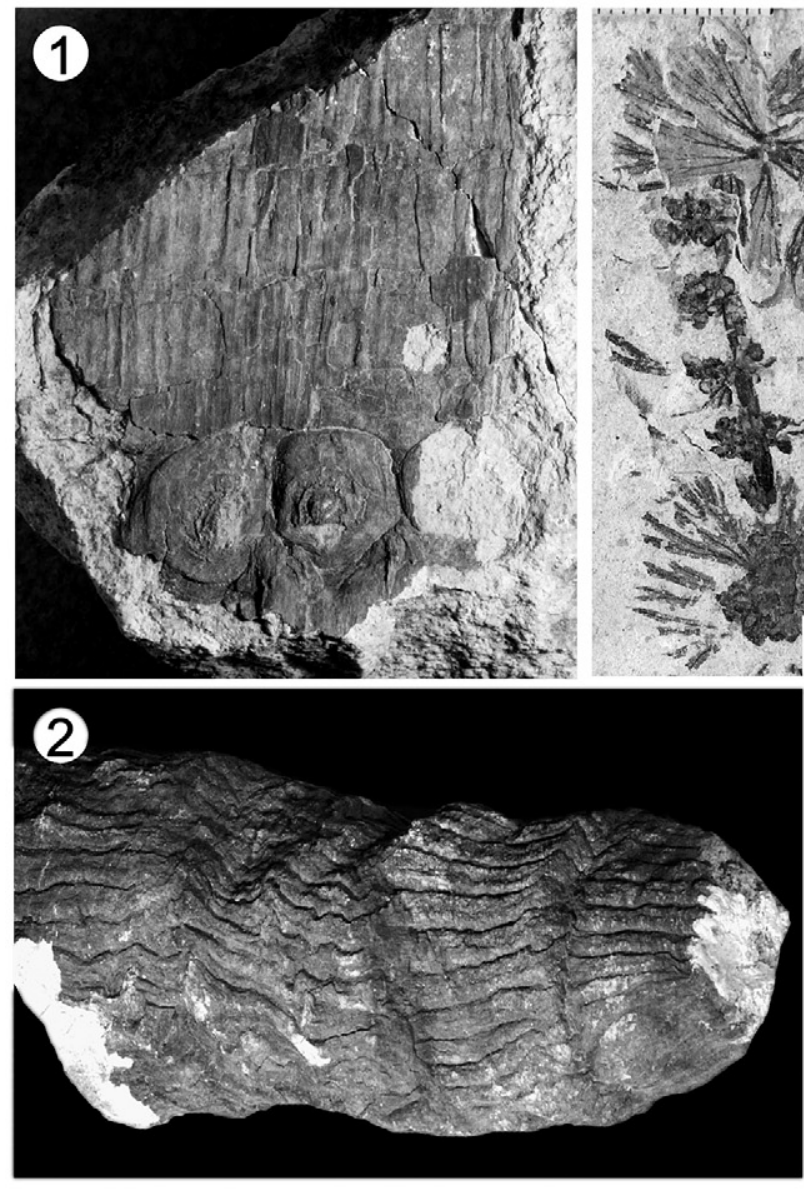

5

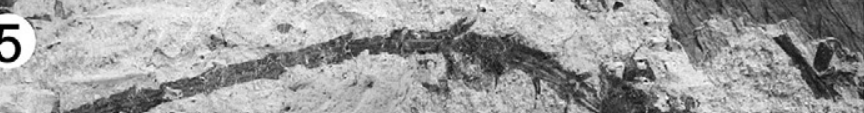

\section{(2) $1,12 x$}

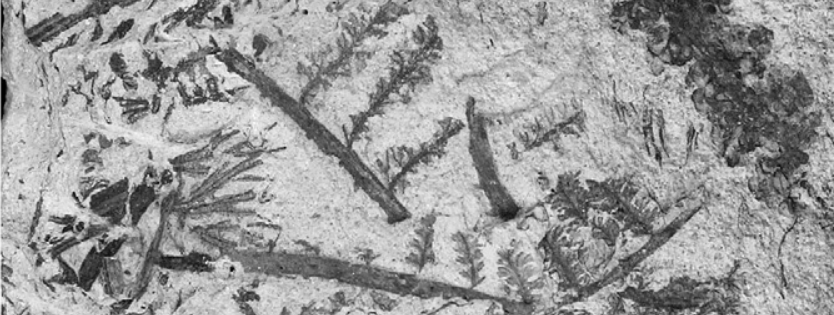

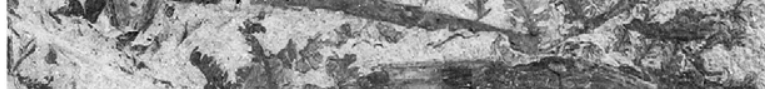
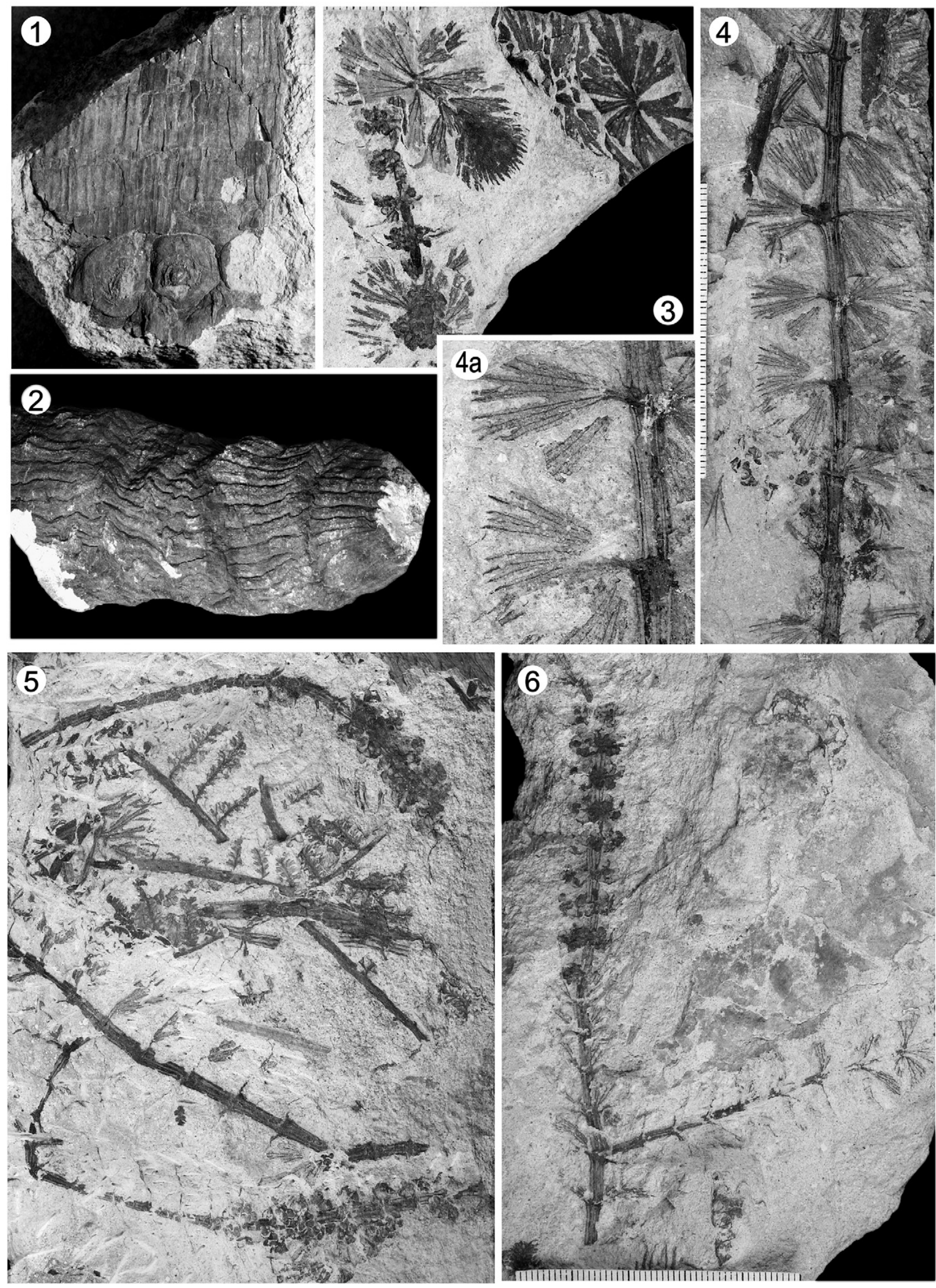
Nonetheless, many cordaitaleans are thought to have inhabited planar swamps that were subject to seasonally or periodically high water tables due to flooding (Calder, 1993; Eble and Grady, 1993).

\section{Characteristics of the phytocoenosis in the Sternberg excavations}

\subsection{Composition, density and distribution of forest storeys}

The plant species discovered in the excavations represent a wide variety of growth forms, which we separate into the following storeys: canopy, understorey, herbaceous ground cover that includes occasional climbers, and true lianas that in reality occupied the canopy (Table 2; Figs. 18-20).

\subsubsection{Canopy}

A total of $95 \%$ of the excavation surface was covered by the remains of arborescent taxa (Figs. 19, 20), comprising four species of lycopsids accompanied by Cordaites borassifolius. The latter was the most abundant taxon in the excavation, with a percentage cover of $76.0 \%$, whereas the dominant lycopsids were "Lepidodendron" (= Paralycopodites) simile and Lepidophloios cf. acerosus (70.0 and 37.0\%, respectively) (Table 2). Only a single individual of both Lepidodendron lycopodioides (unknown affinity; 1.2\%) and Lepidodendron longifolium (= Diaphorodendron or Synchysidendron; 0.8\%) were found, and the latter was probably a juvenile. The tallest trees in the excavated area and its immediate proximity belonged to $L$. cf. acerosus, with predicted heights of 22.5 to $30.0 \mathrm{~m}$. Mature trees of "L." simile reached 17.0 to $19.5 \mathrm{~m}$, and the $14.0 \mathrm{~m}$ L. longifolium tree might have attained a similar height when mature. The height of the fertile $L$. lycopodioides tree could not be calculated. Similarly, only a rough estimate of ca. 15.0 to $20.0 \mathrm{~m}$ is speculated for the $C$. borassifolius trees. The varying predicted heights indicate that a complex and vertically variable canopy existed in the mire, ranging between about 15 and $25 \mathrm{~m}$ above the floor of the peat-forming forest (Figs. 21, 23).

The remains of these canopy species occurred at all levels of the Bělka bed. However, their highest concentration was at or near the base of the unit, and they were very irregularly distributed in the middle and upper parts. This pattern indicates that the debris either represents pre-eruption forest litter, or plant organs broken from the parent plant immediately after the ash fell. Since there is no evidence of lateral transport, the area covered by the remains of a particular species is a proxy for the original outline of the tree crowns.

The distance between neighbouring trees varied between 2 and $3.5 \mathrm{~m}$ on average, based on the lateral spacing of erect stems in the excavation, or their interpreted growth position just outside the excavated area. Fig. 19 demonstrates that there was significant overlap between the most abundant species, with two and locally three taxa occurring together. These coalescing distributional zones commonly reached 2 to $3 \mathrm{~m}$ in width, and are interpreted to represent the actual overlap between tree crowns in the forest canopy. The height a mature individual could attain was probably biologically predetermined for each arborescent species, and thus the canopy was likely vertically heterogeneous. Lepidophloios cf. acerosus might have formed a discontinuous upper canopy with large gaps (Figs. 21, 23). In contrast, the lower part of the canopy contained several species that attained similar heights and thus was probably very compact (Figs. 19, 21, 23). It is important to reiterate that the arborescent lycopsids grew as tall, columnar trunks throughout most of their life cycle, and thus blocked negligible sunlight (DiMichele and Phillips, 1985; Phillips and DiMichele, 1992). Furthermore, the sparse lateral branches in some genera, and the determinate, reproductive "crown" of dichotomous branches in others, probably resulted in only diffuse shade, offering neighbouring or underlying vegetation unimpeded access to light. In this context, it is reasonable to assume that Cordaites borassifolius was capable of living side by side with the arborescent lycopsids without competing for available sunlight.
It is interesting to note that the only species growing in the northern part of S2 was Cordaites borassifolius (Fig. 19). The marked absence of any other taxa from other forest storeys suggests that the canopy of this plant comprised very dense foliage, resulting in a deep shade that precluded any other plants from growing beneath it.

\subsubsection{Understorey}

A total of $27 \%$ of the excavation surface was covered by four understorey species (Figs. 19, 20), all of which were probably less than $5 \mathrm{~m}$ in height. Of these, Laveineopteris loshii was the most common (percentage cover of $16.0 \%$ ), followed by Pecopteris aspidioides (9.6\%), and very rare remains of Stylocalamites sp. and Spencerites havlenae (both $0.8 \%$ ). Plant remains representing this habit were concentrated in the middle and upper parts of the Bělka bed, but also appeared at its base as part of the forest litter together with ground cover elements. The distribution of understorey vegetation is discontinuous, and mostly occurred as isolated or small clumps of plants (Figs. 19, 21, 23).

\subsubsection{Lianas}

Three species of lyginopterid pteridosperms found in the excavation are considered to be true lianas that used arborescent trees for support. Eusphenopteris nummularia had the greatest percentage cover (18.4\%), followed by Mariopteris muricata (6.6\%) and Palmatopteris furcata (3.6\%) (Table 2; Figs. 19, 20). Although stems of these species were never found wrapped around erect axes, their remains were generally found in the vicinity of upright stems and branches of "Lepidodendron" simile and Lepidophloios cf. acerosus trees, where they commonly co-occurred (Fig. 19). These lyginopterid pteridosperms may have grown together on the same tree, an interpretation that is in agreement with the discovery of several epiphytic and lianescent species around and within the outer root mantle of an individual tree fern (Rößler, 2000). Most fronds and rachises were found in the upper part of the Bělka bed, but some were at or near its base. Sphenophyllum pseudoaquense was also a true liana, as it had hooked trichomes on its axes, climber hooks on its leaves, and was found unequivocally wrapped around the fallen trunk and "crown" branches of a "L." simile tree. This species covered $13 \%$ of the excavation surface, but encircled a tree that was originally growing outside of the excavation area. The three lyginopterid pteridosperms covered $25 \%$ of the excavated area, but if $S$. pseudoaquense is included, the amount of cover would increase to $32 \%$ (Figs. 19, 20). In reality, the lianescent plants were part of the upper and lower canopy, where they presumably occupied gaps that had full access to sunlight, although not all of these spaces were necessarily filled (Fig. 23).

\subsubsection{Ground cover and/or climbers}

The remains of all of the species included in this category covered $28 \%$ of the excavated area, within which they had a very patchy distribution (Figs. 19, 20). The only true ground cover species was Sphenophyllum cf. majus (Fig. 19), which covered $13.0 \%$ of the excavation surface (Table 2 ) and was most common in areas where erect stems were absent. There were no structural indicators (e.g., climber hooks, spines) that this species was able to cling to or climb arborescent vegetation, in contrast to Sphenophyllum pseudoaquense mentioned above.

Within this category we also include species that crept along the forest floor as part of the ground cover until they reached vegetation that provided suitable support for their climbing habit. In comparison with the true lianas described above, the remains of these species were more commonly uncovered in parts of the excavation where erect stems were not present, and thus we consider them part of the ground cover. This is in agreement with the observation that their remains usually occurred in the basal few centimeters of the Bělka bed, although in proximity to upright stems they were often found at all levels of the tuff bed and even reached into the overlying Brousek unit. The zygopterid ferns Corynepteris angustissima (percentage 
cover $10.6 \%$ ) and Desmopteris longifolia (0.4\%) had a similar distribution pattern as Sphenophyllum cf. majus, but one example of the former was found coiled around an erect "Lepidodendron" simile stump up to a level $750 \mathrm{~mm}$ above the top of the coal seam (Plate VIII, Figs. 1, 2). This indicates that $C$. angustissima was able to climb vegetation when the opportunity arose, and such a habit was facilitated by its thorny phyllophore with indeterminate growth. The remaining ferns Sphenopteris mixta (2.4\%), Sphenopteris sp. (3.2\%) and Hymenotheca sp. (0.4\%) were comparatively rare in the excavated area, and little is known of their life strategies or growth habits. However, they could represent either climbers or ground cover elements, and hence we include them in this category. Similarly, the herbaceous bisporangiate lycopsid (1.2\%) may also represent a climbing plant, although it could have been an epiphyte since all of its remains were only found in the upper part of the Bělka bed and the lower part of the Brousek unit in association with a Cordaites borassifolius stem.

\subsection{Sexual maturity and timing of reproduction}

Burial of the Lower Radnice peat-forming forest in a geological instant has presented a superb opportunity to establish which plants reached sexual maturity concurrently, or at least were simultaneously in a reproductive phase of their life cycle (Table 2). Of the arborescent lycopsids, remains of the species "Lepidodendron" (= Paralycopodites) simile and Lepidophloios cf. acerosus included abundant cones. The former was presumably polycarpic like other members of Paralycopodites, and thus repeatedly produced cones from lateral branches. In contrast, $L$. cf. acerosus was probably a monocarpic form that only branched and produced a massive number of cones in the terminal, reproductive phase of its life cycle. No fructifications of Lepidodendron lycopodioides were found, although if it too belonged to a monocarpic genus, the presence of leafy shoots and narrow, leafy branches of this species indicates that it too may have been reproducing. Similarly, the slow-growing Cordaites borassifolius tree, which undoubtedly reproduced several times throughout its extended life, was represented by numerous cones and seeds. Thus, it seems that the majority of the tree storey species were in a reproductive phase when the ash fell (at least 3 but possibly 4 of 5 species, or 60 to 80\%). In the understorey, only Stylocalamites sp. was represented by rare Palaeostachya cones ( 1 of 4 , or $25 \%$ ). Similarly, of the plants that had a true lianescent habit, only Sphenophyllum pseudoaquense was fertile (1 of 4, or $25 \%$ ). However, almost half ( 3 of 7 , or $43 \%$ ) of the species interpreted as ground cover/ climber elements included fructifications among their remains (i.e., Sphenophyllum cf. majus, Corynepteris angustissima, herbaceous bisporangiate lycopsid). On the whole, at least 8 biological species (and possibly 9 if L. lycopodioides is included, or 40 to $45 \%$ of all taxa) were in a reproductive phase at the time of the eruption. This is a surprisingly large percentage, given the large variation in reproductive strategies of the plants in the Lower Radnice peat-forming forest.

A plant obviously needs to be fully-grown before it can reproduce, and thus we can confidently conclude that a minimum of 40 to $45 \%$ of all

Plate VI.

Fig. 1. Prostrate lepidodendrid stem associated with Sphenophyllum pseudoaquense. Remains of this species completely encircled the lycopsid stem.

Fig. 2. Detail of Sphenophyllum pseudoaquense from Fig. 1.

Fig. 3. Detail of a central axis of Sphenophyllum pseudoaquense. Note the differences in leaf sizes on central and distal axes. A small cone is attached to the leafy axis.

Fig. $4 . \quad$ Detail of Sphenophyllum pseudoaquense.

Fig. 5-7. Details of climber hooks terminating leaves.

Plate VII. (see on page 262)

Fig. 1. Pecopteris aspidioides. Fragment of a pinna.

Fig. 2. Corynepteris angustissima frond and phyllophore fragments with trichomes.

Fig. 2a. Detail of Fig. 1. $2 \times$.

Fig. 3. Desmopteris longifolia frond fragment.

Fig. 4-5. Hymenotheca sp. Small fragments of a pinna.

Fig. 5a. Detail of Fig. 5. $2.5 \times$.

Fig. 6. Sphenopteris sp. Small fragment of a pinna.

Fig. 7. Aerial roots of the medullosan stem in unit A1 (S1).

Fig. 8. $\quad$ Fragment of frond of Laveineopteris loshii.

Plate VIII. (see on page 263)

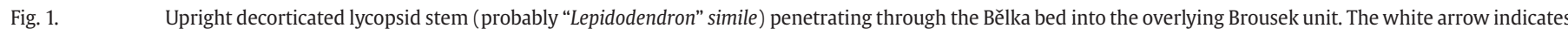
the boundary between the Bělka and the Brousek. The black arrow points to Corynepteris angustissima phyllophores surrounding the stem.

Fig. 2. Detail of Corynepteris angustissima axes and the lycopsid stem from Fig. 1.

Fig. 3. Corynepteris angustissima remains associated with a calamitean stem (cal).

Plate IX. (see on page 264)

Fig. 1. Small fragment of Palmatopteris furcata.

Fig. $2 . \quad$ Sphenopteris mixta.

Fig. 3-4. $\quad$ Frond fragments of Mariopteris muricata.

Fig. 5. Large frond fragments of Eusphenopteris nummularia in upper part of the Bělka bed. Unit 1C4 (S2).

Fig. 6-7. Details of the Eusphenopteris nummularia fronds from Fig. 5.

Plate X. (see on page 265)

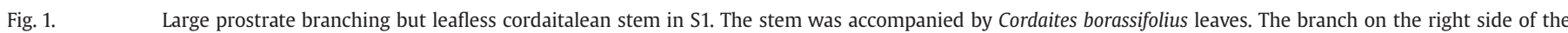
excavation continued up to the cordaitalean stem, and was in fact the apical part of the stem.

Fig. 2. Cordaites borassifolius branch with attached leaves in S2.

Fig. 3. Artisia pith cast of a cordaitalean branch.

Fig. $4 . \quad$ Cardiocarpus sp., a cordaitalean seed. 


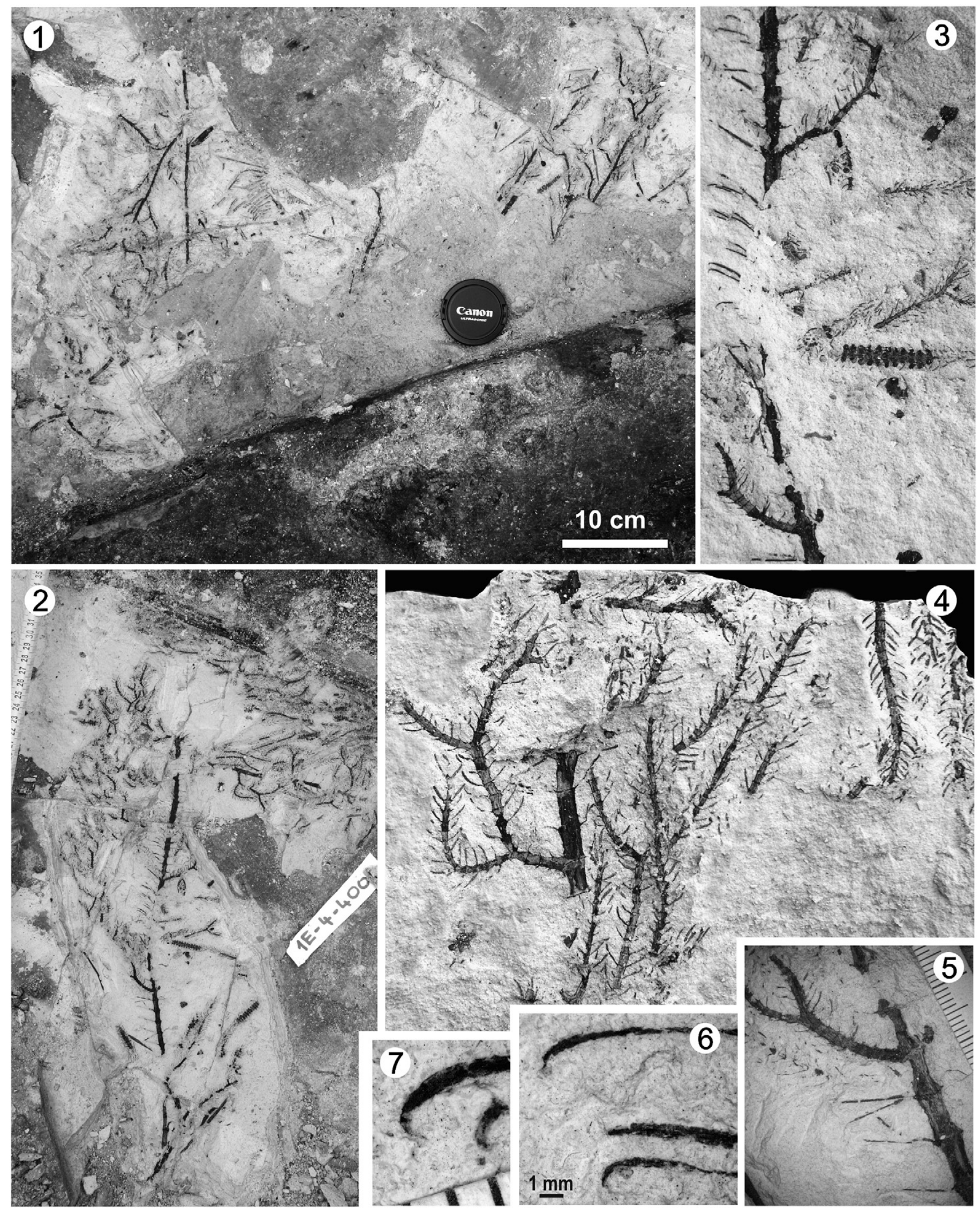




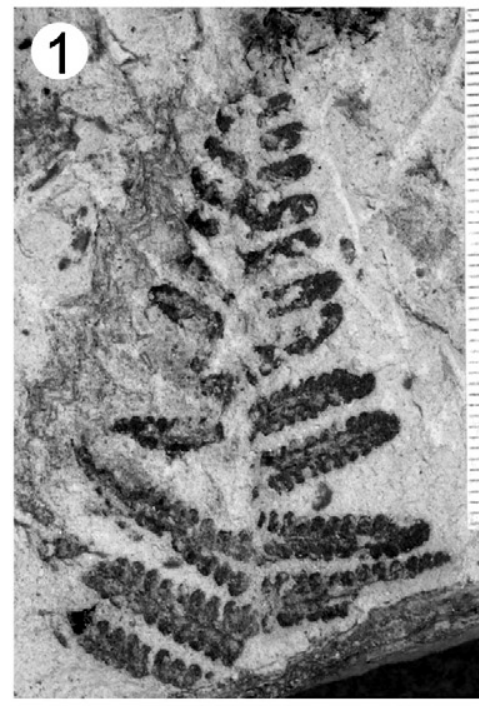

$3-6,5.5$
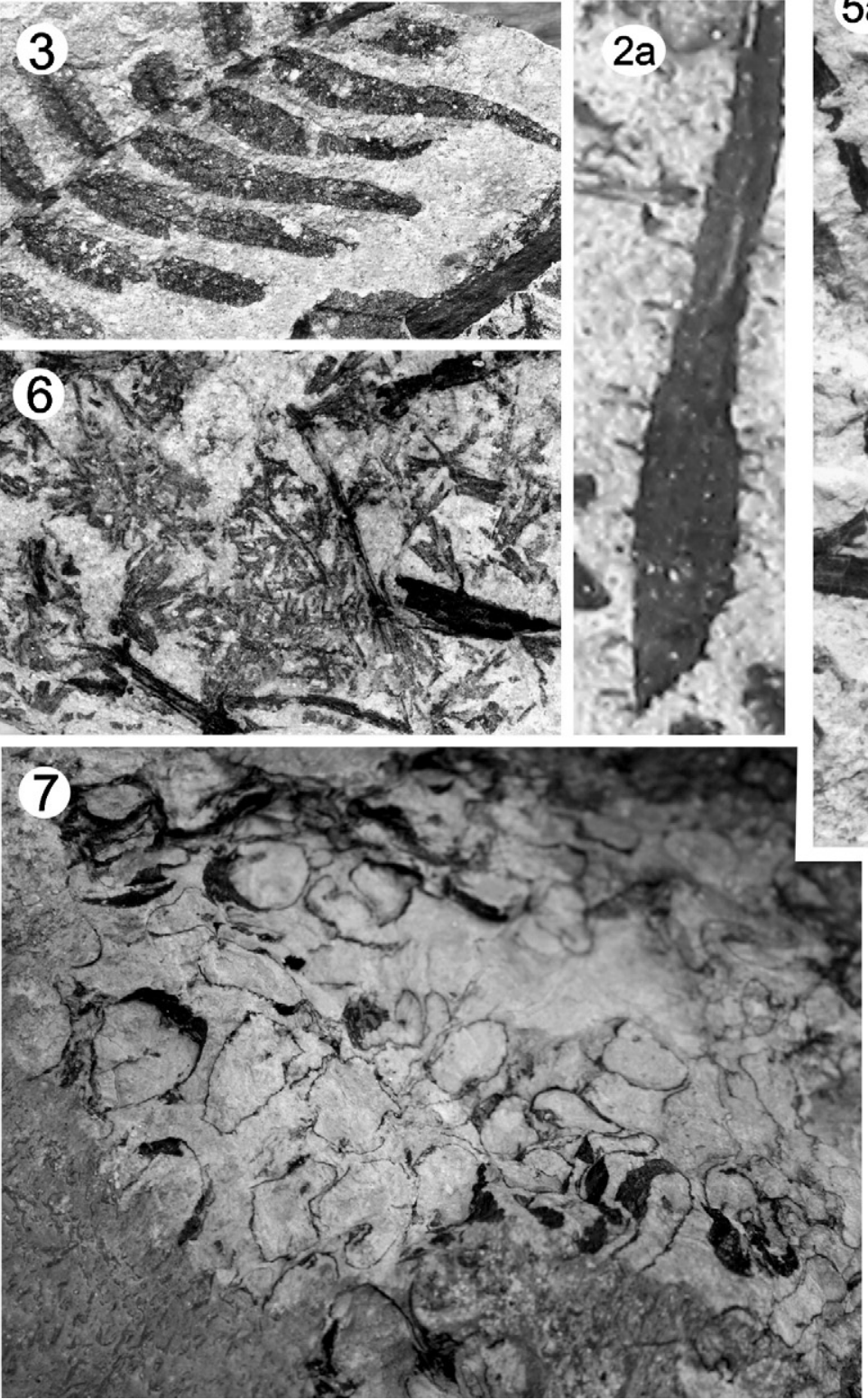

2<smiles>c1ccccc1</smiles>

s. एकी

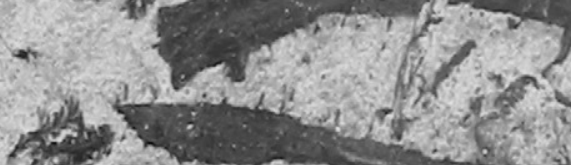

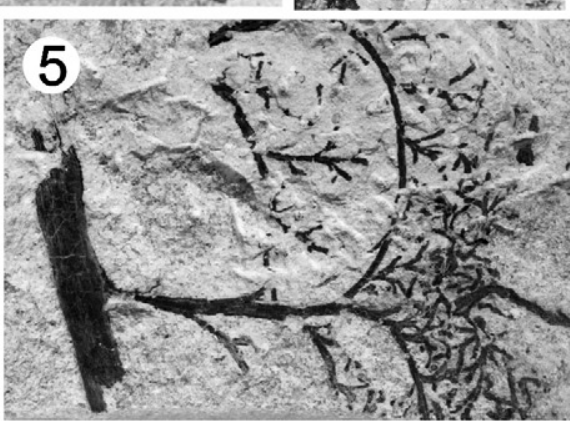
1) of
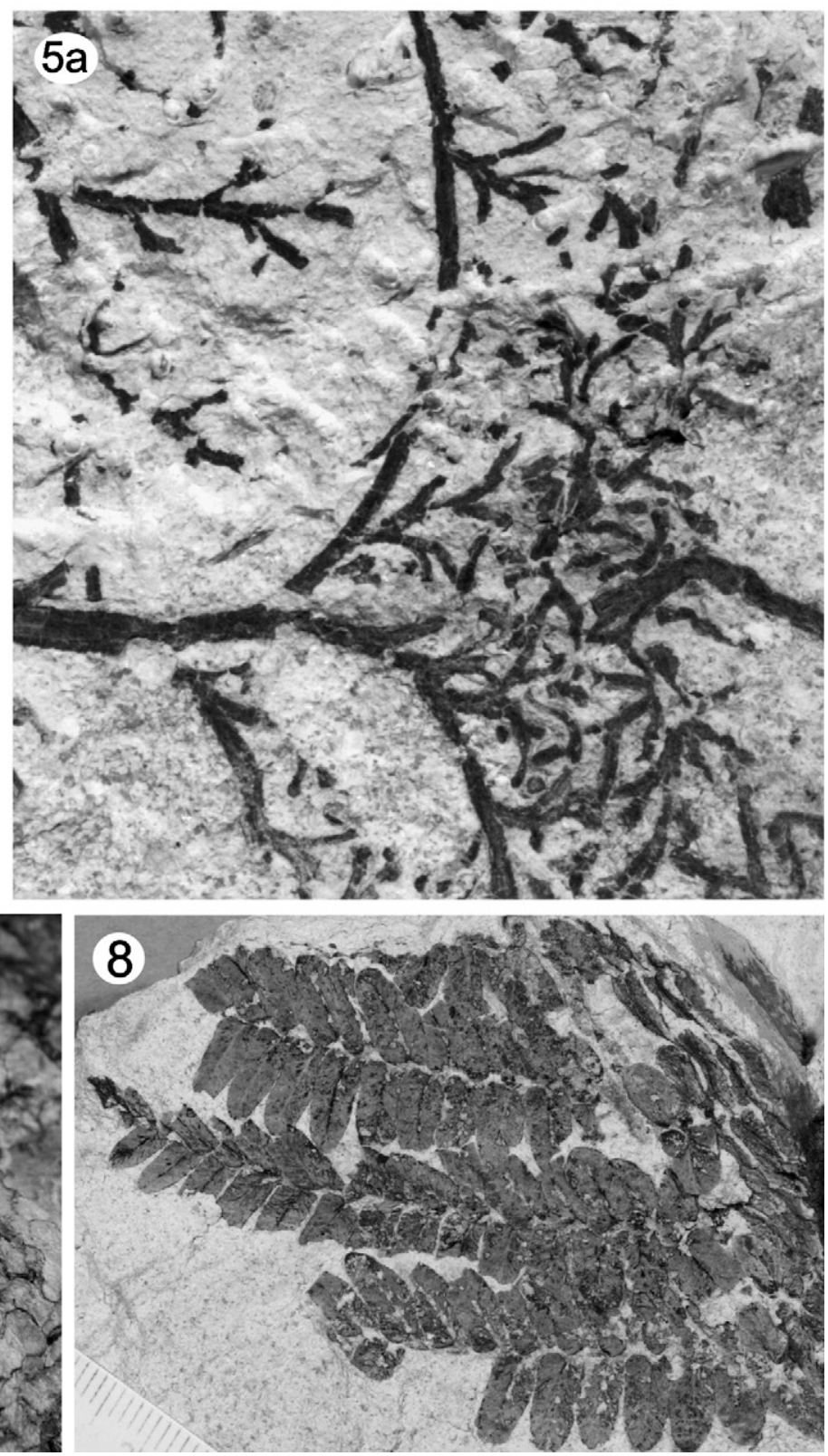


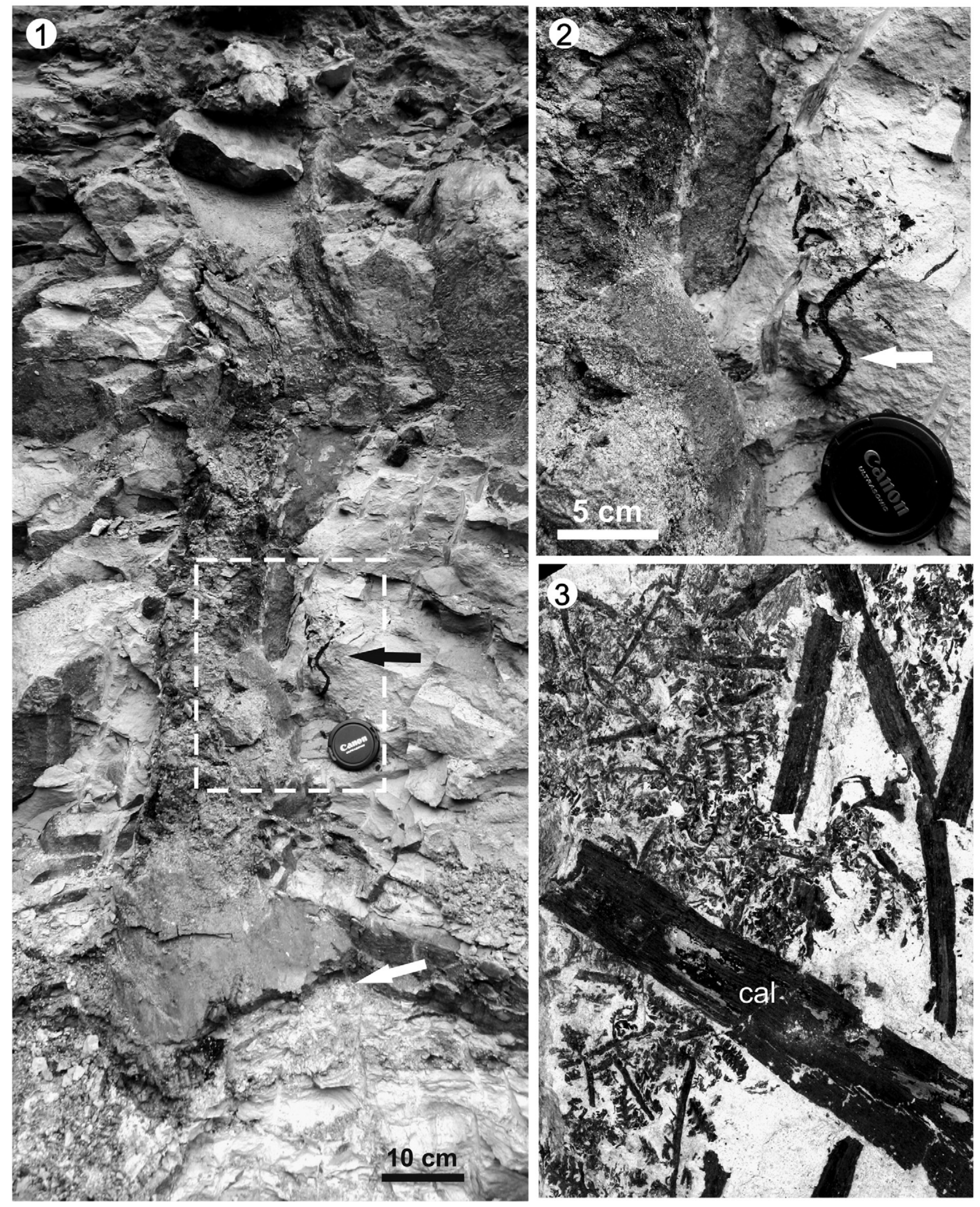



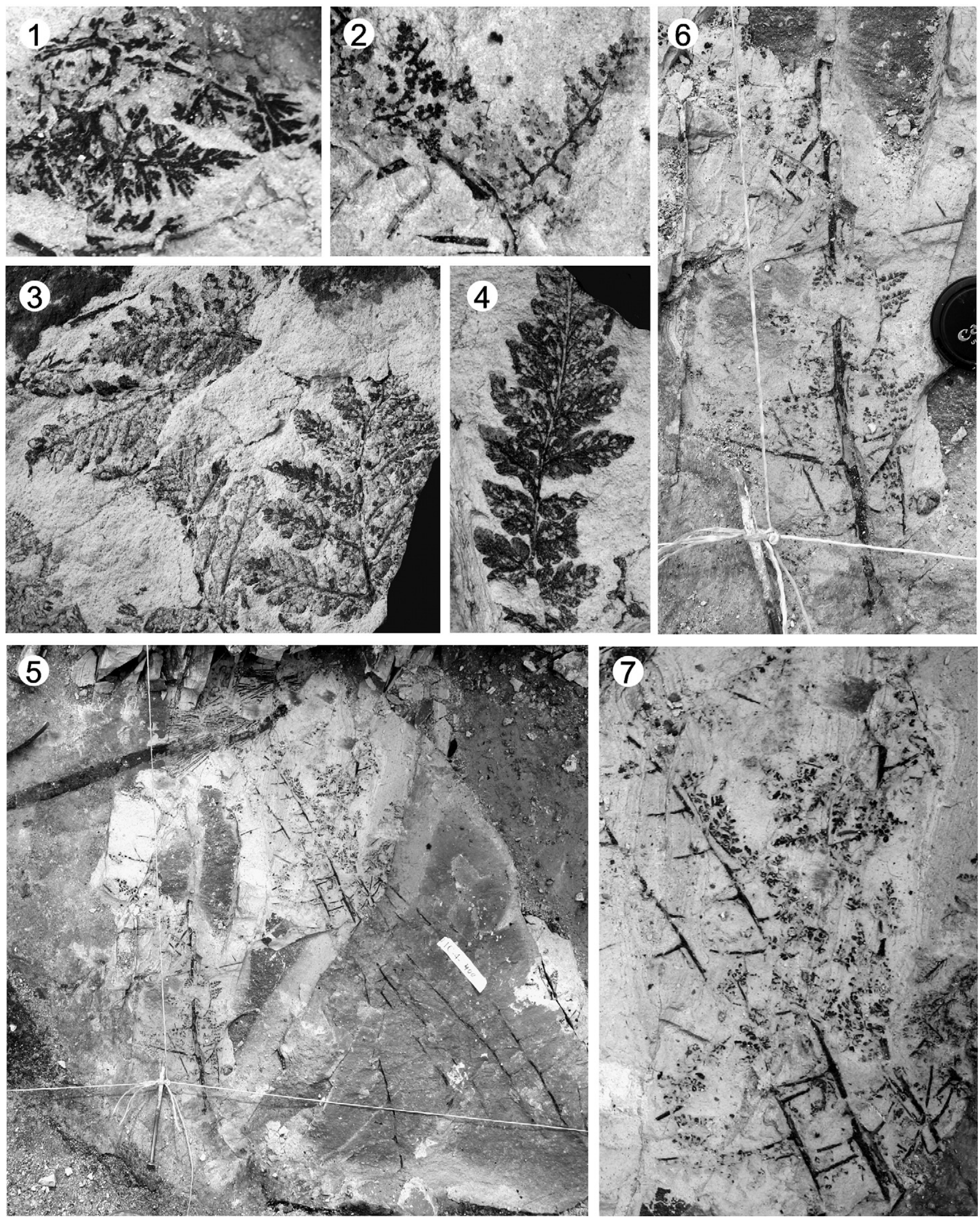

Plate IX (caption on page 260). 


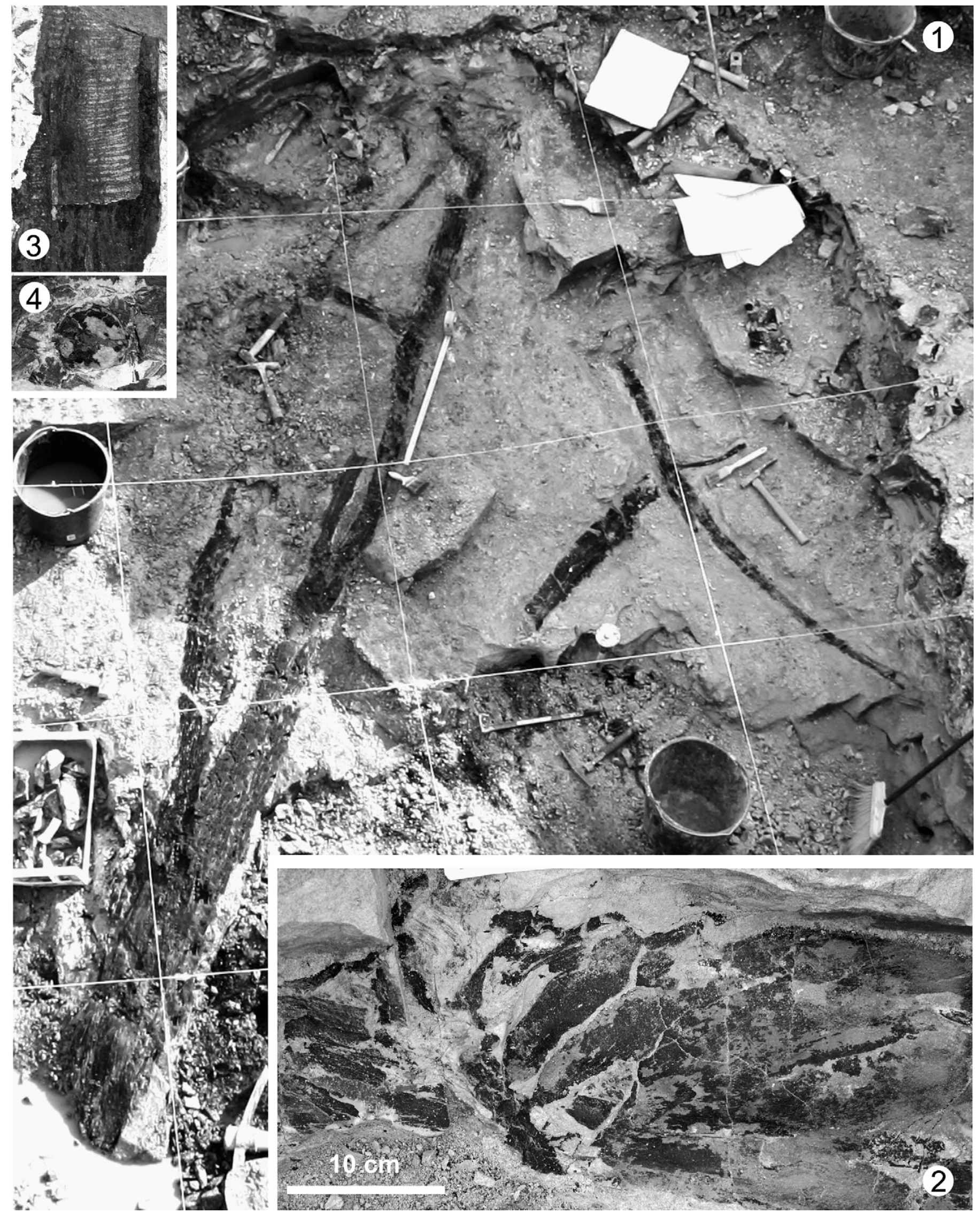




\section{Growth Forms}

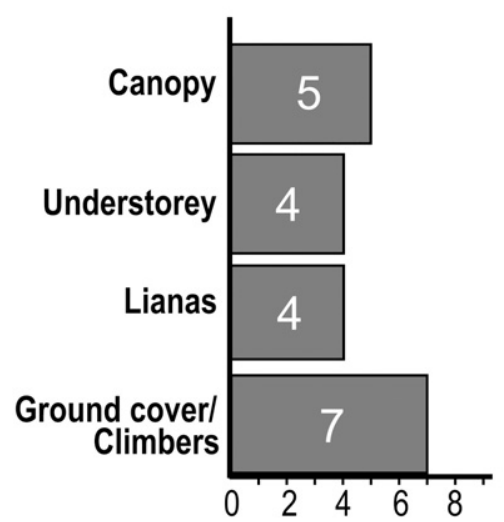

Taxonomical composition

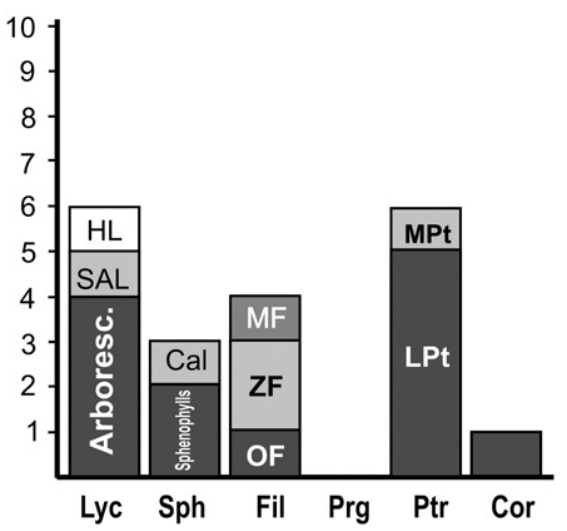

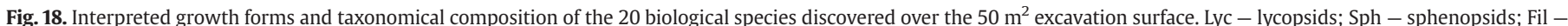

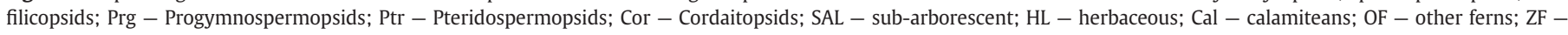
zygopterid ferns; MF - marattialean ferns; LPt - lyginopterid pteridosperms; MPt - medullosan pteridosperms.

taxa present in the excavation was sexually mature at the time of the eruption (i.e., not every mature plant necessarily bore fructifications). The only specimen that shows unequivocal characteristics of a juvenile is the pole-like Lepidodendron longifolium tree, and hence it is probable that the majority of plants in the community had reached maturity when the ash fell. Although the fact that so many species were reproducing at the time of burial may simply reflect the fact that most were mature (W.A. DiMichele, pers. comm., Nov. 2008), it is also tempting to look to either intrinsic or extrinsic controls to explain the fecundity of the mire vegetation. We believe that two mechanisms, on different time scales, are required to explain our observations: one to substantiate the overwhelming proportion of sexually mature plants, and another to account for the synchronisation of reproduction.

The simultaneous attainment of sexual maturity for much of the vegetation suggests contemporaneous establishment in the mire following widespread disturbance. Peat formation may have been temporarily halted by a major flood event that killed most of the vegetation, with recolonisation of open, clastic and/or peat substrates occurring subsequent to shallowing (i.e., a Class-II disturbance (sensu White and Pickett, 1985) that initiated secondary succession). This scenario is likely given the large number of clastic partings in the upper parts of the Lower Radnice Coal, each of which resulted from increasingly frequent incursions of sediment-laden floodwaters. Interestingly, Libertín et al. (2009-this volume) documented a plant fossil assemblage above the Lower Radnice Coal in the former opencast Štilec Mine (20 km east of the excavation studied herein) that was buried by the very same volcanic ash fall (i.e., it is a $T^{0}$ deposit at an identical stratigraphic level). The low diversity phytocoenosis was dominated by herbaceous ferns and calamiteans with lesser lycopsids, all of which were of small stature but fertile, and was interpreted as a pioneering community that colonised shallowing, ponded waters above a previously drowned peat-forming mire. Together these observations indicate that the forests forming the Lower Radnice Coal were disturbance dominated, but that disruptions to peat accumulation were spatially random rather than basin-wide phenomena. In the former opencast Štilec Mine, an assemblage is preserved that records initial stages of secondary succession after localised drowning (Libertín et al., 2009-this volume), whereas a more advanced seral community is documented in this study.

It has been demonstrated in modern ecological studies that plant communities subjected to sudden or prolonged stressful conditions can respond by simultaneous reproduction or masting. For example, it has been hypothesised that high predation pressure in a plant population could lead to synchronous or mast fruiting, with the superabundant availability of seeds for a short time achieving predator satiation (Janzen, 1969, 1971). However, there is no obvious evidence of plant predation in the Sternberg excavations. We instead speculate that a minor flood could have placed enough stress on the peat-forming community to trigger the simultaneity of reproduction observed. This minor flood would have occurred not long before the ash fell, and although it had enough intensity to provide the requisite perturbation, it was not severe enough to kill the vegetation. Such a disturbance may also have temporarily increased the resources of the site, as flooding would have brought in nutrients and organic matter from other parts of the landscape (Jentsch, 2004).

Another possible extrinsic control on the timing of reproduction may have been seasonality, which in a palaeotropical setting would have been related to alternating wet/dry cycles of varying lengths. It certainly is plausible that the eruption happened to occur during a season in which most plants were productive, although this explanation is less likely because different taxa in mixed forests tend to reproduce at different times of the year dependent on prevailing physical factors (e.g., a change in edaphic conditions, light intensity or duration, or nutrient supply) (Whitmore, 2006).

\subsection{Estimation of the minimal area}

According to Mueller-Dombois and Ellenberg (1974), the minimum area required to characterise modern forest phytocoenoses varies between 200 and $500 \mathrm{~m}^{2}$. This so-called minimal area is considered the minimum area necessary to obtain statistically meaningful data about the composition and taxonomic diversity of any forest ecosystem. To determine the minimal area, a graph indicating the relationship between the number of new species present ( $Y$-axis) in a gradually increasing area ( $X$-axis) is constructed (Cain, 1938; Moravec et al., 1994). The resulting plot is usually very steep at the beginning of the survey when the area is small and the increment of new species is high, but ultimately becomes subhorizontal when the increment of new species decreases with increasing area. The minimal area is revealed when the curve becomes constantly sub-horizontal to horizontal, meaning that few if any new species are encountered over an ever-expanding search area. In effect, this is a rarefaction curve.

We realize that the $50 \mathrm{~m}^{2}$ area exposed in the excavation is probably too small to establish the minimal area and true diversity of vegetation that comprised the peat-forming forest of the Lower Radnice mire. Nonetheless, a curve was plotted to see if any information was revealed. A rectangular-shaped area proportional to the outline of the excavation was gradually enlarged from an initial 


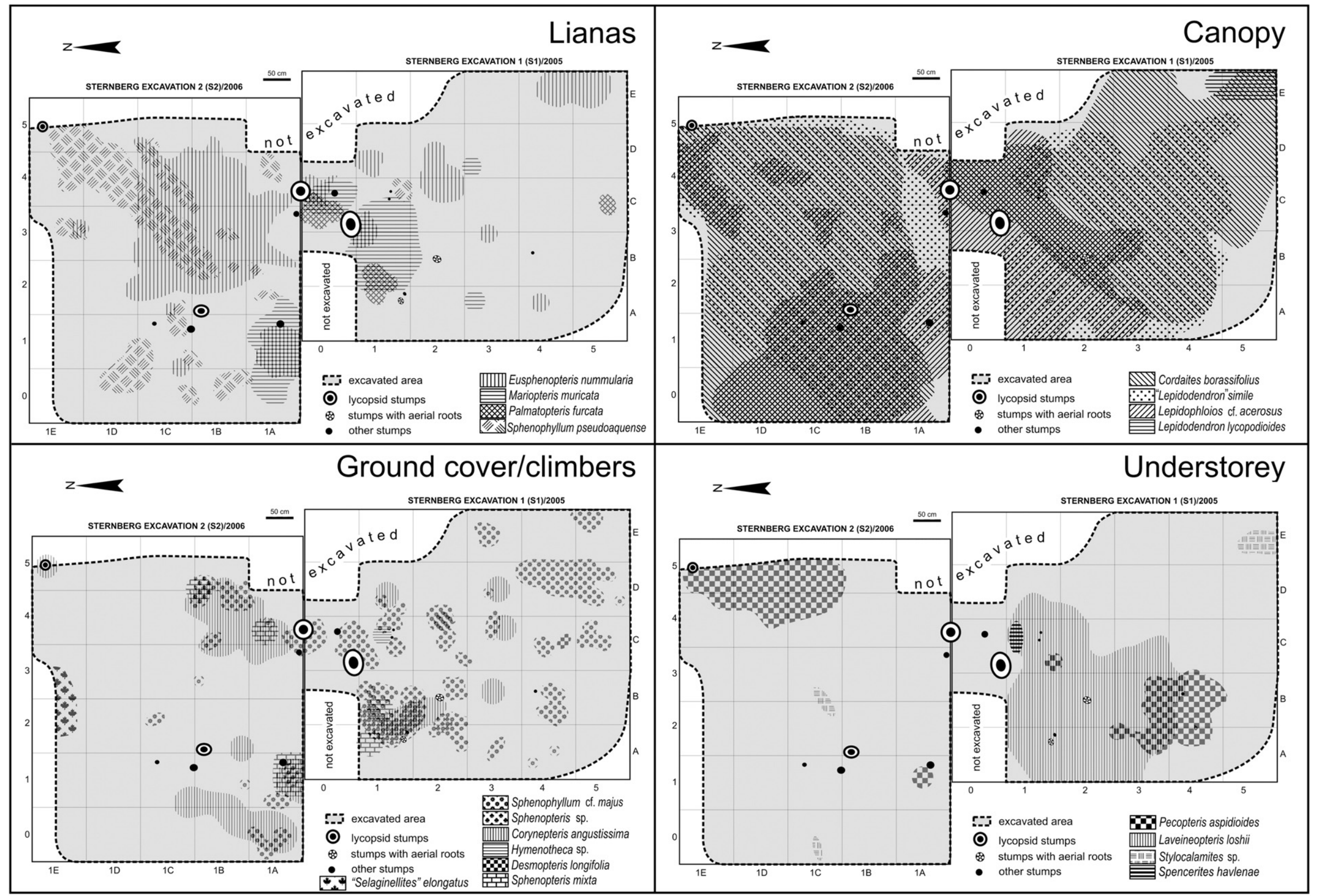

Cover of particular storeys 


\section{Growth Forms}

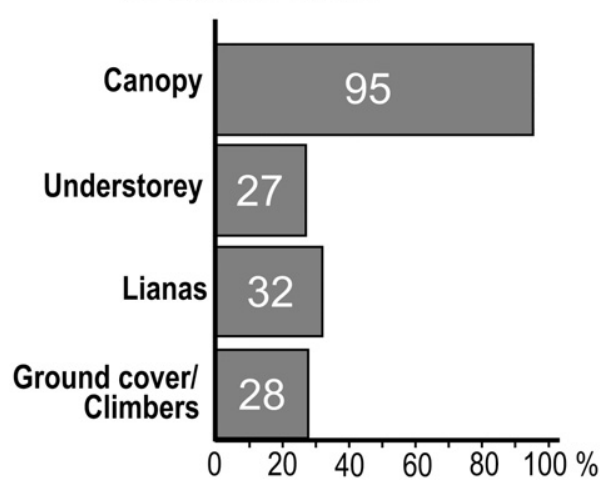

Fig. 20. Combined percentage cover of forest storeys within the excavated area.

size of $0.5 \mathrm{~m}^{2}$ up to $50 \mathrm{~m}^{2}$, starting in the northwest corner of $\mathrm{S} 2$. The number of new species present was recorded in the following successively larger increments of area $\left(\mathrm{m}^{2}\right): 0.5,1,2,4,8,16,24,32$, 40 and 50. Unexcavated parts were excluded from the test. The resulting curve (Fig. 22) rises quickly up to an area of $24 \mathrm{~m}^{2}$, with the number of new species encountered ranging between 1 and 6 in each step. Thereafter, the curve begins to flatten out, with only 1 new species occurring at each increment despite the larger sampling area. This flattening resembles what is normally found in a modern forest phytocoenosis, but because further enlargement of the excavation area is no longer possible, it can not be proven if the drop in diversity represents a local decline in species richness or remains stable and thus approaches the true minimal area. Despite this uncertainty, the curve is similar to that constructed for another excavation of the Bělka bed, which was located about $200 \mathrm{~m}$ away and preserved a peatforming forest taphocoenosis comprising 24 biological species in almost double the area $\left(93.5 \mathrm{~m}^{2}\right.$ ) (unpublished data). In addition, based on the rich plant fossil collection in the National Museum, Prague, only about 30 whole-plant taxa are known from the Bělka bed in the adjacent opencast Ovčín Mine, despite several years of collecting and exposures covering approximately $120,000 \mathrm{~m}^{2}$. It should be noted that three species discovered in the yet unpublished excavation have never been found in the opencast mine, bringing the number of biological species in the local area to 33. Therefore, the relatively small discrepancies between the species richness values obtained in the present excavation $(S=20)$, the nearby excavation soon to be documented $(S=24)$, and the adjacent opencast Ovčín Mine combined with the nearby excavation $(S=33)$, despite vastly different areas of exposure (50, 93.5 and $120,000 \mathrm{~m}^{2}$, respectively), indicates that even small areas of excavation can reveal a significant diversity of species. This clearly illustrates the fact that the Lower Radnice mire vegetation was compositionally homogeneous, with the same species essentially spread throughout the entire swamp. In contrast, the data indicate that these plants had an exceptionally heterogeneous distribution, with patchiness occurring at a very fine scale.

\section{Comparison with other in situ peat-forming forests}

There are few known examples of upper Palaeozoic peat-forming ecosystems being buried and preserved in situ by volcanic ash. Localities have previously been recorded from the Intra Sudetic Basin (Czech Republic), Puertollano Basin (Spain), Döhlen Basin (Germany) and Wuda Basin (China). Although each of these sites have yielded important information on the composition of upper Carboniferous and lower Permian mires, the methods of data collection do not yet allow for the reconstruction of the spatial distribution of individual peat-forming plants with the fidelity we have documented herein. As a consequence, these occurrences offer little for accurate comparison with our excavation. Instead, descriptions of in situ Westphalian assemblages preserved in coal balls and in roof-shales above rapidly drowned mires ( $T^{0}$ deposits) offer the best prospects for comparison.

\subsection{Comparison with coal ball floras}

Over 65 coal seams containing coal balls are known from North American, European and Chinese coalfields, ranging in age from the early Namurian to the Stephanian (Phillips, 1980; Tian et al., 1996). Standardised qualitative and quantitative analyses performed on coal balls provide insight into mire diversity, the biomass contribution of particular plant taxa, lateral heterogeneity and successional stages within a single swamp, as well as changes in the composition of peatforming forests throughout the Pennsylvanian (DiMichele and Phillips, 1994, and references therein). However, a complaint of coal balls is that they can contain both time-averaged and taphonomically filtered data (e.g., Behrensmeyer et al., 2000; Gastaldo et al., 2004b). Although this is certainly the case in some circumstances, careful analysis of successive coal balls on a layer-by-layer basis has diminished these biases (Phillips et al., 1977; Phillips and DiMichele, 1981).

The study of coal balls from a variety of localities and ages indicates that Westphalian peats were dominated by arborescent lycopsids, which contributed 75 to $84 \%$ of peat biomass in the Langsettian, 44 to $74 \%$ in the Duckmantian and Bolsovian, and 55 to $75 \%$ in the Asturian, with a significant decrease to about $10 \%$ of peat volume in lower Stephanian examples (Phillips, 1981; Phillips and Peppers, 1984; Phillips et al., 1985). Furthermore, cordaitaleans reached their zenith in Euramerican peat swamps during the Bolsovian, at which time they contributed between 10 and $15 \%$ of peat biomass. The sphenopsids, ferns and pteridosperms produced the remaining 15 to $20 \%$ of peat volume in the Bolsovian. Although our small area of excavation clearly does not provide a reliable representation of biomass contribution for the entire Lower Radnice mire, the percentage cover values we calculated offer a rough guide to its composition. Within the excavated area, the lycopsids were the primary contributors to biomass (39.0\%), followed by the cordaitaleans (26.7\%), pteridosperms (17.1\%), ferns (7.3\%), and sphenopsids (9.5\%) (Table 2). Thus, although lycopsids were dominant, they may have been somewhat less important in this peat-forming community than in others of a similar age, whereas the cordaitaleans were more abundant. Similarly, the pteridosperms, ferns and sphenopsids (combined 33.9\%) that comprised the majority of the understorey, ground cover and liana habits appear to have been richer than was typical of most Bolsovian mires. Of course, we are cognizant of the fact that percentage cover may not actually provide a useful proxy for estimating biomass contribution. For example, a lycopsid branch covering $1 \mathrm{~m}^{2}$ of the excavation surface surely contributed vastly more biomass to peat than a pteridosperm frond of the same dimensions. Hence, although the pteridosperms, ferns and sphenopsids were represented by 13 biological species (i.e., $65 \%$ of all taxa), their actual contribution to peat biomass would have been rather small given their physiology and small stature growth habits.

The amount of taxonomic diversity found in Westphalian coal balls varies widely, although this disparity may be partly influenced by the intensity of study of a particular coal seam. The richest European coal ball assemblages are of Langsettian age, with the Upper Foot and Union coals in the Lancashire coalfield, U.K. and Bouxharmont Coal in Belgium comprising 72, 71 and 54 species, respectively (Galtier, 1997). However, these richness values include counts of all form-taxa, and do not accurately reflect the diversity of whole-plant species. Our estimation of true biological species diversity for the same coals is ca. 44, 43 and 40, respectively. These approximations are thus more in line with species richness values obtained from Asturian coal balls in American coalfields, which were typically colonised by 40 to 50 biological species (DiMichele and Phillips, 1996). Although Winston (1988) found only 33 whole-plant taxa in the Asturian Herrin Coal in 


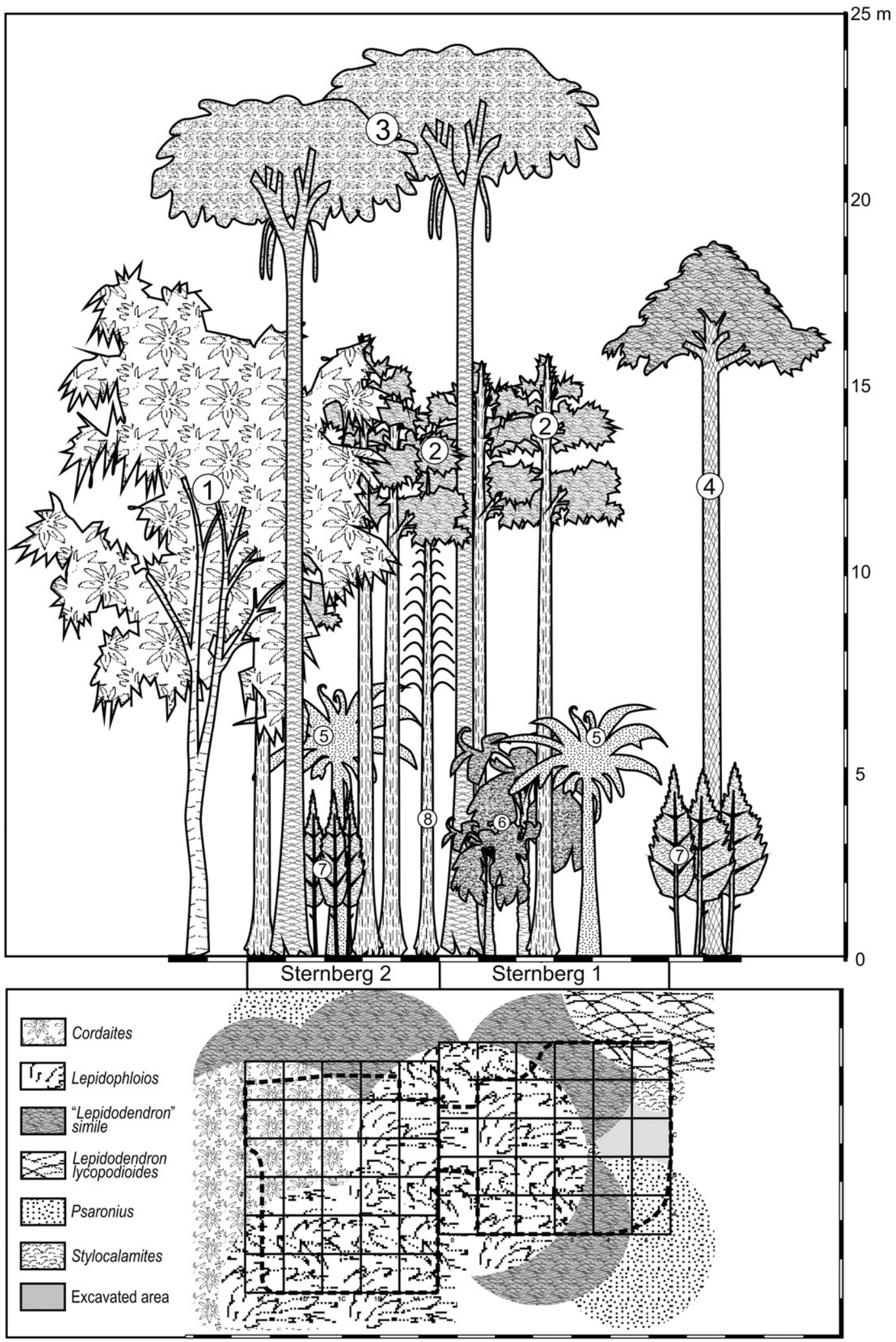

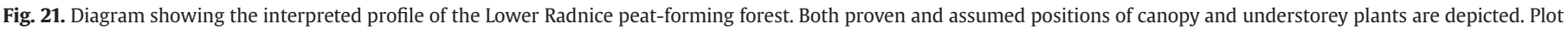

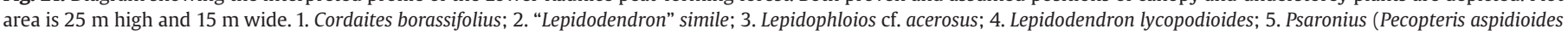

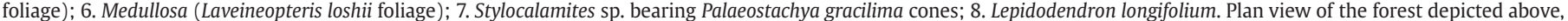
illustrating possible lateral extent of overlapping canopies of various plants.

the Illinois Basin, and DiMichele et al. (2002) similarly reported between 16 and 30 biological species from four Asturian coals in the same basin, both studies focused on local sites within much larger mires. Finally, a very low diversity assemblage dominated by lycopsids was recorded from late Bolsovian coal balls in the Stellarton Basin of Nova Scotia, where only eight whole-plant taxa were found (Lyons 
et al., 1997). However, the paucity of taxa in these coal balls is undoubtedly a manifestation of their very poor state of preservation (W.A. DiMichele, pers. comm., Nov. 2008).

Most of these coal ball assemblages yielded a significantly higher richness than the 20 whole-plant species found in the Sternberg excavations. However, it is necessary to appreciate that only $50 \mathrm{~m}^{2}$ of area was excavated. Furthermore, species richness values from most of these previously documented coal ball assemblages represent combined data from a large sample of coal balls taken from numerous collection sites, and therefore the spatial heterogeneity of a single mire has been homogenised. Finally, these samples may have included plant communities from more than one generation of mire development, thus artificially escalating the recorded diversity values. As a consequence, the 20 biological species recorded herein, combined with the fact that 33 species have been documented from the Bělka bed in the adjacent opencast Ovčín Mine and neighbouring excavations, suggest that the species richness in the Lower Radnice Coal was comparable to some of the less diverse Westphalian mires in the U.S.A.

DiMichele and Phillips (1996) distinguished three major plant communities in upper Carboniferous mires: (i) assemblages dominated by the monocarpic, arborescent lycopsid Lepidophloios hallii; (ii) assemblages dominated by the polycarpic, arboresent lycopsids Diaphorodendron scleroticum and/or Sigillaria sp.; and (iii) assemblages dominated by medullosan pteridosperms and the polycarpic, arborescent lycopsid Paralycopodites brevifolius. The Lepidophloiosdominated assemblage was characterised by low biomass and low diversity in all storeys that, together with the low abundance of ground cover and homosporous ferns, supports the inference that peat substrates were flooded for long periods of time. Assemblages dominated by Diaphorodendron and/or Sigillaria were characterised by abundant ground cover and understorey taxa, although species richness was low. This community was interpreted to have colonised occasionally flooded, wet peat substrates. Finally, the assemblage dominated by medullosan pteridosperms and Paralycopodites typically had high diversity in all storeys, and included plants that preferred high ash peat substrates along the margins of mires that were frequently disturbed by flooding or wildfires (based on a high charcoal content). Of these three generalised plant communities, the Lower Radnice Coal in the Sternberg excavations and adjacent opencast Ovčín Mine fits best in the third grouping. In particular, the upper part of the Lower Radnice Coal contains numerous thin clastic partings and

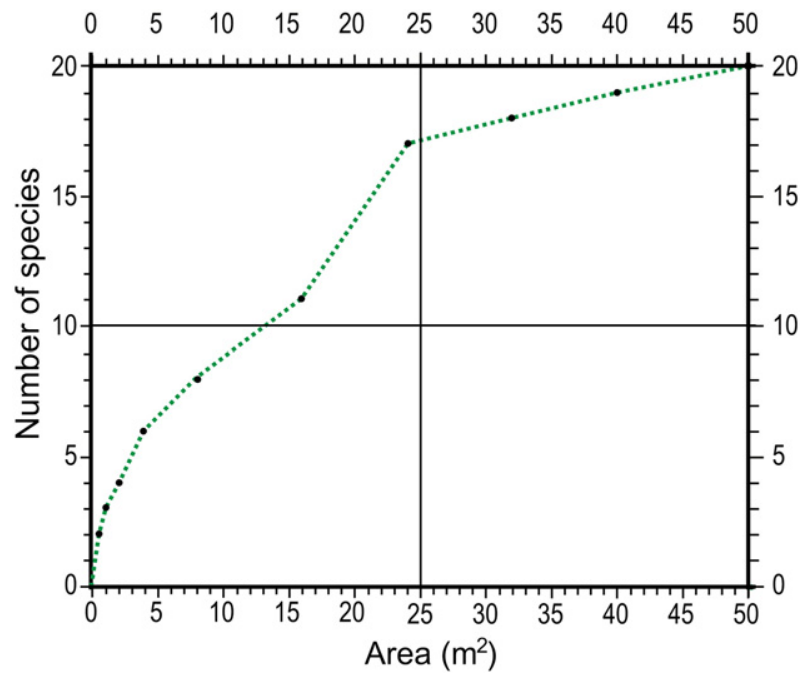

Fig. 22. Incremental increase in the number of new species encountered over an expanding area of the excavation surface, in order to estimate the minimal area. The first sample area was in the northwestern corner of S2, and incrementally expanded towards the southeast. See text for details. charcoal fragments, which indicates that it represents a frequently disturbed, planar (rheotrophic) mire. In addition, "Lepidodendron" (= Paralycopodites) simile trees dominated in the excavations. The abundance of both medullosan (Laveineopteris loshii) and lyginopterid (Palmatopteris furcata, Eusphenopteris nummularia, Mariopteris muricata, and possibly Sphenopteris mixta) pteridosperms in the excavations further supports inclusion in the medullosan pteridosperm/ Paralycopodites-dominated community of DiMichele and Phillips (1996). In fact, there are only two points at which the mire of the Lower Radnice Coal diverges from this third category: (i) the presence of Lepidophloios cf. acerosus is somewhat atypical, although it is consistent with the range of edaphic tolerance documented for this genus (Phillips and DiMichele, 1992; DiMichele and Phillips, 1994); and (ii) cordaitalean remains comprise a significant proportion of the biomass. However, this latter point can be explained by the fact that DiMichele and Phillips (1996) defined their assemblages based on late Asturian mires, at which time cordaitaleans were a minor component of most peat-forming habitats.

\subsection{Comparison with roof-shale floras}

Fossil plant assemblages preserved in a roof-shale directly overlying a coal seam can, in some circumstances, represent the mire vegetation in the final phase of peat accumulation. However, a genetic relationship can only be confidently established under two scenarios. If the swamp was slowly but continuously inundated by fine-grained sediment, erect axes and adpressed plant fossils representing litter on the forest floor may be preserved in autochthonous and parautochthonous accumulations (Type B assemblage of Gastaldo et al., 1995). Even more instructive palaeoecological information on the composition and spatial heterogeneity of peat-forming forests can be gained when the mire was dropped below base level or sea level due to a coseismic event, or due to sudden crevassing of a nearby fluvial channel. This resulted in death of the swamp vegetation, either by rapid drowning or burial by splay sedimentation, with plant remains preserved in original spatial context at their site of growth. Such assemblages are primarily autochthonous, with axes still rooted in the top of the underlying coal seam, ground cover plants cross-cutting bedding planes, and forest floor litter lying where it fell (Type A assemblage of Gastaldo et al., 1995). Several examples of such $T^{0}$ deposits are known in the literature from Carboniferous strata in various Euramerican coalfields, although they have not always been documented as such (e.g., Klusemann and Teichmüller, 1954; Gastaldo, 1986; DiMichele and DeMaris, 1987; DiMichele and Nelson, 1989; Gradziński and Doktor, 1995; DiMichele et al., 1996, 2007; Gastaldo et al., 2004a,b; Falcon-Lang, 2005, 2006; Calder et al., 2006).

Gastaldo et al. (2004b) described a Langsettian fossil forest preserved in the roof-shale of the Blue Creek Coal in the Mary Lee Coal zone of the Black Warrior Basin, Alabama. They established their qualitative-quantitative model on standardised specimen counts in 17 sites scattered over an area of $>500 \mathrm{~m}^{2}$. Each sample site was represented by a $10 \mathrm{~m}^{2}$ bedding surface (a quadrat). Within each quadrat, the 50 to $150 \mathrm{~mm}$ thick fossiliferous roof-shale was split along successive bedding planes, and presence/absence and abundance data for each taxon was recorded. In total, 47 morphotaxa representing 32 whole-plant species were identified, and significant heterogeneity in the composition and structure of the Blue Creek Coal fossil forest was recognised. The forest was dominated by three arborescent lycopsids (Lepidodendron, Lepidophloios and Sigillaria), with tree ferns and seed ferns together with calamiteans and juvenile lycopsids comprising most of the understorey. The forest had better-developed understorey where canopy contribution was least $(<50 \%)$, but the number of understorey species remained approximately equal to other parts of the forest. In rare situations, ground cover and lianas dominated, indicating almost complete coverage of the forest floor by creepers and/or lianas (e.g., Eusphenopteris and Palmatopteris), which 
prevented the growth of ground cover species. In modern forests, such a high proportion of lianas and ground cover is associated with gaps resulting from death or blow-down of canopy trees (Oliver and Larson, 1990). A comparison of the peat-forming forests of the Lower Radnice Coal from both the Sternberg and the adjacent Ovčín excavations with the Blue Creek Coal in Alabama is limited by the size of the exposed area in the former. Nonetheless, the species diversity seems to be very similar. The coexistence of Lepidodendron and Lepidophloios is a common feature of both the Lower Radnice and Blue Creek coals, which indicates that the environmental tolerances of these lycopsid genera are quite wide. Data on the composition and density of understorey and liana species from both mires are also comparable.

\section{Summary of the Lower Radnice mire}

In the Radnice Basin, the Lower Radnice Coal represents a nutrientrich, rheotrophic (planar) mire that developed in a narrow palaeovalley over an extended period of Bolsovian time (Opluštil, 2005a,b). A

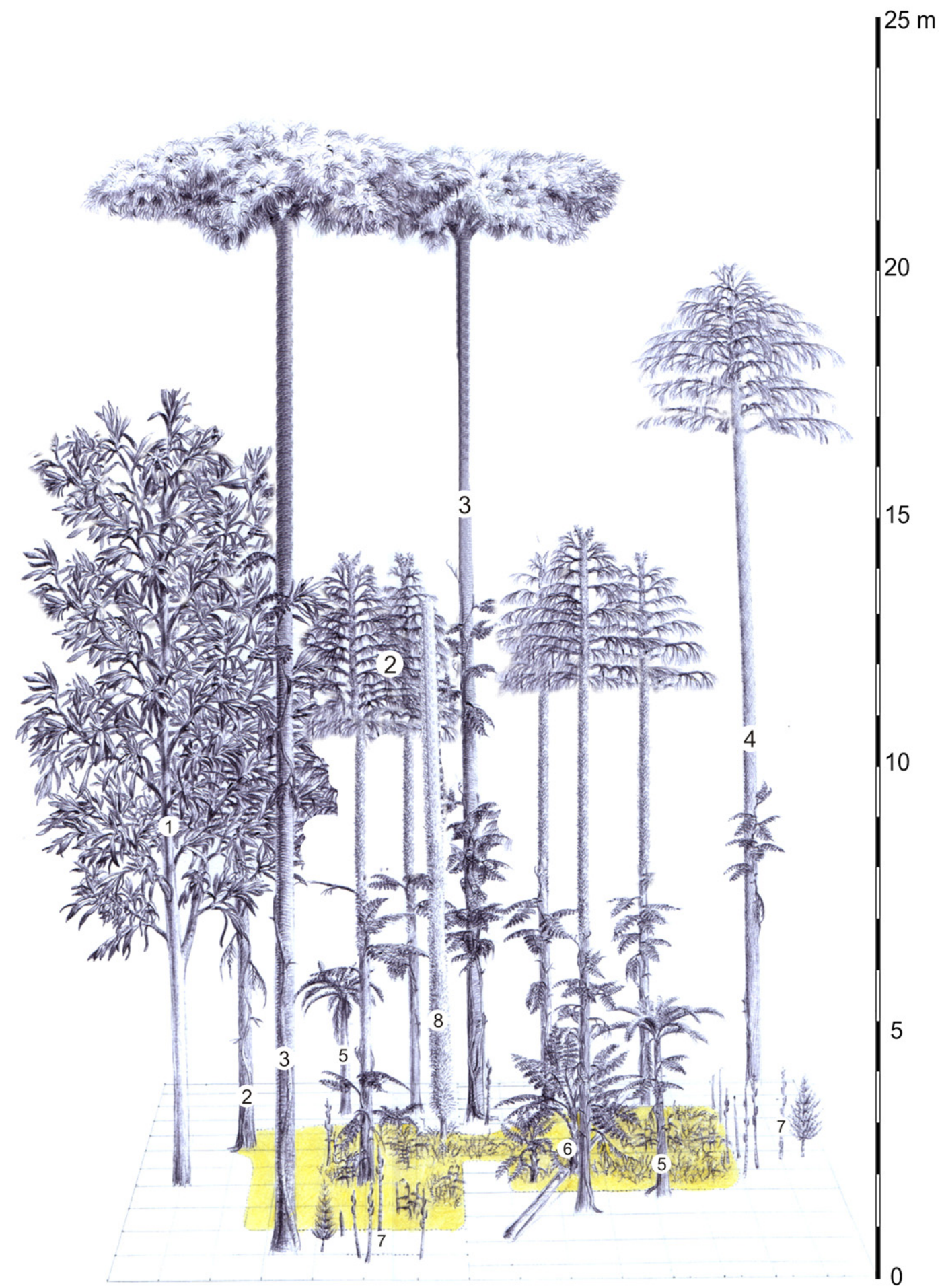

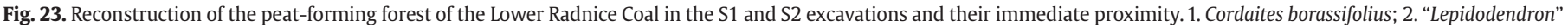

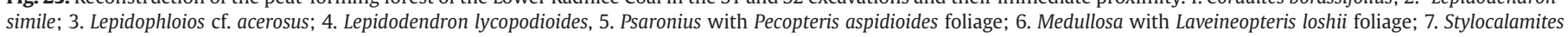
with Palaeostachya gracilima cones; 8. Lepidodendron longifolium. 
contemporaneous fluvial channel located just north of the mire often overtopped its banks, resulting in intermittent but increasingly frequent clastic incursions into the swamp. Peat accumulation was terminated when a large deposit of volcanic ash fell onto and killed the swamp vegetation, effectively burying the plant community in its original spatial context. A $50 \mathrm{~m}^{2}$ excavation of the fossiliferous tuff (the Berlka bed) at the base of the volcanic Whetstone Horizon uncovered the remains of 27 morphotaxa, representing 20 wholeplant species. Surprisingly, this small area contains the bulk of the 33 biological species collected from the Bělka bed over an area of about $140,000 \mathrm{~m}^{2}$ of the Ovčín coal deposit. These data infer that even a localised area of the mire was markedly rich in species with a very patchy distribution, but that the swamp as a whole was compositionally homogeneous.

A variety of growth forms was found in the Sternberg excavations, and the peat-forming forest was divided into an upper and lower canopy of arborescent trees entwined by lianas, an understorey of small-stature plants, and ground cover plants on the forest floor (Figs. 21, 23). The canopy, which was densely distributed but had low species diversity, was dominated by Cordaites borassifolius and "Lepidodendron" (= Paralycopodites) simile, with subdominant Lepidophloios cf. acerosus, and rare Lepidodendron lycopodioides and Lepidodendron longifolium. Each arborescent species probably reached a predictable height when mature, resulting in a vertically heterogeneous canopy in which tree crowns overlapped to some degree. The upper canopy only contained $L$. cf. acerosus trees, which attained heights of $30 \mathrm{~m}$, and the distribution and moderate abundance of this species points to a discontinuous ceiling separated by large gaps. In contrast, the lower canopy was probably denser and more continuous because all other arborescent species seemingly reached similar heights (15 to $20 \mathrm{~m}$ ). However, the pole-like lycopsids would have intercepted little sunlight throughout their life cycles, thus providing adequate space for the wide, densely vegetated crown of $C$. borassifolius. Lianas that occupied canopy gaps were represented by the lyginopterid pteridosperms Eusphenopteris nummularia, Mariopteris muricata and Palmatopteris furcata, all three of which may have simultaneously climbed a single $L$. cf. acerosus tree. Similarly, the sphenopsid Sphenophyllum pseudoaquense was unequivocally found coiled around the upright axes and branches of a "L." simile tree.

In comparison with the canopy, understorey and ground cover species had a more limited abundance and a patchier distribution, which was presumably a consequence of the relatively dense and continuous lower canopy of the forest. Cordaites borassifolius crowns undoubtedly produced the deepest shade in the forest, and hence is it probably not a coincidence that understorey and ground cover species were markedly less dense beneath these trees. The understorey was dominated by the medullosan pteridosperm Laveineopteris loshii and marattialean tree fern Pecopteris aspidioides, with very rare Spencerites havlenae lycopsids and Stylocalamites. Laveineopteris loshii and P. aspidioides primarily grew as isolated individuals, whereas Stylocalamites was grouped into small stands. Ground cover was dominated by the sphenopsid Sphenophyllum cf. majus and the zygopterid fern Corynepteris angustissima, accompanied by scattered Desmopteris longifolia (also a zygopterid fern), Sphenopteris sp. and Sphenopteris mixta (both pteridosperms), herbaceous bisporangiate lycopsid and Hymenotheca sp. (unknown affinity). These species formed small clumps that typically grew between the trunks of arborescent lycopsids, where sunlight was more likely to reach the forest floor. However, many species (e.g., C. angustissima, D. longifolia) were probably also capable of climbing or clinging to upright vegetation, and crept along the forest floor until a suitable support was encountered.

At the time of the volcanic eruption, the majority of species in the mire had reached sexual maturity and many were in a reproductive phase. Evidence suggests that forests forming the Lower Radnice mire were disturbance dominated, with peat accumulation frequently interrupted by spatially random incursions of sediment-laden flood- waters. It may be that peat-forming vegetation was killed off when such perturbations were extreme, leading to the simultaneous recolonisation of open spaces by a single suite of taxa once water levels subsided. In contrast, synchronised reproduction may have resulted from minor disturbances.

\section{Concluding statement}

This analysis has provided a high fidelity reconstruction of a Bolsovian peat-forming mire. Like vegetation preserved in coal balls and roof-shale floras, plant fossil-bearing volcaniclastics overlying or intercalated within coal seams can provide an exceptional source of data on the composition, diversity, spatial distribution, and growth habits of the Pennsylvanian plant communities that formed these spectacular ecosystems. Furthermore, large plant fragments are often found in volcaniclastic horizons, with various organs broken from a parent plant buried around its axis and preserved in a natural association. This information can offer reliable correlation between isolated organs, and help to refine whole-plant reconstructions. The main disadvantage of such tuff beds is their uncommon occurrence or even absence in most Euramerican coalfields. They are generally only found in intramontane basins where volcanic activity was associated with active orogenesis, whereas they are rare in large foreland and cratonic basins distant from volcanic centres.

The most accurate details on Pennsylvanian mire vegetation can only be resolved when the forest has been preserved in a geological instant (a $T^{0}$ deposit), such as in situ burial by volcanic ash as has been documented herein and by others (e.g., Wagner, 1989; Rößler and Barthel, 1998; Pfefferkorn and Wang, 2007; Opluštil et al., 2007; Libertín et al., 2009-this volume). In comparison, plant remains preserved in coal balls are less likely to yield an instantaneous snapshot of vegetation inhabiting a peat-forming mire (Behrensmeyer et al., 2000; Gastaldo et al., 2004b), and accurate estimation of the diversity and biomass contributions of various taxa at any given time slice depends on meticulous, layer-by-layer analysis. Nonetheless, coal balls can be more easily quantified for statistical processing, and their wide stratigraphic and palaeogeographic distribution has provided a more complete picture of the changes in swamp composition through time (Phillips, 1981; Phillips and Peppers, 1984; Phillips et al., 1985). Many roof-shale floras contain parautochthonous or allochthonous remains that have no genetic relationship to the underlying coal seam, even if erect stems are present. Only if a mire has been rapidly drowned due to seismic activity, or quickly covered by sediment due to channel crevassing, can the composition and spatial distribution of plant remains be considered as representative of the former swamp vegetation (Gastaldo et al., 1995, 2004a,b; DiMichele et al., 2007). Hence, in comparison to many roofshale floras, fossiliferous tuff beds are able to provide more reliable and absolute information about the flora that formed the underlying peat.

\section{Acknowledgements}

The excavations and research presented in this paper were primarily supported by grant project No. 205/05/0105 provided by the Grant Agency of the Czech Republic. A minor part of funding was supplied from grant project MSM 0021620855 from the Faculty of Science, Charles University, the Research Program of the Czech Geological Survey (MZP0002579801) and GAČR 205/07/1059 of the West Bohemian Museum in Pilsen. ARB was supported by a Canada Graduate Scholarship from the Natural Sciences and Engineering Research Council of Canada, and through an Izaak Walton Killam Predoctoral Scholarship from Dalhousie University. It is probably a twist of fate that the excavations were situated on land owned by Mr. Zdeněk Sternberg, a distant relative of Count Kaspar Maria Sternberg, a founding father of palaeobotany and an owner of coal mines in this area in the first half of the 19th century. Therefore, we dedicate this palaeobotanical contribution to him. We are also very grateful to Mr. Zdeněk Sternberg and Mr. Jan Suda, who 
provided access to the land and agreed with the excavation works. Mr. Jan Suda is also thanked for providing equipment necessary to carry out the excavations. Finally, we thank W.A. DiMichele (Smithsonian Institution, Washington), and two anonymous referees for their very thoughtful and constructive reviews.

\section{References}

Barthel, M., 1962. Epidermisuntersuchungen an einigen inkohlten Pteridospermenblättern des Oberkarbons und Perms. Geologie, 11, Beiheft 33, 1-140.

Bateman, R.M., 1991. Palaeoecology. In: Cleal, C.J. (Ed.), Plant Fossils in Geological Investigation: The Palaeozoic. Ellis Horwood Series in Applied Geology. Ellis Horwood, New York, pp. 34-116.

Batenburg, L.H., 1982. "Compression species" and "petrifaction species" of Sphenophyllum compared. Review of Palaeobotany and Palynology 36 (3-4), 335-359.

Behrensmeyer, A.K., Kidwell, S.M., Gastaldo, R.A., 2000. Taphonomy and paleobiology. In: Erwin, D.H., Wing, S.L. (Eds.), Deep Time: Paleobiology's Perspective. Paleobiology, vol. 26(4), pp. 103-147 (Supplement)

Bek, J., 1998. Spore populations of some plants of groups Lycophyta, Sphenophyta, Pteridophyta and Progymnospermophyta from the Carboniferous limnic basins of the Czech Republic. PhD Thesis. Academy of Science of the Czech Republic, Prague. (In Czech with English summary)

Boersma, M., 1972. The heterogeneity of the form genus Mariopteris Zeiller: A comparative morphological study with special reference to the frond composition of West-European species. PhD Thesis. Laboratory of Palaeobotany and Palynology, State University, Utrecht. (published by Drukkerij Elinkwijk, Utrecht) (Atlas with plates $1-43$ )

Brongniart, A., 1828. Historie des végétaux fossiles, ou recherches botaniques et géologiques sur les Végétaux renfermés dans les diverses couches du globe 1.1-488 $2,1-72$.

Bronn, H.G., 1835. Lethea Geognostica 1 (1835), p. 672 Stuttgart.

Brousmiche-Delcambre, C., Coquel, R., Wagner, R.H., 1995. Nouvelle interprétation du genre Omphalophloios White, 1898 (Lycophyte primitive). Comptes Rendus de l'Académie des Sciences, Série II. Sciences de la Terre et des Planetes 321 (2), 179-184.

Cain, S.A., 1938. The species-area curve. American Midland Naturalist 19, 573-581.

Calder, J.H., 1993. The evolution of a ground-water-influenced (Westphalian B) peat-forming ecosystem in a piedmont setting: the No. 3 Seam, Springhill Coalfield, Cumberland Basin, Nova Scotia. In: Cobb, J.C., Cecil, C.B. (Eds.), Modern and Ancient Coal-forming Environments. Geological Society of America Special Paper, vol. 286, pp. 153-180.

Calder, J.H., Gibling, M.R., Scott, A.C., Davies, S.J., Hebert, B.L., 2006. A fossil lycopsid forest succession in the classic Joggins section of Nova Scotia: paleoecology of a disturbance-prone Pennsylvanian wetland. In: Greb, S.F., DiMichele, W.A. (Eds.) Wetlands through Time. Geological Society of America Special Paper, vol. 399, pp. 169-195.

Cleal, C.J., Shute, C.H., Zodrow, E.L., 1990. A revised taxonomy for palaeozoic Neuropteric foliage. Taxon 39, 486-589.

Cleal, C.J., 1991. Introduction. In: Cleal, C.J. (Ed.), Plant Fossils in Geological Investigation: The Palaeozoic. . Ellis Horwood Series in Applied Geology. Ellis Horwood, New York, pp. 13-33.

Costanza, S.H., 1985. Pennsylvanioxylon of Middle and Upper Pennsylvanian coals from the Illinois Basin and its comparison with Mesoxylon. Palaeontographica, Abteilung B: Palaeophytologie 197 (4-6), 81-121.

DiMichele, W.A., 1979a. Arborescent lycopods of Pennyslvanian age coals: Lepidodendron dicentricum C. Felix. Palaeontographica, Abteilung B: Palaeophytologie 171 (4-6), 122-136.

DiMichele, W.A., 1979b. Arborescent lycopods of Pennsylvanian age coals: Lepidophloios. Palaeontographica, Abteilung B: Palaeophytologie 171 (1-3), 57-77.

DiMichele, W.A., 1980. Paralycopodites Morey \& Morey, from the Carboniferous of Euramerica - a reassessment of generica affinities and evolution of "Lepidodendron" brevifolium Williamson. American Journal of Botany 67 (10), 1466-1476.

DiMichele, W.A., 1985. Diaphorodendron, gen. nov., a segregate from Lepidodendron (Pennsylvanian age). Systematic Botany 10 (4), 453-458.

DiMichele, W.A., Bateman, R.M., 1992. Diaphorodendraceae, fam. nov. (Lycopsida: Carboniferous): systematics and evolutionary relationships of Diaphorodendron and Synchysidendron, gen. nov. American Journal of Botany 79 (6), 605-617.

DiMichele, W.A., DeMaris, P.J., 1987. Structure and dynamics of a Pennsylvanian-age Lepidodendron forest: colonizers of a disturbed swamp habitat in the Herrin (no. 6) coal of Illinois. Palaios 2 (2), 146-157.

DiMichele, W.A., Nelson, W.J., 1989. Small-scale spatial heterogeneity in Pennsylvanian-age vegetation from the roof shale of the Springfield Coal (Illinois Basin). Palaios 4 (3), 276-280.

DiMichele, W.A., Phillips, T.L., 1985. Arborescent lycopod reproduction and paleoecology in a coal-swamp environment of late Middle Pennsylvanian age (Herrin Coal, Illinois, U.S.A.). Review of Palaeobotany and Palynology 44 (1-2), 1-26.

DiMichele, W.A., Phillips, T.L., 1988. Paleoecology of the Middle Pennsylvanian-age Herrin coal swamp (Illinois) near a contemporaneous river system, the Walshville paleochannel. Review of Palaeobotany and Palynology 56 (1-2), 151-176.

DiMichele, W.A., Phillips, T.L., 1994. Paleobotanical and paleoecological constraints on models of peat formation in the Late Carboniferous of Euramerica. Palaeogeography, Palaeoclimatology, Palaeoecology 106 (1-4), 39-90.

DiMichele, W.A., Phillips, T.L., 1996. Climate change, plant extinctions, and vegetationa recovery during the Middle-Late Pennsylvanian transition: the case of tropical peatforming environments in North America. In: Hart M.L. (Ed.), Biotic Recovery from Mass Extinction Events. Geological Society Special Publication, vol. 102, pp. 201-221.
DiMichele, W.A., Phillips, T.L., 2002. The ecology of Paleozoic ferns. Review of Palaeobotany and Palynology 119 (1-2), 143-159.

DiMichele, W.A., Eble, C.F., Chaney, D.S., 1996. A drowned lycopsid forest above the Mahoning coal (Conemaugh Group, Upper Pennsylvanian) in eastern Ohio, U.S.A. International Journal of Coal Geology 31 (1-4), 249-276.

DiMichele, W.A., Phillips, T.L., Nelson, W.J., 2002. Place vs. time and vegetational persistence: a comparison of four tropical mires from the Illinois Basin during the height of the Pennsylvanian Ice Age. International Journal of Coal Geology 50 (1-4), 43-72.

DiMichele, W.A., Phillips, T.L., Pfefferkorn, H.W., 2006. Paleoecology of Late Paleozoic pteridosperms from tropical Euramerica. Journal of the Torrey Botanical Society 133 (1), 83-118.

DiMichele, W.A., Falcon-Lang, H.J., Nelson, W.J., Elrick, S.D., Ames, P.R., 2007. Ecological gradients within a Pennsylvanian mire forest. Geology 35 (5), 415-418.

Drábková, J., 1986. Litologická a palynologická charakteristika karbonských sedimentů na Dole Pokrok - Přívětice. MS Thesis. Faculty of Sciences, Charles University, Prague.

Drábková, J., Bek, J., Opluštil, S., 2004. The first compression fossils of Spencerites (Scott) emend., and its isospores, from the Bolsovian (Pennsylvanian) of the KladoRakoník and Radnice basins, Czech Republic. Review of Palaeobotany and Palynology 130 (1-4), 59-88.

Eble, C.F., Grady, W.C., 1993. Palynologic and petrographic characteristics of two Middle Pennsylvanian coal beds and a probable modern analogue. In: Cobb, J.C., Cecil, C.B. (Eds.), Modern and Ancient Coal-forming Environments. Geological Society of America Special Paper, vol. 286, pp. 119-138.

Falcon-Lang, H.J., 2005. Small cordaitalean trees in a marine-influenced coastal habitat in the Pennsylvanian Joggins Formation, Nova Scotia. Journal of the Geological Society, London 162 (3), 485-500.

Falcon-Lang, H.J., 2006. Latest Mid-Pennsylvanian tree-fern forests in retrograding coastal plain deposit, Sydney Mines Formation, Nova Scotia, Canada. Journal of the Geological Society, London 163 (1), 81-93.

Galtier, J., 1997. Coal-ball floras of the Namurian-Westphalian of Europe. Review of Palaeobotany and Palynology 95 (1-4), 51-72.

Galtier, J., 2004. A new zygopterid fern from the Early Carboniferous of France and a reconsideration of the Corynepteris-Alloiopteris ferns. Review of Palaeobotany and Palynology 128 (3-4), 195-217.

Gastaldo, R.A., 1986. Implications on the paleoecology of autochthonous lycopods in clastic sedimentary environments of the Early Pennsylvanian of Alabama. Palaeogeography, Palaeoclimatology, Palaeoecology 53 (2-4), 191-212.

Gastaldo, R.A., 1987. Confirmation of Carboniferous clastic swamp communities. Nature 326, 869-871.

Gastaldo, R.A., 1988. A conspectus of phytotaphonomy. In: DiMichele, W.A., Wing, S.L. (Eds.), Methods and Applications of Plant Paleoecology: Notes for a Short Course. The Paleontological Society Special Publication, vol. 3, pp. 14-28.

Gastaldo, R.A., 1994. The genesis and sedimentation of phytoclasts with examples from coastal environments. In: Traverse, A. (Ed.), Sedimentation of Organic Particles. Cambridge University Press, Cambridge, pp. 103-127.

Gastaldo, R.A., Staub, J.R., 1999. A mechanism to explain the preservation of leaf litters in coals derived from raised mires. Palaeogeography, Palaeoclimatology, Palaeoecology $149(1-4), 1-14$.

Gastaldo, R.A., Pfefferkorn, H.W., DiMichele, W.A., 1995. Taphonomic and sedimentologic characterization of roof-shale floras. In: Lyons, P.C., Morey, E.D., Wagner, R.H. (Eds.), Historical Perspectives of Early Twentieth Century Carboniferous Paleobotany in North America (W.C. Darrah volume). Geological Society of America Memoir, vol. 185, pp. 341-352.

Gastaldo, R.A., Stevanović-Walls, I.M., Ware, W.N., 2004a. In situ, erect forests are evidence for large-magnitude, coseismic base-level changes within Pennsylvanian cyclothems of the Black Warrior Basin, USA. In: Pashin, J.C., Gastaldo, R.A. (Eds.), Sequence Stratigraphy, Paleoclimate, and Tectonics of Coal-Bearing Strata, vol. 51. American Association of Petroleum Geology Studies in Geology, pp. 219-238.

Gastaldo, R.A., Stevanović-Walls, I.M., Ware, W.N., Greb, S.F., 2004b. Community heterogeneity of Early Pennsylvanian peat mires. Geology 32 (8), 693-696.

Gradziński, R., Doktor, M., 1995. Upright stems and their burial conditions in the coalbearing Mudstone Series (Upper Carboniferous), Upper Silesia Coal Basin, Poland. Studia Geologica Polonica 108, 129-147.

Hess, J.C., Lippolt, H.J., Holub, V.M., Pešek, J., 1985. Isotopic ages of two Westphalian C tuffs a contribution to the Upper Carboniferous time scale. Terra Cognita 5, 236-237.

Janzen, D.H., 1969. Seed-eaters versus seed size, number, toxicity and dispersal. Evolution 23 (1), 1-27.

Janzen, D.H., 1971. Seed predation by animals. Annual Review of Ecology and Systematics $2,465-492$

Jentsch, A., 2004. Disturbance driven vegetation dynamics. Concepts from biogeography to community ecology, and experimental evidence from dry acidic grasslands in central Europe. Dissertationes Botanicae 384, 1-218.

Kidston, R., 1909. Les végétaux houillers recueillis dans le Hainaut Belge et se trouvant dans les Collections du Musée Royal d’Histoire naturalle à Bruxelles. Mémoires du Musée de Royal d’Histoire Naturelle de Belgique 4, 137-138.

Klusemann, H., Teichmüller, R., 1954. Begrabene Wälder im Ruhrkohlenbecken. Natur und Volk 84 (11), 373-382.

Krings, M., Kerp, H., Taylor, T.N., Taylor, E.L., 2003. How Paleozoic vines and lianas got off the ground: on scrambling and climbing Carboniferous-Early Permian pteridosperms. The Botanical Review 69 (2), 204-224.

Krings, M., Taylor, T.N., Taylor, E.L., Axsmith, B.J., Kerp, H., 2001. Cuticles of Mariopteris occidentalis White nov. emend. from the Middle Pennsylvanian of Oklahoma (USA), and a new type of climber hook for mariopteroid pteridosperms. Review of Palaeobotany and Palynology 114 (3-4), 209-222. 
Lindley, J., Hutton, W. 1831. The fossil flora of Great Britain, I.

Lesnikowska, A.D., 1989. Anatomically preserved Marattiales from coal swamps of the Desmoinesian and Missourian of the mid-continent United States: Systematics, ecology, and evolution. PhD thesis, University of Illinois, Urbana-Champaign.

Libertín, M., Bek, J., Drábková, J., 2008. Two new Carboniferous fertile sphenophylls and their spores from the Czech Republic. Acta Palaeontologica Polonica 53 (4), 723-732.

Libertín, M., Opluštil, S., Pšenička, J., Bek, J., Sýkorová, I., Dašková, J., 2009. Middle Pennsylvanian pioneer plant assemblage buried in situ by volcanic ash-fall, central Bohemia, Czech Republic. Review of Palaeobotany and Palynology 155, 204-233 (this volume). doi:10.1016/j.revpalbo.2007.12.012.

Lyons, P.C., Zodrow, E.L., Millay, M.A., Dolby, G., Gillis, K.S., Cross, A.T., 1997. Coal-ball floras of Maritime Canada and palynology of the Foord seam: geologic paleobotanical and paleoecological implications. Review of Palaeobotany and Palynology 95 (1-4), 31-50.

Mašek, J., 1973. Vulkanické produkty středočeského karbonu [Volcanic products of the Central Bohemian Carboniferous]. Sborník geologických věd. Geologie 24, 73-104 (In Czech with English abstract).

Moravec, J., Jeník, J., Kolbek, J., Krahulec, F., Husová, M., Květ, J., Neuhäuslová-Novotná, Z., Neuhäusl, R., Blažková, D., Krečmer, V., Kropáč, J., Samek, V., Štěpán, J., 1994. Fytocenologie. Academia, Prague.

Morgan, J., 1959. The morphology and anatomy of American species of the genus Psaronius. Illinois Biological Monographs 27,1-108.

Mueller-Dombois, D., Ellenberg, H., 1974. Aims and Methods of Vegetation Ecology. John Wiley and Sons, New York.

Němejc, F., 1938. The Sphenopterides of the coal basins in Central Bohemia (II part). Palaeontographica Bohemiae 16,1-32.

Novik, E.O., 1947. Classification of Carboniferous pteridospermae (in Russian). Dokl. A.N. SSSR 58 (2), 277-279.

Němejc, F., 1947. Lepidodendraceae středočeských uhelných pánví (Předběžná studie) [The Lepidodendraceae of the coaldistricts of Central Bohemia (A preliminary study)]. Sborník Národního Musea v Praze, řada B, př́írodovědecká. Geologia et Palaeontologia 3B (2), 45-87 (In English with Czech summary).

Newhall, C.G., Self, S., 1982. The Volcanic Explosivity Index (VEI): An estimate of explosive magnitude for historical volcanism. Journal of Geophysical Research 87 (C2), $1231-1238$.

Niklas, K.J., 1994. Predicting the height of fossil plant remains: an allometric approach to an old problem. American Journal of Botany 81 (10), 1235-1242.

Oliver, C.D., Larson, B.C., 1990. Forest Stand Dynamics. McGraw-Hill, New York.

Opluštil, S., 2005a. Evolution of the Middle Westphalian river valley drainage system in central Bohemia (Czech Republic) and it palaeogeographic implication. Palaeogeography, Palaeoclimatology, Palaeoecology 222 (3-4), 223-258.

Opluštil, S., 2005b. The effect of paleotopography, tectonics and sediment supply on quality of coal seams in continental basins of central and western Bohemia (Westphalian), Czech Republic. International Journal of Coal Geology 64 (3-4), 173-203.

Opluštil, S., Pšenička, J., Libertín, M., Šimůnek, Z., 2007. Vegetation patterns of Westphalian and Lower Stephanian mire assemblages preserved in tuff beds of the continental basins of Czech Republic. Review of Palaeobotany and Palynology 143 (3-4), 107-154.

Potonié, H., 1891. Über einige Carbonfarne, II. Jahrbuch K. Preuss. Geol. L.A. für 1890, 11-39.

Potonié, H., 1892. Über einige Carbonfarne, III. Jahrbuch K. Preuss. Geol. L.A. für 1891, $1-36$.

Pešek, J., 1994. Carboniferous of Central and Western Bohemia (Czech Republic). Czech Geological Survey, Prague.

Pfefferkorn, H.W., Wang, J., 2007. Early Permian coal-forming floras preserved as compressions from the Wuda District (Inner Mongolia, China). International Journal of Coal Geology 69 (1-2), 90-102.

Phillips, T.L., 1980. Stratigraphic and geographic occurrences of permineralised coalswamp plants - Upper Carboniferous of North America and Europe. In: Dilcher, D.L., Taylor, T.N. (Eds.), Biostratigraphy of Fossil Plants. Dowden, Hutchinson and Ross, Stroudsburg, pp. 25-92.

Phillips, T.L., 1981. Stratigraphic occurrences and vegetational patterns of Pennsylvanian pteridosperms in Euramerican coal swamps. Review of Palaeobotany and Palynology 32 (1), 5-26.

Phillips, T.L., DiMichele, W.A., 1981. Paleoecology of the Middle Pennsylvanian age coal swamps in southern Illinois: Herrin Coal Member at Sahara Mine No. 6. In: Niklas, K.J. (Ed.), Paleobotany, Paleoecology, and Evolution. Praeger Scientific Publishers, New York, pp. 231-285.

Phillips, T.L., DiMichele, W.A., 1992. Comparative ecology and life-history biology of arborescent lycopsids in Late Carboniferous swamps of Euramerica. Annals of the Missouri Botanical Garden 79 (3), 560-588.

Phillips, T.L., Galtier, J., 2005. Evolutionary and ecological perspectives of Late Paleozoic ferns. Part I. Zygopteridales. Review of Palaeobotany and Palynology 135 (3-4), 165-203.

Phillips, T.L., Peppers, R.A., 1984. Changing patterns of Pennsylvanian coal-swamp vegetation and implications of climate control on coal occurrence. International Journal of Coal Geology 3 (3), 205-255.

Phillips, T.L., Kunz, A.B., Mickish, D.J., 1977. Paleobotany of permineralized peat (coal balls) from the Herrin (No. 6) Coal Member of the Illinois Basin. In: Given, P.N., Cohen, D. (Eds.), Interdisciplinary Studies of Peat and Coal Origins, vol. 7. Geological Society of America Microform Publication, pp. 18-49.

Phillips, T.L., Peppers, R.A., DiMichele, W.A., 1985. Stratigraphic and interregional changes in Pennsylvanian coal-swamp vegetation: Environmental inferences. International Journal of Coal Geology 5 (1-2), 43-109.

Pryor, J.S., Gastaldo, R.A., 2000. Paleoecological analysis of two Early Pennsylvanian mineral-substrate wetlands. Palaios 15 (1), 3-13.
Pšenička, J., 2006. Taphonomy and characteristic of Corynepteris angustissima (Sternberg) Nemejc from volcanic ash of the Whetstone Horizon (Bolsovian) in central and western Bohemia, Czech Republic. Program and Abstracts, 7th European Palaeobotany-Palynology Conference. National Museum, Prague, pp. 109-110.

Raymond, A., 1988. The paleoecology of a coal-ball deposit from the Middle Pennsylvanian of Iowa dominated by cordaitalean gymnosperms. Review of Palaeobotany and Palynology 53 (3-4), 233-250.

Rößler, R., 2000. The late Palaeozoic tree fern Psaronius - an ecosystem unto itself Review of Palaeobotany and Palynology 108 (1-2), 55-74.

Rößler, R., 2001. Der versteinerte Wald von Chemnitz. Katalog zur Ausstellung Sterzeleanum. Museum für Naturkunde, Chemnitz.

Rößler, R., Barthel, M., 1998. Rotliegend taphocoenoses preservation favoured by rhyolithic explosive volcanism. Freiberger Forschungshefte, Paläontologie, Stratigraphie, Fazies C 474(6), 59-101.

Sternberg, K., 1821. Versuch einer geognostich botanischen Darstellung der Flora der Vorwelt. 1 (2), 1-33.

Sternberg, K., 1825. Versuch einer geognostich botanischen Darstellung der Flora der Vorwelt. 1 (4), 1-48.

Schimper, W., 1869. Traité de Paléontologie végétales. 1-738.

Stur, D.R., 1885. Die Carbonflora der Schatzlarer Schichten. Abh. D. k.k. geol. Landesanstalt. Wien. Bh. XI., 418 pp.

Scott, A.C., 1977. A review of the ecology of Upper Carboniferous plant assemblages, with new data from Strathclyde. Palaeontology 20 (2), 447-473.

Scott, A.C., 1978. Sedimentological and ecological control of Westphalian B plant assemblages from West Yorkshire. Proceedings of the Yorkshire Geological Society 41 (4), 461-508.

Scott, A.C., 1979. The ecology of Coal Measure floras from northern Britain. Proceedings of the Geologists' Association 90, 97-116.

Scott, A.C., Rex, G., 1985. The formation and significance of Carboniferous coal balls. Philosophical Transactions of the Royal Society of London B 311,123-137.

Scott, A.C., Mattey, D.P., Howard, R., 1996. New data on the formation of Carboniferous coal balls. Review of Palaeobotany and Palynology 93 (1-4), 317-331.

Shute, C.H., Cleal, C.L., 2002. Ecology and growth habit of Laveineopteris: a gymnosperm from the Late Carboniferous tropical rain forests. Palaeontology 45 (5), 943-972.

Spicer, R.A., 1989. The formation and interpretation of plant fossil assemblages Advances in Botanical Research 16, 95-191.

Steward, W.N., Delevoryas, T., 1956. The medullosan pteridosperms. Botanical Review $22,45-80$.

Stidd, B.M., Phillips, T.L., 1982. Johnhallia lacunosa gen. et sp. n.: a new pteridosperm from the Middle Pennsylvanian of Indiana. Journal of Paleontology 56 (5), 1093-1102.

Thomas, B.A., 1997. Upper Carboniferous herbaceous lycopsids. Review of Palaeobotany and Palynology 95 (1-4), 129-153.

Thomas, B.A., Watson, J., 1976. A rediscovered 114-foot Lepidodendron from Bolton, Lancashire. Geological Journal 11 (1), 15-20.

Tian, Baolin, Wang, Shi-Jun, Guo, Ying-Ting, Chen, Gui-Ren, Zhao, Hong, 1996. Flora of Palaeozoic coal balls of China. The Palaeobotanist 45, 247-254

Turek, V., 1989. Fish and amphibian trace fossils from Westphalian sediments of Bohemia. Palaeontology 32 (3), 623-643.

Turek, V., 1996. Fish trace fossil interpreted as a food gathering swimming trail from the Upper Carboniferous (Westphalian) of Bohemia. Časopis Národního Muzea, Řada prírodovědná 165 (1-4), 5-8.

Unger, F., 1850. Genera et species plantarum fossilium. Vindobonae, 1850.

Wagner, R.H., 1989. A late Stephanian forest swamp with Sporangiostrobus fossilized by volcanic ash fall in the Puertollano Basin, central Spain. International Journal of Coal Geology 12 (1-4), 523-552.

Weiss, Ch.E., 1884. Beiträge zur fossilen Flora. III. Steinkohlen-Calamarien. II. Abhandlungen zur geologischen Specialkarte von Preussen und den Thüringischen Staaten 5(2), 1-204. Atlas, plates I-XXVIII.

Weithofer, K.A., 1896. Die geologischen Verhältnisse des Bayer-Schachtes und des benachbarten Theiles der Pilsner Kohlenmulde. Österreichische Zeitschrift für Berg- und Hüttenwesen 44(25-28), 317-321, 331-335, 345-349, 355-357.

Weithofer, K.A., 1902. Geologische Skizze des Kladno - Rakonitzer Kohlenbeckens Verhandlunger der Kaiserlich-königlischen Geologischen Reichsanstalt, 399-420.

White, P.S., Pickett, S.T.A., 1985. Natural disturbance and patch dynamics, an introduction. In: Pickett, S.T.A., White, P.S. (Eds.), The Ecology of Natural Disturbance and Patch Dynamics. Academic Press, New York, pp. 3-13.

Whitmore, T.C., 2006. An Introduction to Tropical Rain Forests. Oxford University Press, Oxford.

Willard, D.A., 1993. Vegetational patterns in the Springfield Coal (Middle Pennsylvanian, Illinois Basin): comparison of miospores and coal-ball records. In: Cobb, J.C. Cecil, C.B. (Eds.), Modern and Ancient Coal-Forming Environments. Geological Society of America Special Paper, vol. 286, pp. 139-152.

Winston, R.B., 1988. Paleoecology of Middle Pennsylvanian age peat-swamps in Herrin Coal, Kentucky, U.S.A. International Journal of Coal Geology 10 (3), 203-238.

Wnuk, C., 1985. The ontogeny and paleoecology of Lepidodendron rimosum and Lepidodendron bretonense trees from the Middle Pennsylvanian of the Bernice Basin (Sullivan County, Pennsylvania). Palaeontographica, Abteilung B: Palaeophytologie 195 (5-6) 153-181.

Wnuk, C., Pfefferkorn, H.W., 1984. The life habits and paleoecology of Middle Pennsylvanian medullosan pteridosperms based on an in situ assemblage from the Bernice Basin (Sullivan County, Pennsylvania, U.S.A.). Review of Palaeobotany and Palynology 41 (3-4), 329-351.

Zeiller, R., 1879. Végétaux fossiles du terrain houiller de la France. Mémoires pour servir à l'explication de la carte géologique détaillée de la France. 4 (2), 1-186. 